c.3

US Army Corps

of Engineers

Waterways Experiment

Station

\title{
In Situ Geophysical Investigation to Evaluate Dynamic Soil Properties at Success Dam, California
}

by José L. Llopis, Landris T. Lee, WES

Russell A. Green, Defense Nuclear Facilities Safety Board

US-CE-C Property of the

United States Government

\author{
Russell A. Green, Defense Nuclear Facilities Safety Board
}

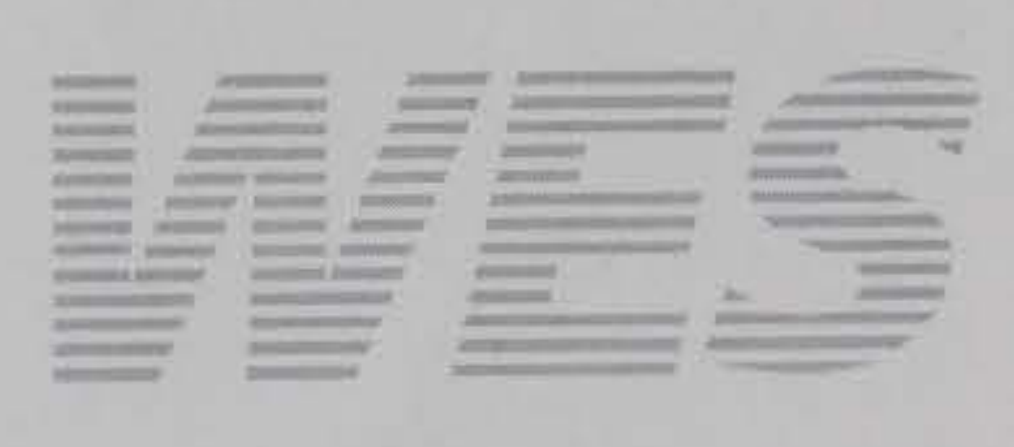

Approved For Public Release; Distribution Is Unlimited

Research Library

US Army Engineer Waterways

Experiment Station

Vicksburg. Mississippi

Prepared for U.S. Army Engineer District, Sacramento 


\section{In Situ Geophysical Investigation to Evaluate Dynamic Soil Properties at Success Dam, California}

by José L. Llopis, Landris T. Lee

U.S. Army Corps of Engineers

Waterways Experiment Station

3909 Halls Ferry Road

Vicksburg, MS 39180-6199

Russell A. Green

Defense Nuclear Facilities Safety Board

625 Indiana Avenue, N.W., Suite 700

Washington, DC 20004

Final report

Approved for public release; distribution is unlimited 


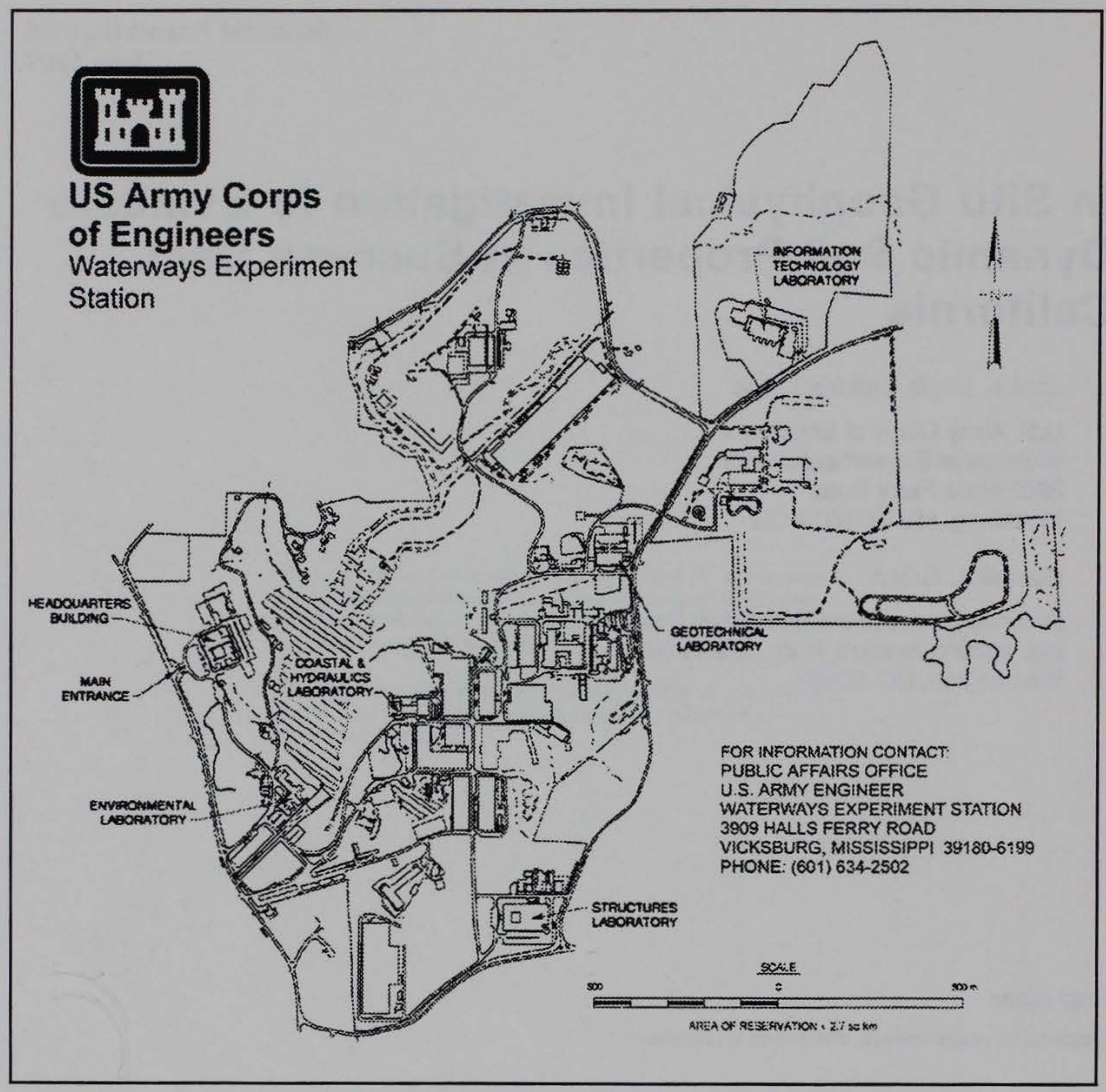

\section{Waterways Experiment Station Cataloging-in-Publication Data}

\section{Llopis, Jose L.}

In situ geophysical investigation to evaluate dynamic soil properties at Success Dam, California / by Jose L. Llopis, Landris T. Lee, Russell A. Green; prepared for U.S. Army Engineer District, Sacramento.

98 p. : ill. ; $28 \mathrm{~cm}$. - (Technical report ; GL-97-8)

Includes bibliographic references.

1. Shear waves. 2. Success Dam (Calif.) 3. Soil Dynamics - California - Porterville. 4. Geophysics - California - Testing. I. Lee, Landris T. II. Green, Russell A. III. United States. Army. Corps of Engineers. Sacramento District. IV. U.S. Army Engineer Waterways Experiment Station. V. Geotechnical Laboratory (U.S. Army Engineer Waterways Experiment Station) VI. Title. VII. Series: Technical report (U.S. Army Engineer Waterways Experiment Station); GL-97-8.

TA7 W34 no.GL-97-8 


\section{Contents}

Preface $\ldots \ldots \ldots \ldots \ldots \ldots \ldots \ldots \ldots \ldots \ldots \ldots \ldots \ldots$

Conversion Factors, Non-SI to SI Units of Measurement $\ldots \ldots \ldots \ldots \ldots$ vi

1-Introduction $\ldots \ldots \ldots \ldots \ldots \ldots \ldots \ldots \ldots \ldots \ldots \ldots \ldots \ldots \ldots$

Background $\ldots \ldots \ldots \ldots \ldots \ldots \ldots \ldots \ldots \ldots \ldots \ldots \ldots \ldots \ldots$

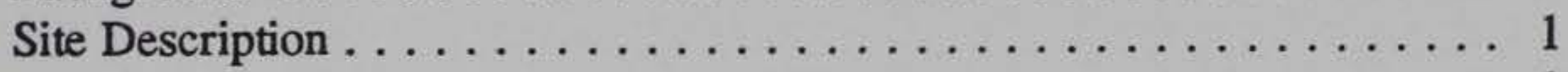

Test Program . . . . . . . . . . . . . . . . . 1

Upstream service road $\ldots \ldots \ldots \ldots \ldots \ldots \ldots \ldots \ldots \ldots \ldots \ldots \ldots \ldots$

Downstream service road $\ldots \ldots \ldots \ldots \ldots \ldots \ldots \ldots \ldots$

Downstream toe $\ldots \ldots \ldots \ldots \ldots \ldots \ldots \ldots \ldots \ldots \ldots \ldots \ldots$

2-Test Principles and Procedures $\ldots \ldots \ldots \ldots \ldots \ldots \ldots \ldots \ldots$

Crosshole Tests $\ldots \ldots \ldots \ldots \ldots \ldots \ldots \ldots \ldots \ldots \ldots \ldots$

Test boring installation $\ldots \ldots \ldots \ldots \ldots \ldots \ldots \ldots \ldots \ldots \ldots \ldots$

Borehole deviation surveys $\ldots \ldots \ldots \ldots \ldots \ldots \ldots \ldots$

Crosshole testing $\ldots \ldots \ldots \ldots \ldots \ldots \ldots \ldots \ldots \ldots \ldots \ldots \ldots \ldots \ldots$

Downhole Geophysical Logging $\ldots \ldots \ldots \ldots \ldots \ldots \ldots \ldots$

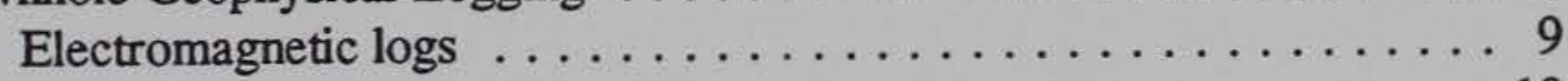

Gamma logs . . . . . . . . . . . . . . . . 10

Geophysical logging procedures $\ldots \ldots \ldots \ldots \ldots \ldots \ldots \ldots \ldots$

Surface Seismic Refraction . . . . . . . . . . . . . . 11

Chronology of Geophysical Investigations $\ldots \ldots \ldots \ldots \ldots \ldots \ldots \ldots \ldots \ldots$

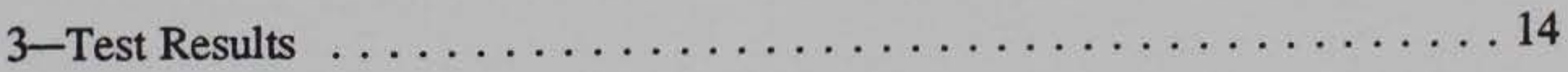

Crosshole Tests . . . . . . . . . . . . . . . . . . . 14

Upstream service road . . . . . . . . . . . . . . . . 14

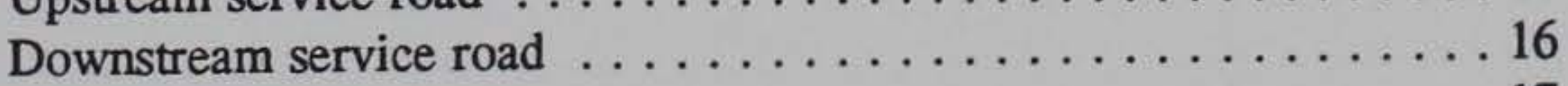

Downstream toe ........................ 17

Downhole Geophysical Logs $\ldots \ldots \ldots \ldots \ldots \ldots \ldots \ldots \ldots$

Upstream service road $\ldots \ldots \ldots \ldots \ldots \ldots \ldots \ldots \ldots \ldots$

Downstream service road $\ldots \ldots \ldots \ldots \ldots \ldots \ldots \ldots \ldots \ldots \ldots$

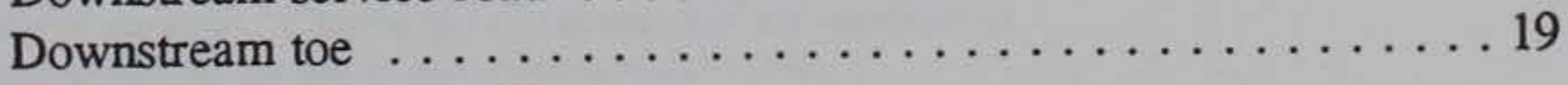


Surface Seismic Refraction $\ldots \ldots \ldots \ldots \ldots \ldots$

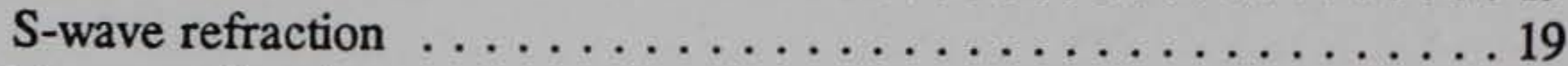

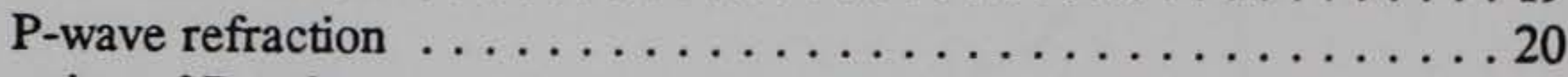

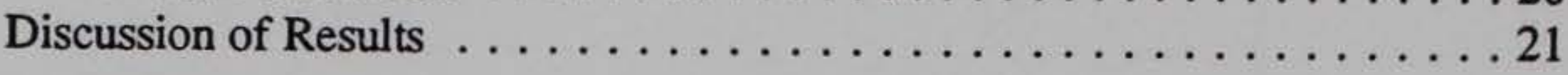

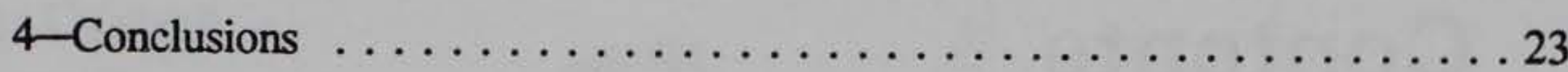

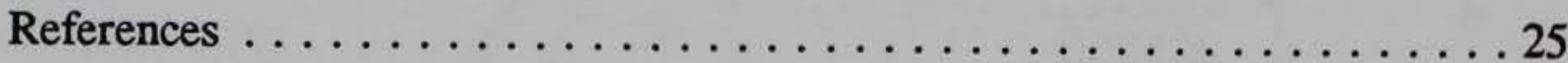

Figures 1-61

SF298 


\section{Preface}

An in situ geophysical investigation was conducted by personnel of the U.S. Army Engineer Waterways Experiment Station (WES) at Success Dam, Porterville, CA, during the periods 29 April to 4 May 1994, 15 to 24 May 1994, 7 to 12 February 1995, and 9 to 10 May 1995. The work was performed for the U.S. Army Engineer District, Sacramento (SPK). The SPK Project Engineer was Mr. John Nickell. The work was funded under MIPR CESPK-ED-94-10 dated 17 February 1994.

This report was prepared by Messrs. José L. Llopis and Landris T. Lee, Engineering Geophysics Branch (EGB), Earthquake Engineering and Geosciences Division (EEGD), Geotechnical Laboratory (GL), WES, and Mr. Russell A. Green, Defense Nuclear Facilities Safety Board. The work was performed under the direct supervision of Mr. Joseph R. Curro, Jr., Chief, EGB, and under the general supervision of Drs. A. G. Franklin, Chief, EEGD, and William F. Marcuson III, Director, GL.

At the time of publication of this report, Director of WES was Dr. Robert W. Whalin. Commander was COL Bruce K. Howard, EN.

The contents of this report are not to be used for advertising, publication, or promotional purposes. Citation of trade names does not constitute an official endorsement of the use of such commercial products. 


\section{Conversion Factors, Non-SI to SI Units of Measurement}

Non-Si units of measurement used in this report can be converted to SI units as follows:

\begin{tabular}{||l|l|l||}
\hline Multiply & By & To Obtain \\
\hline degrees (angle) & 0.01745329 & radians \\
\hline feet & 0.3048 & meters \\
\hline gallons & 3.785412 & cubic decimeters \\
\hline inches & 2.54 & centimeters \\
\hline miles (US statute) & 1.609347 & kilometers \\
\hline millimhos per foot & 3.28 & millimhos per meter \\
\hline pounds (force) & 4.448222 & newtons \\
\hline tons per square foot & 95.76052 & kilopascals \\
\hline
\end{tabular}




\section{Introduction}

\section{Background}

Current computerized seismic wave propagation analysis procedures for dams and foundations require values of shear-wave (S-wave) propagation velocities to be determined as a function of depth. The $\mathrm{S}$-wave velocities are used in conjunction with conventional field and laboratory soil testing methods to provide soil property values for earthquake analysis of the dam and foundation.

\section{Site Description}

Success Dam is located on the Tule River approximately six miles east of the town of Porterville, California, as shown in Figure 1. The dam, completed in 1961 , is a zoned earth-fill structure with a crest length of $3404 \mathrm{ft}$ and a maximum height of $145 \mathrm{ft}$. The zones consist of a central impervious core, transition sections, and random-fill shells. The impervious core trench was founded on weathered rock on the right abutment and on weathered rock and older alluvium in the valley section and left abutment. Depths of excavation for the core trench ranged from 4 to $57 \mathrm{ft}$. The less impervious older alluvium is a heterogeneous assemblage of river-deposited silt, clay, sand, gravel, cobbles, and boulders intermixed with slope wash and talus from the bordering hills. The materials comprising the foundation for the embankment consist of slope wash, alluvial fan deposits, recent alluvial deposits, and terrace deposits. In general, they range from unconsolidated sandy gravels to well consolidated gravelly, sandy clays. A plan view of the dam is shown in Figure 2. Transverse and longitudinal cross sections are presented in Figure 3 and 4 , respectively.

\section{Test Program}

At the request of U.S. Army Engineer District, Sacramento (SPK), personnel of the U.S. Army Engineer Waterways Experiment Station (WES) conducted a geophysical investigation at Success Dam to determine the S-wave velocities of the dam and foundation materials and to delineate the dam-foundation and geologic contacts. The SPK-WES finalized test program consisted of crosshole Swave testing, surface seismic compression-wave ( $\mathrm{P}$-wave) and $\mathrm{S}$-wave refraction 
testing, and borehole geophysical logging. In addition to the geophysical tests, SPK personnel also contracted to have Becker hammer penetration tests performed to estimate equivalent $\left(\mathrm{N}_{1}\right)_{60}$ values. Becker hammer penetration tests were also performed between borings of several crosshole sets used for S-wave testing, to determine the influence of Becker hammer testing on the S-wave velocities of the soils in the immediate vicinity.

The borehole sets used in this investigation were located along service roads on the upstream and downstream slope and along the downstream toe of the dam. The location of the borehole sets used to conduct the S-wave tests and geophysical logs and the layout of the seismic refraction lines are shown in Figure 2. The elevations, depths, and coordinates for each boring are presented in Table 1.

\section{Upstream service road}

Four boring sets, designated as sets GP01, GP06, GP02, and GP07, were used for testing along the upstream service road as shown in Figure 2. Boring set GP01 is located at approximate Sta. $28+80$ and consists of three in-line borings located about $15 \mathrm{ft}$ apart. The borings are designated, from west to east, as GP01A, GP01B, and GP01C. The boring elevations, depths, and coordinates for set GP01 are presented in Table 1. These borings were drilled to a depth of approximately $130 \mathrm{ft}$, thus penetrating the upstream random fill and alluvial foundation materials. However, because of drilling difficulties, GP01A was drilled to a depth of only approximately $90 \mathrm{ft}$.

Boring set GP06 is located near Sta. $31+70$ as shown in Figure 2 and consists of three in-line borings spaced approximately $15 \mathrm{ft}$ apart. The borings are designated, from west to east, as GP06A, GP06B and GP06C. The boring elevations, depths, and coordinates for set GP06 are presented in Table 1. These borings were designed to penetrate the upstream random fill and alluvial foundation materials.

Boring set GP02 consists of two borings spaced $15 \mathrm{ft}$ apart and are located at approximate Sta. $33+10$ as shown in Figure 2. The western and eastern borings are designated GP02A and GP02B, respectively. The original drilling plan called for the installation of three 135 - $\mathrm{ft}$ deep borings however, because of drilling difficulties GP02A was drilled to a depth of only $40 \mathrm{ft}$. Boring GP02B passed through the upstream random fill and into the alluvial foundation materials whereas, GP02A partially penetrated the upstream random fill material. The boring elevations, depths, and coordinates for set GP02 are presented in Table 1.

Boring set GP07 is located near Sta. $37+80$ as shown in Figure 2 and consists of three in-line borings spaced approximately $15 \mathrm{ft}$ apart. The borings are designated, from west to east, as GP07A, GP07B and GP07C. The boring elevations, depths, and coordinates for set GP07 are presented in Table 1. These borings were designed to penetrate the upstream random fill and alluvial foundation materials. 


\section{Downstream service road}

Three boring sets, located on the downstream service road, were used for testing. The three boring sets, from west to east, are designated as sets GP03, GP04, and GP10. Borehole sets GP03, GP04, and GP10 are located at approximate Sta. $28+80,33+40$, and $38+20$, respectively. All the boring sets consists of three in-line borings located about $15 \mathrm{ft}$ apart. The $\mathrm{A}, \mathrm{B}$, and $\mathrm{C}$ suffix associated with each boring set designation indicates the relative position of the borings. In all cases the suffix $A, B$, and $C$ indicates the west, center, and east borings, respectively. The boring elevations, depths, and coordinates for these three sets are presented in Table 1. These borings were designed to penetrate the downstream random fill and alluvial foundation materials.

\section{Downstream toe}

Two boring sets were installed on the downstream toe service road at approximate Sta. 33+10 (GP05) and 37+70 (GP09) as shown in Figure 2. Both boring sets consist of three in-line borings spaced approximately $15 \mathrm{ft}$ apart. In all cases the $\mathrm{A}, \mathrm{B}$, and $\mathrm{C}$ suffix, associated with the boring set designation, indicates the west, center, and east borings, respectively. 


\begin{tabular}{|c|c|c|c|c|}
\hline \multicolumn{5}{|c|}{$\begin{array}{l}\text { Table } 1 \\
\text { Test Boring Coordinates and Depths }\end{array}$} \\
\hline \multicolumn{5}{|c|}{ Upstream Slope Service Road Boring Data - Set GP01 - Sta. $28+80$} \\
\hline Boring & Elevation, $\mathrm{ft}$ & Depth, $\mathrm{ft}$ & Northing & Easting \\
\hline GP01A (West) & 634.7 & 90 & $265,153.2$ & $2,023,479.4$ \\
\hline GP01B (Center) & 634.4 & 130 & $265,149.3$ & $2,023,493.0$ \\
\hline GP01C (East) & 634.4 & 130 & $265,146.8$ & $2,023,506.8$ \\
\hline \multicolumn{5}{|c|}{ Upstream Slope Service Road Boring Data - Set GP06 - Sta. $31+70$} \\
\hline Boring & Elevation, $\mathbf{f t}$ & Depth, ft & Northing & Easting \\
\hline GPOGA (West) & 634.6 & 150 & $265,073.0$ & $2,023,761.6$ \\
\hline GPO6B (Center) & 634.5 & 150 & $265,068.6$ & $2,023,774.9$ \\
\hline GPO6C (East) & 635.0 & 150 & $265,063.4$ & $2,023,789.2$ \\
\hline \multicolumn{5}{|c|}{ Upstream Slope Service Road Boring Data - Set GP02 - Sta. $33+00$} \\
\hline Boring & Elevation, $\mathrm{ft}$ & Depth, ft & Northing & Easting \\
\hline GPO2A (West) & 635.4 & 40 & $265,031.8$ & $2,023,899.9$ \\
\hline GPO2B (East) & 635.2 & 135 & $265,028.2$ & $2,023,913.6$ \\
\hline \multicolumn{5}{|c|}{ Upstream Slope Service Road Boring Data - Set GP07 - Sta. $37+80$} \\
\hline Boring & Elevation, $\mathrm{ft}$ & Depth ft & Northing & Easting \\
\hline GP07A (West) & 634.8 & 155 & $264,901.9$ & $2,024,376.7$ \\
\hline GPO7B (Center) & 634.9 & 160 & $264,906.9$ & $2,024,363.0$ \\
\hline GPO7C (East) & 634.7 & 160 & $264,911.0$ & $2,024,347.8$ \\
\hline \multicolumn{5}{|c|}{ Downstream Slope Service Road Boring Data - Set GP03 - Sta. $28+80$} \\
\hline Boring & Elevation, $\mathrm{ft}$ & Depth, ft & Northing & Easting \\
\hline GPO3A (West) & 649.9 & 135 & $264,892.4$ & $2,023,411.7$ \\
\hline GPO3B (Center) & 649.8 & 135 & $264,888.4$ & $2,023,426.8$ \\
\hline GPO3C (East) & 650.0 & 135 & $264,884.5$ & $2,023,464.8$ \\
\hline \multicolumn{5}{|c|}{ Downstream Slope Service Road Boring Data - Set GP04 - Sta. $33+40$} \\
\hline Boring & Elevation, $\mathrm{ft}$ & Depth, ft & Northing & Easting \\
\hline GPO4A (West) & 650.9 & 135 & $264,774.6$ & $2,023,850.6$ \\
\hline GPO4B (Center) & 651.0 & 135 & $264,771.5$ & $2,023,865.5$ \\
\hline GPO4C (East) & 650.7 & 135 & $264,767.4$ & $2,023,879.5$ \\
\hline
\end{tabular}




\begin{tabular}{|c|c|c|c|c|}
\hline \multicolumn{5}{|c|}{$\begin{array}{l}\text { Table } 1 \\
\text { Test Boring Coordinates and Depths }\end{array}$} \\
\hline \multicolumn{5}{|c|}{ Downstream Slope Service Road Boring Data - Set GP10 - 38 + 20} \\
\hline Boring & Elevation, $\mathrm{ft}$ & Depth, $\mathrm{ft}$ & Northing & Easting \\
\hline GP10A (West) & 650.1 & 170 & $264,639.8$ & $2,024,347.4$ \\
\hline GP10B (Center) & 650.1 & 170 & $264,642.6$ & $2,024,333.9$ \\
\hline GP10C (East) & 650.0 & 170 & $264,645.9$ & $2,024,319.8$ \\
\hline \multicolumn{5}{|c|}{ Downstream Toe Service Road Boring Data - Set GP05 - 33+ 10} \\
\hline Boring & Elevation, $\mathrm{ft}$ & Depth, ft & Northing & Easting \\
\hline GP05A (West) & 547.8 & 30 & $264,470.7$ & $2,023,744.1$ \\
\hline GP05B (Center) & 547.1 & 30 & $264,464.3$ & $2,023,758.5$ \\
\hline GP05C (East) & 546.7 & 30 & $264,458.4$ & $2,023,772.0$ \\
\hline \multicolumn{5}{|c|}{ Downstream Toe Service Road Boring Data - Set GP09 - 37+70 } \\
\hline Boring & Elevation, $\mathrm{ft}$ & Depth, ft & Northing & Easting \\
\hline GP09A (West) & 559.7 & 70 & $264,378.9$ & $2,024,190.6$ \\
\hline GP09B (Center) & 560.2 & 70 & $264,376.6$ & $2,024,205.4$ \\
\hline GP09C (East) & 561.0 & 70 & $264,374.7$ & $2,024,220.1$ \\
\hline
\end{tabular}

These coordinates are based on computed station coordinates furnished by the Survey Section Geotechnical Branch, SPK, dated 22 February 1988 and 4 April 1995. 


\section{Test Principles and Procedures}

\section{Crosshole Tests}

The purpose of running crosshole tests was to determine horizontal S-wave velocities as a function of depth. An advantage of the crosshole test as opposed to the surface seismic refraction test is its ability to detect low velocity layers underlying or sandwiched between layers of higher velocity. One shortcoming of the crosshole method is that boreholes are required for testing. Thus, crosshole seismic tests are more costly than a surface seismic refraction test, however the crosshole technique is considered to be more definitive and accurate than the surface seismic refraction test for measuring $\mathrm{S}$-wave velocities. Basically, the testing consists of measuring the arrival time of a vertically polarized $\mathrm{S}$-wave that has traveled from a source in one borehole to a detector in another borehole(s) at the same elevation. This procedure is then repeated for the next test elevation. Knowing the distance between borings and the time the S-waves take to travel across this distance the velocity can be computed (distance divided by time).

\section{Test boring installation}

The borings for crosshole sets GP01, GP02, GP03, GP04, and GP05 were installed using the Odex drilling method. This drilling method was chosen because of its ability to drill through unconsolidated materials. Another reason for selecting this drilling method is that water-based drilling fluids are not required. This is an important consideration when performing crosshole tests in coarse, highly permeable material. In very coarse materials it is possible for the drilling fluid to migrate into the formation and when set-up, alter the seismic velocity of the material being tested.

The Odex drilling method uses an eccentric (off-centered) bit unit which is attached to a down-the-hole air hammer. In this arrangement the drill bit cuts a borehole slightly larger than that of the casing. As the drill bit is advanced it pulls down, along with it, steel casing. When the bottom of the boring is reached, the rotation of the drill string is reversed causing the eccentric bit to center itself in the casing and allowing it to be withdrawn from the borehole. 
After pulling out the air hammer a 4-in. inside diameter (ID) Schedule 40 polyvinyl chloride (PVC) casing with the bottom capped was placed inside the steel casing. The annular space between the steel and PVC casing was then grouted with a material that approximated the density of the surrounding in situ material. In this case, a mixture of $10 \mathrm{lbs}$. bentonite and $10 \mathrm{lbs}$. portland cement to approximately 7.5 gal. of water was used. Grouting was carried out in one continuous operation by pumping grout through a tremie pipe and filling the annular space between the steel and PVC casings, from the bottom of the borehole to the surface. Once the boring was grouted the steel casing was pulled out.

The borings for crosshole sets GP06 and GP07 were drilled using a drillthrough casing driver system. This method was used because the Odex system had difficulty with the hydrostatic head induced by the reservoir pool at depth. Like the Odex system, this process does not require drilling fluids.

The casing driver system utilizes a preassembled drill pipe and casing. The casing is fitted with a drive shoe at the bottom and is driven into the ground by an air powered piston hammer. A drill bit is attached to the drill pipe which operates inside the casing and is driven by a rotary, top-head drive. The casing and drill pipe can be advanced independently so the drill bit can operate up inside the casing or out ahead of the casing, depending on the nature of the deposit.

Cuttings are returned to the surface by air pressure with the occasional addition of small amounts of water. The method works well in deposits with a wide range of particle size.

A Becker hammer system was used to advance the borings for crosshole sets GP09 and GP10. The Becker hammer system was used to install the crosshole borings mainly to meet project time limitations. Down-time was minimized by using the Becker hammer system since the Becker hammer was already on-site performing Becker penetration tests.

The typical Becker hammer system uses a 6-5/8 in. outside diameter (OD), double-wall casing driven into the ground by a ICE 180 , double acting diesel pile hammer. With an open bit the system can be used to retrieve a highly-disturbed sample by reverse circulation air traveling down the annulus of the two casings and returning up the center 4 -in. ID casing. With a closed end bit, the system can be used for penetration testing to supplement Standard Penetration Tests. In this case, a third casing measuring 9 in. OD was added to the system. A larger drive spout was added to the diesel hammer to drive all three casings together. The inner two casings, with an open bit, broke up the soil and/or rock and removed it up the center. The clearance between the 6-5/8 in. and the 9 in. casings is small enough that material does not enter this annulus during driving. Upon reaching the target depth, the internal 6-5/8 in. double wall can be pulled leaving the 9 in. casing in place. The PVC casing is then installed and grouted in place concurrent with the withdrawal of the 9 in. casing. 


\section{Borehole deviation surveys}

Borehole deviation (drift) surveys were conducted to determine the precise vertical alignment of each boring. Figure 5 shows the deviation probe and instrumentation used to conduct the borehole deviation surveys. The incremental borehole deviation for each elevation along with the total deviation for the boring are indicated on the control panel. Accurate reduction of data from the crosshole tests requires knowledge of the drift of each boring so that a straightline distance between borings at each test depth can be established.

\section{Crosshole testing}

S-wave velocity measurements were obtained by placing an S-wave source in the center hole (source hole) of each crosshole set and detectors, at the same elevation, in the two outer boreholes (receiver holes). For the 2-boring crosshole set located on the eastern end of the upstream service road GP02A and GP02B were the receiver and source borings, respectively. The detectors consisted of a triaxial array of geophones, or velocity transducers, (two mounted horizontally at $90 \mathrm{deg}$. to each other, and one vertically oriented) in one container. The container housing the geophones was clamped firmly to the casing wall by means of an expanding pneumatic piston. A downhole vibrator was used as a source of vertically polarized S-waves. The S-wave testing procedure consisted of lowering the vibrator in the borehole to a selected test elevation and clamping the vibrator firmly to the sidewalls of the casing with an expanding pneumatic piston. When the vibrator was in position, the operator tested a range of frequencies ( 50 to $250 \mathrm{~Hz}$ ) and selected one that propagated well (one with a high amplitude) through the transmitting medium. The time required for the $\mathrm{S}$-wave to travel from source to receiver hole was recorded using a portable, 24-channel seismograph with data-enhancement capability. This procedure was repeated at 5$\mathrm{ft}$ depth intervals from a depth of $5 \mathrm{ft}$ to the bottom of the borehole. Figure 6 illustrates the crosshole S-wave system used in this investigation. An analysis of the crosshole data obtained at each test elevation was made with the aid of the computer program CROSSHOLE developed at WES (Butler, Skoglund and Landers 1978). The program computes apparent and true S-wave velocities for each test elevation. The apparent velocity is computed using the straight-line distance between the source and receiver hole. In crosshole testing the first arrival is not always the time of arrival of the straight-line raypath. For example, when the source and receiver are located within a layer of lower velocity than either the layer above or below it the refracted wave may be the first arrival. In this case, if a straight-line raypath is assumed an apparent rather than a true velocity will be computed. Program CROSSHOLE was developed to check for possible refracted arrivals and compute the true velocity for each test elevation. Further information regarding geophysical testing and interpretation procedures used in this study is provided in Engineer Manual EM 110-1-1802 (Department of the Army 1994).

One objective of this investigation was to assess the effect of the Becker hammer-generated vibrations on the density of the dam and foundation materials and thus on the S-wave velocities. Becker hammer soundings were conducted 
between pairs of borings at several of the borehole sets. Crosshole S-wave velocity surveys were performed prior to and after Becker hammer drilling. After an initial crosshole survey, Becker hammer soundings were conducted at the following locations; a. between borings GP01A and GP01B (upstream service road), $\mathrm{b}$. between borings GP03A and GP03B (downstream service road), c. between borings GP04A and GP04B and also between GP04B and GP04C (downstream service road) and d. between borings GP05B and GP05C (downstream toe service road).

\section{Downhole Geophysical Logging}

Electromagnetic (EM) and natural gamma ray logs were conducted in each of the borings in sets GP01, GP02, GP03, GP04, and GP05. The logs were collected to aid in correlating the locations of the contacts between the shell and Recent alluvium and between the Recent and older alluvium. A brief description of the EM and gamma ray equipment, principles, and logging techniques are discussed below.

\section{Electromagnetic logs}

The EM technique is used to measure differences in soil conductivity. As in electrical resistivity, conductivity is affected by differences in soil porosity, water content, chemical nature of the groundwater and soil, and the physical nature of the soil. For a homogeneous earth, the true conductivity is the reciprocal of the true resistivity. An advantage of EM logging over conventional resistivity logging is that measurements can be collected in PVC, polytetrafluoroethylene (Teflon'), fiberglass or other non-metallic cased borings. EM logging can provide an efficient method for high-resolution, vertical delineation of soil and rock layers.

A Geonics EM39 logger was used to collect the EM logs. The EM39 logger uses a 1.5-in. dia. downhole tool to measure the electrical conductivity of the surrounding soil or rock. The downhole probe contains a transmitter and receiver coil spaced a set distance apart. The transmitter coil emits a continuous $39.2 \mathrm{kHz}$ electromagnetic signal which produces a primary field in the formation surrounding the borehole. The primary field, in turn, produces a secondary field that is sensed by the receiver coil. The strength of the secondary field is a function of the formation conductivity.

The EM logging probe includes an additional receiver coil to cancel the primary field, reduce sensitivity to the borehole fluid, and focus the horizontal response. The peak response of the instrument occurs at a radial distance of about $1 \mathrm{ft}$ from the probe and half the response is from a distance greater than $2 \mathrm{ft}$. In a well with a diameter of approximately 6 in or less, the effect of the borehole fluid on the instrument response is negligible (McNeill 1986; Taylor et al. 1989). In the SI system the units of conductivity are milliSiemens per meter $(\mathrm{mS} / \mathrm{m})$.

The inphase component, which is used primarily for calibration purposes, was also measured. The inphase component may be used to correlate geologic units between borings. When measuring the inphase component, the true zero level is 
not known since the reference level is arbitrarily set by the operator. Therefore, measurements collected in this mode are relative to a reference level and have units of parts per thousand (ppt).

As in other logging probes, the EM probe averages its response over a vertical interval. Taylor et al. (1989) show that if a zone is less than $13 \mathrm{ft}$ thick, the measured EM conductivity departs from the actual values, and the EM conductivity of zones less than $3 \mathrm{ft}$ thick is not well defined. Although the instrument does not provide good approximation of EM conductivity for zones less than $3 \mathrm{ft}$ thick, it is still useful in detecting the presence of such zones if the EM conductivity contrast between adjacent zones is sufficiently large.

\section{Gamma logs}

Gamma logs were collected using the same EM39 control unit and winch used for the downhole EM survey however, a gamma probe was used. Gamma logs can be recorded in either metallic or non-metallic cased holes. Gamma logs provide a record of the natural gamma radiation of the material surrounding a boring. The natural gamma radiation is detected by means of a scintillation crystal contained within the probe and which when impinged upon by the gamma radiation produces a flash of light. The scintillations or flashes of light are amplified in a photomultiplier tube to which the crystal is optically coupled, and the output is a pulse with amplitude proportional to that of the impinging radiation.

The most significant naturally occurring, gamma-emitting radioisotopes are potassium -40 and daughter products of the uranium and thorium- decay series. Potassium is abundant in some feldspar and mica that decompose to clay. Uranium and thorium are concentrated in clay by the processes of adsorption and ion exchange. For these reasons, fine-grained detrital sediments that contain abundant clay tend to be more radioactive than quartz sand and carbonate rocks, although numerous exceptions occur (Keys 1989). In general, shales and clays show high gamma radiation counts because radioactive elements tend to concentrate in these fine-grained materials. In igneous rocks, gamma intensity is greater in the silicic rocks, such as granite, than in basic rocks, such as andesite. Orthoclase and biotite are two minerals that contain radioisotopes in igneous rocks; they can contribute to the radioactivity of sedimentary rocks if chemical decomposition has not been too great.

The volume of material investigated by a gamma probe is related to the energy of the radiation measured, the density of the material through which the radiation must pass, and the design of the probe. Dense rock, steel casing, and cement will decrease the radiation that reaches the detector, particularly from a greater distance from the borehole. Under most conditions, 90 percent of the gamma radiation detected probably originates from material within 6 to 12 in. of the borehole wall. The volume of material contributing to the measured signal may be considered approximately spherical, with no distinct boundary at the outer surface. The vertical dimension of this volume also will depend on the length of the crystal, which will affect the resolution of thin beds. Because the detector is 
at the center of the volume being investigated, radioactivity measured when the detector is located at bed contact will be an average of the two beds.

\section{Geophysical logging procedures}

The downhole logging was conducted by lowering the EM probe at a rate of 5$10 \mathrm{ft} / \mathrm{min}$ and taking readings at $0.66-\mathrm{ft}$ intervals. When the probe reached the bottom of the boring the logging instrument was reset and readings were taken as the probe came up the boring using the same rate and distance interval. When the probe reached the surface the EM probe was substituted with the gamma probe and the hole was logged using the same procedures as used for the EM logging. The uphole and downhole data were used for comparison purposes. All readings were recorded on a digital data logger and transferred to a laptop computer at the conclusion of the survey day for subsequent processing.

\section{Surface Seismic Refraction}

The seismic refraction method utilizes the fact that the seismic velocity of a material is dependent on its elastic properties. The method is based on the assumption that materials are locally homogeneous and isotropic and that the seismic wave velocity of the subsurface materials increase with depth. In the seismic refraction method, a seismic disturbance is usually produced by means of buried explosives or by striking a metal plate or wooden plank on the ground with a sledgehammer. The location of the seismic disturbance is considered to be a point source and the disturbance is transmitted through the ground as a series of waves. Under certain conditions, when a seismic wave strikes a boundary (between two media of contrasting seismic velocities) part of the seismic energy is refracted along the boundary surface of the two media. As this energy travels along the boundary surface other seismic waves are continuously produced which travel towards the ground surface where they are detected by geophones. Geophones (velocity transducers) are implanted into the ground surface and usually laid along a straight line at regularly spaced intervals. The length of the survey line, determined by the number of and separation distance between geophones, depends on the required depth of investigation; a common rule of thumb is that the length of the line should be from three to four times the depth of interest. When a seismic disturbance sweeps past a geophone an electrical signal is generated. These signals are then transmitted, via a cable, to a seismograph where they are amplified and the time of arrival of the seismic wave at each location determined. The raw data obtained from the seismic survey consists of time of arrival at each geophone location and corresponding geophone distances. An analysis of the time-distance information allows determinations of depths to interfaces and seismic velocities to be made. In general computed depths to interfaces are within 10 percent of the true depth. General information regarding seismic refraction field survey and interpretation techniques can be found in Burger (1992), Redpath (1973), and Department of the Army (1994).

Figure 2 shows the layout and location of refraction Lines 1 through 5 . Lines 1,2 , and 3 were run in a nature trail area approximately $250 \mathrm{ft}$ west and $100 \mathrm{ft}$ south of boring set GP05. Lines 4 and 5 were run in an area near the outlet 
works approximately $500 \mathrm{ft}$ west and $200 \mathrm{ft}$ south of boring set GP05. Shear wave refraction tests were conducted for each survey line whereas, P-wave seismic tests were conducted only for survey Lines 1 and 4 . All of the refraction lines consisted of 24 geophones spaced $10 \mathrm{ft}$ apart. Forward and reverse traverses were run for each survey line in order to calculate true seismic velocities. Shotpoints were offset $10 \mathrm{ft}$ from each end of each line. A sledgehammer striking a steel plate seated on the ground surface was used as a seismic source for the Pwave lines.

The seismic source for the S-wave tests consisted of a 6 in. by 6 in. by $5 \mathrm{ft}$ wooden timber. The timber was placed on the ground surface, $10 \mathrm{ft}$ from the end of the survey line, with its long dimension oriented perpendicular to the axis of the seismic line. The test is conducted by impacting the end of the timber with a sledgehammer, initiating a horizontally polarized S-wave. The S-wave disturbance thus produced is detected by each geophone and recorded by the seismograph. The timber is then struck on the opposite end, thus reversing the polarity of the S-wave. By striking the timber on opposite ends and reversing the polarity of the S-waves, the S-wave arrival time can be determined by identifying where the two successive first arrivals separate or change polarity on the record.

In certain cases a velocity layer may not be detectable with the seismic refraction method because there is an insufficient velocity contrast or insufficient thickness of an intermediate layer. This is referred to as the "hidden layer" problem. If there is an absence of knowledge of an intermediate layer, the layer may not be detected and the interpretation of the data will underestimate the depth to the underlying layer. The presence of an intermediate layer should be suspected when there is a high velocity contrast between two successive layers. More information regarding the hidden layer problem is discussed by Won and Bevis, 1984.

\section{Chronology of Geophysical Investigations}

The geophysical investigation was conducted during four separate occasions over a one year time period. Initial plans consisted of conducting crosshole Swave tests prior to and after Becker hammer drilling tests along with downhole geophysical logging at boring sets GP01, GP02, GP03, GP04, and GP05.

Preliminary S-wave crosshole results prompted SPK personnel to install borings GP06, GP07, GP09, and GP10 for additional S-wave testing. Table 2 presents a chronology of events related to the WES geophysical investigation at Success Dam. 


\begin{tabular}{|c|c|c|c|}
\hline \multicolumn{4}{|c|}{$\begin{array}{l}\text { Table } 2 \\
\text { Chronology of Geophysical Investigation }\end{array}$} \\
\hline Boring Set & Test Conducted & Date of Testing & $\begin{array}{l}\text { Pool Elevation, } \\
\text { ft }\end{array}$ \\
\hline GP01 & Pre-Becker S-wave crosshole testing & $30 \mathrm{Apr}-1$ May 1994 & 623.5 \\
\hline GP03 & Pre-Becker S-wave crosshole testing & 1 May 1994 & 623.6 \\
\hline GP04 & Pre-Becker S-wave crosshole testing & 2-3 May 1994 & 624.0 \\
\hline GP05 & Pre-Becker S-wave crosshole testing & 3 May 1994 & 624.1 \\
\hline GP05 & Downhole geophysical logging & 4 May 1994 & 624.4 \\
\hline GPO3 & Post Becker S-wave crosshole testing & 17 May 1994 & 627.8 \\
\hline GP04 & Post Becker S-wave crosshole testing & 18 May 1994 & 627.9 \\
\hline GP01 & Post Becker S-wave crosshole testing & 19-20 May 1994 & 628.2 \\
\hline GP05 & Post Becker S-wave crosshole testing & 20 May 1994 & 628.2 \\
\hline GPO2 & Post-Becker S-wave crosshole testing & 21 May 1994 & 628.4 \\
\hline GP01 & Downhole geophysical logging & 22-23 May 1994 & 628.5 \\
\hline GPO2 & Downhole geophysical logging & 22-23 May 1994 & 628.5 \\
\hline GP03 & Downhole geophysical logging & 23 May 1994 & 628.6 \\
\hline GP04 & Downhole geophysical logging & 23 May 1994 & 628.6 \\
\hline GP06 & S-wave crosshole testing & 7 to 8 February 1995 & 596.1 \\
\hline GP07 & S-wave crosshole testing & 8 to 9 February 1995 & 596.4 \\
\hline N/A & Seismic refraction testing & 11-12 February 1995 & 597.0 \\
\hline GPO9 & S-wave crosshole testing & 9 May 1995 & $643.3^{\circ}$ \\
\hline GP10 & S-wave crosshole testing & 10 May 1995 & $643.3^{\circ}$ \\
\hline
\end{tabular}

- Pool elevation based on average for period 9-10 May $1995=643.3 \mathrm{ft}$ 


\section{Test Results}

\section{Crosshole Tests}

The crosshole S-wave results (Figures 7 through 30 ) are presented in two fashions; plots of apparent velocity versus depth and plots of true velocity versus depth. The CROSSHOLE computed true velocities results in a plot with discreet velocity layers. An average velocity profile was fit to the true velocity data. No preand post-Becker hammer tests were conducted near borehole sets GP06, GP07, GP09, or GP10. Therefore, for those crosshole sets where pre- and post-Becker hammer testing crosshole information was collected, borehole sets GP01, GP03, GP04, and GP05, only post-Becker hammer S-wave results will be presented in this section. It is noted that only post-Becker hammer crosshole S-wave data were collected for set GP02. A comparison of pre- and post-Becker S-wave test results will be discussed later in this chapter.

\section{Upstream service road}

The apparent and true crosshole S-wave velocities for boring set GP01 are presented in Figures 7 and 8, respectively. An averaged S-wave velocity profile based on the computed true velocities was determined for this crosshole set and is presented in Table 3.

\section{Table 3}

S-wave Velocity Profile for Boring Set GP01

Upstream Service Road - Sta. 28+80

\begin{tabular}{||l|l|}
\hline $\begin{array}{l}\text { Approximate Elevation } \\
\mathrm{ft}\end{array}$ & $\begin{array}{l}\text { Approximate S-wave velocity } \\
\mathrm{ft} / \mathrm{sec}\end{array}$ \\
\hline \hline $629-624$ & 500 \\
\hline $624-609$ & 775 \\
\hline $609-539$ & 625 \\
\hline $539-524$ & 1050 \\
\hline 524509 & 825 \\
\hline $509-504$ & 650 \\
\hline
\end{tabular}


The apparent and true crosshole S-wave velocities for boring set GP06 are presented in Figures 9 and 10, respectively. An averaged S-wave velocity profile based on the computed true velocities was determined for this crosshole set and is presented in Table 4.

\begin{tabular}{|c|c|}
\hline \multicolumn{2}{|c|}{$\begin{array}{l}\text { Table } 4 \\
\text { S-wave Velocity Profile for Boring Set GP06 } \\
\text { Upstream Service Road - Sta. } 31+70 \\
\end{array}$} \\
\hline $\begin{array}{l}\text { Approximate Elevation } \\
\mathrm{ft}\end{array}$ & $\begin{array}{l}\text { Approximate S-wave velocity } \\
\mathrm{ft} / \mathrm{sec}\end{array}$ \\
\hline $630-620$ & 825 \\
\hline $620-600$ & 900 \\
\hline $600-580$ & 675 \\
\hline 580-535 & 900 \\
\hline $535-520$ & 2250 \\
\hline $520-485$ & 1650 \\
\hline
\end{tabular}

The apparent and true crosshole S-wave velocities for boring set GP02 are presented in Figures 11 and 12, respectively. An averaged S-wave velocity profile based on the computed true velocities was determined for this crosshole set and is presented in Table 5. It is again noted that this crosshole set consisted of two borings and that no pre-Becker hammer measurements were collected.

\section{Table 5}

S-wave Velocity Profile for Boring Set GP02

Upstream Service Road - Sta. 33+00

\begin{tabular}{||l|l|}
\hline $\begin{array}{l}\text { Approximate Elevation } \\
\mathrm{ft}\end{array}$ & $\begin{array}{l}\text { Approximate S-wave velocity } \\
\mathrm{ft} / \mathrm{sec}\end{array}$ \\
\hline \hline $630-595$ & 600 \\
\hline
\end{tabular}

The apparent and true crosshole S-wave velocities for boring set GP07 are presented in Figures 13 and 14, respectively. An averaged S-wave velocity profile based on the computed true velocities was determined for this crosshole set and is presented in Table 6.

Plots of the apparent and averaged true crosshole S-wave velocities for the borings located along the upstream service road are shown in Figures 15 and 16, respectively. 


\begin{tabular}{|c|c|}
\hline \multicolumn{2}{|c|}{$\begin{array}{l}\text { Table } 6 \\
\text { S-wave Velocity Profile for Boring Set GP07 } \\
\text { Upstream Service Road - Sta. } 37+80\end{array}$} \\
\hline $\begin{array}{l}\text { Approximate Elevation } \\
\text { ft }\end{array}$ & $\begin{array}{l}\text { Approximate S-wave velocity } \\
\mathrm{ft} / \mathrm{sec}\end{array}$ \\
\hline $630-590$ & 900 \\
\hline $590-555$ & 1100 \\
\hline $555-540$ & 525 \\
\hline $540-530$ & 1500 \\
\hline $530-475$ & 1900 \\
\hline
\end{tabular}

\section{Downstream service road}

The apparent and true crosshole S-wave velocities for boring set GP03 are presented in Figures 17 and 18, respectively. An averaged S-wave velocity profile based on the computed true velocities was determined for this crosshole set and is presented in Table 7.

\begin{tabular}{||l|l|}
\hline \hline $\begin{array}{l}\text { Table } 7 \\
\text { S-wave Velocity Profile for Boring Set GP03 } \\
\text { Downstream Service Road - Sta. }\end{array}$ \\
\hline \hline $\begin{array}{l}\text { Approximate Elevation } \\
\text { ft }\end{array}$ & $\begin{array}{l}\text { Approximate S-wave velocity } \\
\text { ft/sec }\end{array}$ \\
\hline \hline $645-630$ & 700 \\
\hline $630-610$ & 900 \\
\hline $610-570$ & 950 \\
\hline $570-555$ & 1025 \\
\hline $555-540$ & 1200 \\
\hline $540-520$ & 2125 \\
\hline
\end{tabular}

The apparent and true crosshole S-wave velocities for boring set GP04 are presented in Figures 19 and 20, respectively. An averaged S-wave velocity profile based on the computed true velocities was determined for this crosshole set and is presented in Table 8.

The apparent and true crosshole S-wave velocities for boring set GP10 are presented in Figures 21 and 22, respectively. An averaged S-wave velocity profile based on the computed true velocities was determined for this crosshole set and is presented in Table 9. 


\begin{tabular}{||l|l||}
\hline \hline \multicolumn{2}{||l||}{$\begin{array}{l}\text { Table } 8 \\
\text { S-wave Velocity Profile for Boring Set GPO4 } \\
\text { Downstream Service Road - Sta. } 33+40\end{array}$} \\
\hline \hline $\begin{array}{l}\text { Approximate Elevation } \\
\mathrm{ft}\end{array}$ & $\begin{array}{l}\text { Approximate S-wave velocity } \\
\text { ft/sec }\end{array}$ \\
\hline \hline $646-631$ & 750 \\
\hline $631-606$ & 875 \\
\hline $606-596$ & 925 \\
\hline $596-586$ & 1000 \\
\hline $586-576$ & 1100 \\
\hline $576-561$ & 1275 \\
\hline $561-541$ & 1425 \\
\hline $541-516$ & 1800 \\
\hline
\end{tabular}

\begin{tabular}{|c|c|}
\hline \multicolumn{2}{|c|}{$\begin{array}{l}\text { Table } 9 \\
\text { S-wave Velocity Profile for Boring Set GP } 10 \\
\text { Downstream Service Road - Sta. } 38+20\end{array}$} \\
\hline $\begin{array}{l}\text { Approximate Elevation } \\
\mathrm{ft}\end{array}$ & $\begin{array}{l}\text { Approximate S-wave velocity } \\
\mathrm{ft} / \mathrm{sec}\end{array}$ \\
\hline $645-630$ & 800 \\
\hline $630-605$ & 1000 \\
\hline $605-590$ & 1150 \\
\hline $590-560$ & 1300 \\
\hline $560-545$ & 1000 \\
\hline $545-535$ & 1300 \\
\hline $535-480$ & 2200 \\
\hline
\end{tabular}

Plots of the apparent and averaged true crosshole S-wave velocities for the downstream service road are shown in Figures 23 and 24, respectively.

\section{Downstream toe}

The apparent and average true crosshole S-wave velocities for boring set GP05 located on the downstream toe of the dam are presented in Figures 25 and 26, respectively. An averaged S-wave velocity profile based on the computed true velocities was determined for this crosshole set and is presented in Table 10.

The apparent and average true crosshole S-wave velocities for boring set GP09 located on the downstream toe of the dam are presented in Figures 27 and 28, 
respectively. An averaged S-wave velocity profile based on the computed true velocities was determined for this crosshole set and is presented in Table 11.

\begin{tabular}{|c|c|}
\hline \multicolumn{2}{|c|}{$\begin{array}{l}\text { Table } 10 \\
\text { S-wave Velocity Profile GP05 } \\
\text { Downstream Toe - Sta. } 33+10\end{array}$} \\
\hline $\begin{array}{l}\text { Approximate Elevation } \\
\mathrm{ft}\end{array}$ & $\begin{array}{l}\text { Approximate S-wave velocity } \\
\mathrm{ft} / \mathrm{sec}\end{array}$ \\
\hline $542-537$ & 875 \\
\hline $537-527$ & 1325 \\
\hline $527-517$ & \\
\hline
\end{tabular}

\section{Table 11}

S-wave Velocity Profile GP09

Downstream Toe - Sta. $37+70$

\begin{tabular}{||l|l|}
\hline $\begin{array}{l}\text { Approximate Elevation } \\
\mathrm{ft}\end{array}$ & $\begin{array}{l}\text { Approximate S-wave velocity } \\
\mathrm{ft} / \mathrm{sec}\end{array}$ \\
\hline $555-540$ & 650 \\
\hline $540-490$ & 1800 \\
\hline
\end{tabular}

Plots of the apparent and average true crosshole S-wave velocities along the downstream toe are shown in Figures 29 and 30, respectively.

\section{Downhole Geophysical Logs}

The downhole conductivity, inphase, and gamma logs for each boring are presented in Figures 31 through 44. The logs of each of the three tests conducted in each boring are plotted side by side to aid in interpreting the logs. As previously mentioned, the purpose for running these logs was to assist in detecting the dam-foundation contact and changes in the alluvial material.

\section{Upstream service road}

The downhole logs for borings GP01 and GP02, located on the upstream service road are shown in Figures 31 through 35 . The logs for borehole set GP01 (Figures 31 through 33) show a poor correlation between boreholes above an approximate elevation of $550 \mathrm{ft}$., which corresponds to the shell material. The poor correlation is most likely caused by the heterogeneous nature of the shell material. Some of the big "kicks" seen in the logs may be indicative of areas with high grout takes. The logs for set GP01 exhibit an increase in conductivity at an elevation of approximately $550 \mathrm{ft}$. This may indicate the extent of the shell materials. At an elevation of approximately $535 \mathrm{ft}$ the logs collected in borings GP01B and GP01C show a significant increase in conductivity and a decrease in 
natural gamma. Also, the inphase component of the EM becomes nearly zero. A distinct change in material type, which may be indicative of the embankmentalluvium contact, is interpreted at approximate elevation $535 \mathrm{ft}$.

Only one boring, boring GP02B, of boring set GP02 penetrated into the alluvial materials. Boring GP02A was approximately $40 \mathrm{ft}$ in depth and therefore, did not penetrate the alluvium. The logs for boring GP02B (Figure 35) show a change in the conductivity readings at an elevation of about $550 \mathrm{ft}$ indicating a material change. Between an elevation of about 535 and $540 \mathrm{ft}$ there is a significant increase in conductivity and the inphase log shows a smoother characteristic with average values near zero. The changes in the values of the logs encountered at a depth between 535 and $540 \mathrm{ft}$ are indicative of a material change and correlate very well with the elevation of the material change encountered by the geophysical logs run in boring set GP01 at elevation $535 \mathrm{ft}$.

\section{Downstream service road}

The downhole logs for boring sets GP03 and GP04, located on the downstream service road, are shown in Figures 36 through 41 . The logs for borehole sets GP03 and GP04 do not show a good correlation between boreholes above an approximate elevation of $560 \mathrm{ft}$., which corresponds to the shell material. Examination of the downstream service road geophysical logs indicate a possible change in material type at approximate elevation 560 and $540 \mathrm{ft}$. This may be associated with textural changes in the alluvial material and/or with changes in the total dissolved solids found in the groundwater.

\section{Downstream toe}

The results of the logs conducted in boring set GP05, located on the downstream toe, are shown in Figures 42 through 44 . These logs were run in alluvial material. The inphase response shows very little fluctuation. The upper $5 \mathrm{ft}$ of the EM logs should be disregarded because of interference caused by the metal tripod used to lower the sonde into the borings.

\section{Surface Seismic Refraction}

\section{S-wave refraction}

The results of $S$-wave refraction lines 1,2 , and 3 , conducted in the nature trail area, are presented in Figures 45 through 47 , respectively. The velocities and layer depths for the three lines agree very well. The refraction tests indicated three velocity zones. A summary of the $\mathrm{S}$-wave refraction results for lines 1 through 3 are presented in Table 12 .

The results of S-wave refraction lines 4 and 5 , conducted in the vicinity of the outlet works, are presented in Figures 48 and 49, respectively. The velocities and layer depths for these two lines agree very well. The refraction tests indicated three velocity zones. A summary of the S-wave refraction results for lines 4 and 5 are presented in Table 13. 


\section{Table 12}

Summary of S-wave seismic refraction results, lines 1 through 3

\begin{tabular}{||l|l|l|l||}
\hline & $\begin{array}{l}\text { Average Layer } \\
\text { Velocity, fps }\end{array}$ & $\begin{array}{l}\text { Approximate depth to } \\
\text { top of velocity layer, } \mathrm{ft}\end{array}$ & $\begin{array}{l}\text { Corresponding } \\
\text { material type }\end{array}$ \\
\hline \hline 1 & 400 & Surface & $\begin{array}{l}\text { Dry, loose, soft, } \\
\text { overburden material }\end{array}$ \\
\hline 2 & 1000 & 3 to 6 & Alluvium \\
\hline 3 & 3825 & 12 to 22 & $\begin{array}{l}\text { Alluvium-weathered } \\
\text { bedrock }\end{array}$ \\
\hline
\end{tabular}

- Corresponding material type based on seismic velocities and geologic logs

\section{Table 13}

Summary of S-wave seismic refraction results, lines 4 and 5

\begin{tabular}{||l|l|l|l||}
\hline \hline & $\begin{array}{l}\text { Average Layer } \\
\text { Velocity, fps }\end{array}$ & $\begin{array}{l}\text { Approximate depth to } \\
\text { top of velocity layer, ft }\end{array}$ & $\begin{array}{l}\text { Corresponding } \\
\text { material type }\end{array}$ \\
\hline \hline 1 & 575 & Surface & $\begin{array}{l}\text { Dry, loose, soft, } \\
\text { overburden material }\end{array}$ \\
\hline 2 & 900 & 0 to 5 & Alluvium \\
\hline 3 & 5125 & 22 to 33 & Bedrock \\
\hline
\end{tabular}

- Corresponding material type based on seismic velocities and geologic logs

\section{P-wave refraction}

The results of $\mathrm{P}$-wave refraction line 1 , which is coincident with $\mathrm{S}$-wave line 1, indicates two velocity layers as shown in Figure 50. The top layer has an approximate P-wave velocity of $800 \mathrm{fps}$ and is about $8 \mathrm{ft}$ thick, whereas the bottom layer has a velocity of 8750 fps. Comparison of S-wave line 1 and Pwave line 1 indicates a discrepancy in the number of layers and depths to the layers. It is suspected that there is at least one and possibly two intermediate layers (hidden layers) that are too thin to detect using the $\mathrm{P}$-wave refraction method. If an intermediate layer with a velocity of $1500 \mathrm{fps}$ is assumed to be present it is possible for the layer to be on the order of 6 to $7 \mathrm{ft}$ and not be detected. If the thickness of the top layer is assumed to be $5 \mathrm{ft}$ then the depth to the high velocity layer is computed to increase from $8 \mathrm{ft}$ to about $11-12 \mathrm{ft}$ which matches the depth to the high velocity layer for S-wave refraction line 1 .

The results of P-wave refraction line 4, which is coincident with S-wave line 4, indicates three velocity layers as shown in Figure 51. The top layer has an approximate P-wave velocity of $1050 \mathrm{fps}$ and is about 3-5 ft thick. The intermediate layer has a velocity of about $1500 \mathrm{fps}$ and varies in depth between 15 and $18 \mathrm{ft}$. The deepest layer detected has a velocity of approximately $10,450 \mathrm{fps}$. It is again suspected that there may be a hidden intermediate velocity layer since there is about a $10 \mathrm{ft}$ discrepancy in the depth to the top of the bottom layer 
between the $\mathrm{P}$ - and $\mathrm{S}$-wave refraction lines and because the velocity contrast between the 10,450 fps and $1500 \mathrm{fps}$ layer is so great. If a layer velocity of $4800 \mathrm{fps}$, corresponding to saturated alluvium, is assumed to overly the $10,450 \mathrm{fps}$ layer, the computed depth to the bottom layer would increase and would more nearly agree with the S-wave velocity data. Computer modeling indicates that using a model with velocities of $1050,1450,4800$, and $10,450 \mathrm{fps}$ with respective thicknesses of 5,10 , and $10 \mathrm{ft}$, the $4800 \mathrm{fps}$ layer would be on the verge of being detectable. This model, with a depth to the high velocity layer of $25 \mathrm{ft}$, corresponds very well with the S-wave refraction line.

\section{Discussion of Results}

Profiles of the averaged true crosshole S-wave velocities, showing layer thicknesses and the location of layers in the alluvial materials interpreted from the downhole geophysical logging for sections through approximate Sta. $28+80$, Sta. $33+20$, and Sta. $37+90$ are shown in Figures 52 through 54, respectively. Examination of these sections indicate that in general, the downstream random fill material S-wave velocities are greater than those for the upstream side random fill.

Information for the section drawn through Sta. $28+80$ (Figure 52) indicates that at elevation $624 \mathrm{ft}$. of the upstream random fill the average true $\mathrm{S}$-wave velocity increases from 500 to $775 \mathrm{fps}$. Between elevations of 609 and $539 \mathrm{ft}$. the upstream random fill material exhibits an average true velocity of $625 \mathrm{fps}$. The downstream shell average true crosshole data (crosshole set GP03) indicate a gradual velocity increase with depth ranging between 700 and $1200 \mathrm{fps}$ between elevations 645 and $540 \mathrm{ft}$. The average true S-wave velocities for the alluvium under the upstream shell are anomalously low with velocities ranging between 650 and $1050 \mathrm{fps}$ and decrease in velocity with depth. The alluvium beneath the downstream shell has an average true velocity of $2125 \mathrm{fps}$. Based on the results of crosshole testing, the interpreted dam-foundation contact elevations beneath the upstream and downstream shells, are 539 and $540 \mathrm{ft}$, respectively. The upstream and downstream geophysical logs indicate a material change, presumably the dam-foundation contact, at approximate elevations 534 and $540 \mathrm{ft}$, respectively.

The average results of S-wave refraction lines 4 and 5 run downstream of the dam indicate velocities ranging from 575 fps at the surface to $5125 \mathrm{fps}$ at an elevation of approximately $520 \mathrm{ft}$.

Figure 53 shows the section through approximate Sta. $33+20$. The upstream crosshole data indicate a zone extending from elevation 630 to $595 \mathrm{ft}$ with an average true S-wave velocity of $600 \mathrm{fps}$. Elevation $595 \mathrm{ft}$ was the extent of upstream crosshole testing. The average true crosshole $S$-wave velocities from boring set GP04 show a gradual velocity increase with depth for the downstream shell materials ranging between 750 and 1425 fps between elevations of 646 and $541 \mathrm{ft}$. At elevation $541 \mathrm{ft}$ the $\mathrm{S}$-wave velocity beneath the downstream shell increases to $1800 \mathrm{fps}$. The $1800 \mathrm{fps}$ velocity zone probably corresponds to alluvium. Crosshole testing at the toe of the dam indicates an average true velocity range of 875 to $1525 \mathrm{fps}$ which increase with depth. The upstream and 
downstream geophysical logs indicate a material change, presumably the damfoundation contact, at approximate elevations 540 and $535 \mathrm{ft}$, respectively.

The seismic refraction lines run near the toe of this section indicate S-wave velocities ranging between $400 \mathrm{fps}$ at the surface to $3825 \mathrm{fps}$ at an elevation of approximately $530 \mathrm{ft}$. The $3825 \mathrm{fps}$ seismic refraction velocity is significantly higher than the S-wave velocities computed from crosshole testing at the same elevation range. The $S$-wave velocities beneath the downstream shell are expected to be higher than those measured at the toe since the shear modulus increases with increasing vertical stress (Seed and Idriss 1970).

Figure 54 presents the section through approximate Sta. $37+90$. The interpreted S-wave velocity zoning for the upstream shell material indicates average true $S$-wave velocities ranging between 525 and 1500 fps between elevations 630 and $530 \mathrm{ft}$. Between elevation 555 and $540 \mathrm{ft}$ a low velocity zone with an average true velocity of $525 \mathrm{fps}$ is encountered. The downstream shell materials have average true velocities ranging between 800 and $1300 \mathrm{fps}$ between elevation 645 and $535 \mathrm{ft}$. A low velocity zone with a velocity of $1000 \mathrm{fps}$ is interpreted between elevation 560 and $545 \mathrm{ft}$ under the downstream shell. This low velocity zone occurs at approximately the same elevation as the low velocity zone found under the upstream shell. The average true S-wave velocity of the alluvial material underlying the upstream shell is $1900 \mathrm{fps}$ and is encountered at an elevation of approximately $530 \mathrm{ft}$, whereas the alluvial material underlying the upstream shell, at approximate elevation $535 \mathrm{ft}$, has a velocity of $2200 \mathrm{fps}$. The average true S-wave velocity for the alluvium at the toe of the dam (boring set GP09) ranges between 650 and 1800 fps.

Figures 55 through 57 show the average true crosshole S-wave velocity zones for the longitudinal cross sections along the upstream and downstream service roads and downstream toe, respectively. The average upstream and downstream shell velocity profiles are relatively constant along the dam with the exception occurring at Sta. $28+80$ on the upstream service road (boring set GP01). The Swave velocity profile for the shell materials in boring set GP01 are significantly lower than the profiles determined for boring sets GP06 and GP07 also located on the upstream service road.

As previously mentioned an objective of the test program was to determine the effect, if any, of Becker hammer drilling on S-wave velocities of adjacent soils. To meet this objective pre- and post-Becker hammer testing crosshole information was collected between a pair of boreholes in borehole sets GP01, GP03, GP04, and GP05. The apparent pre- and post Becker hammer testing S-wave results for borehole sets GP01, GP03, GP04, and GP05 are shown in Figures 58 through 61, respectively. A matched-pair $t$ test procedure as described in Dowdy and Weardon, 1983 was employed to determine if there is a significant difference in the $\mathrm{S}$-wave velocities prior to and after Becker hammer testing. The matched-pair $t$ test indicates that the pre- and post-Becker hammer crosshole velocity data is significantly different only between boring pair GP03B- GP03A using a 95 percent confidence interval. 


\section{Conclusions}

The following conclusions were drawn based on the results of the geophysical investigation conducted at Success Dam:

a. The average true crosshole S-wave velocities for the upstream shell range between 500 and $1500 \mathrm{fps}$. The average true crosshole $S$-wave velocities for the upstream shell materials show little increase in velocity as a function of depth. Of the three boring sets that fully penetrate the upstream shell, boring set GP01, located at Sta. $28+80$, indicates the lowest $S$-wave velocities for the upstream shell materials. A $15 \mathrm{ft}$ thick low velocity zone with an average true velocity of $525 \mathrm{fps}$ is encountered in boring set GP07, located on the upstream service road, between approximate elevations 555 and $540 \mathrm{ft}$.

b. The average true crosshole $S$-wave velocities for the alluvium beneath the upstream shell range between 650 and $2250 \mathrm{fps}$. The lowest alluvium average true velocities were detected at Sta. $28+80$ (boring set GP01), and range between 650 and $1050 \mathrm{fps}$. The dam-foundation contact beneath the upstream shell is interpreted to occur between elevations 530 and $539 \mathrm{ft}$.

c. The average true crosshole S-wave velocities for the downstream shell range between 700 and 1425 fps. Boring sets GP04 and GP10 show an Swave velocity increase as a function of depth in the shell materials. Boring set GP03 also shows an increase in velocity with depth, however the rate of the velocity increase is less than the rates for boring sets GP04 and GP10.

d. The average true crosshole $S$-wave velocities for the alluvium beneath the downstream shell range between 1800 and 2200 fps. The dam-foundation contact beneath the downstream shell is interpreted to occur between approximate elevations 535 and $541 \mathrm{ft}$.

e. The average true crosshole $S$-wave velocities for the alluvium at the downstream toe range between 650 and 1800 fps and increase with depth.

f. The seismic refraction lines run along the downstream toe of the dam indicate true velocities ranging between 400 and 575 fps from the surface to a depth of about $5 \mathrm{ft}, 900$ and $1000 \mathrm{fps}$ (alluvium) to approximate depths of 12 to 
$33 \mathrm{ft}$, and underlain by a 3825 to $5125 \mathrm{fps}$ layer which may correspond to either older alluvium and/or bedrock.

g. The downhole geophysical logs gave indications of the dam-foundation contact and agreed with the S-wave velocity zones presumed to correspond with the alluvial materials.

h. A matched-pair $t$ test indicates that the pre- and post-Becker hammer crosshole velocity data are significantly different only between boring pair GP03B-GP03A using a 95 percent confidence interval. 


\section{References}

Burger, H. R. (1992). Exploration geophysics of the shallow subsurface. Prentice Hall, New Jersey.

Butler, D. K., Skoglund, G. R., and Landers, G.B. (1978). "CROSSHOLE: An interpretive computer code for crosshole seismic test results, documentation, and examples," Miscellaneous Paper S-78-8, U.S. Army Engineer Waterways Experiment Station, Vicksburg, MS.

Department of the Army. (1994). "Geophysical exploration for engineering and environmental investigations," Engineer Manual EM1110-1-1802, Office of the Chief of Engineers, Washington, D.C.

Dowdy, S. and Weardon, S. (1983). Statistics for research. John Wiley \& Sons, New York.

Keys, W. S. (1989). Borehole geophysics applied to ground-water investigations, National Water Well Association, Dublin, OH.

McNeill, J. D. (1986). "Geonics EM39 borehole conductivity meter - theory of operation," Mississauga, Ontario, Canada.

Redpath, B. B. (1973). "Seismic refraction exploration for engineering site investigations," Technical Report E-73-4, U.S. Army Engineer Waterways Experiment Station, Vicksburg, MS.

Seed, H. B. and Idriss, I. M. (1970). "Soil moduli and damping factors for dynamic response analysis," Report No. EERC 70-10, University of California, Berkeley.

Taylor, K. C., Hess, J. W., and Mazella, A. (1989). "Field evaluation of a slim-hole borehole induction tool," Ground Water Monitoring and Remediation, 9(1), 100-104.

Won I. J. and Bevis, M. (1984). "The hidden-layer problem revisited," Geophysics, 49(11), 2052-2056. 


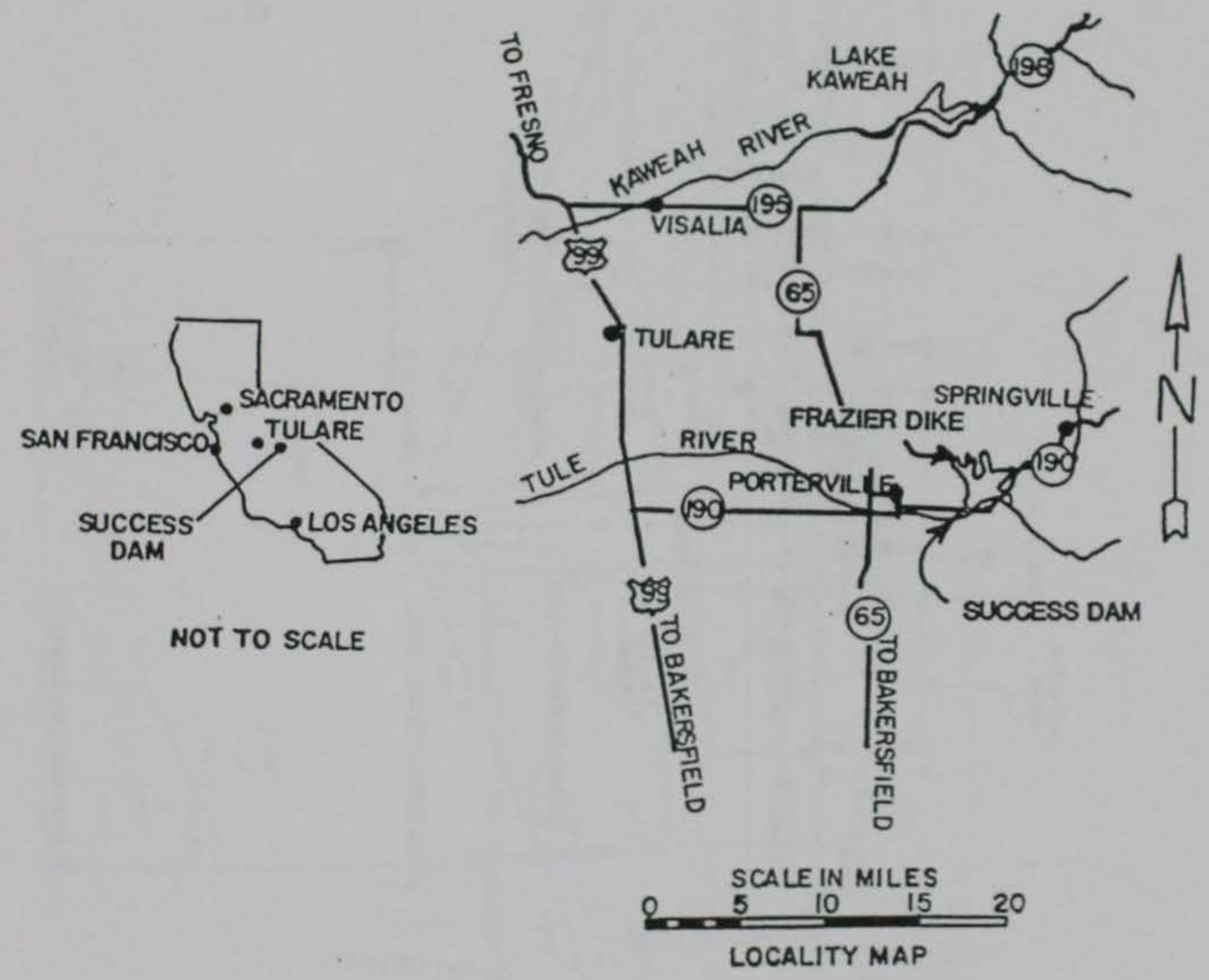

Figure 1. Locality map 


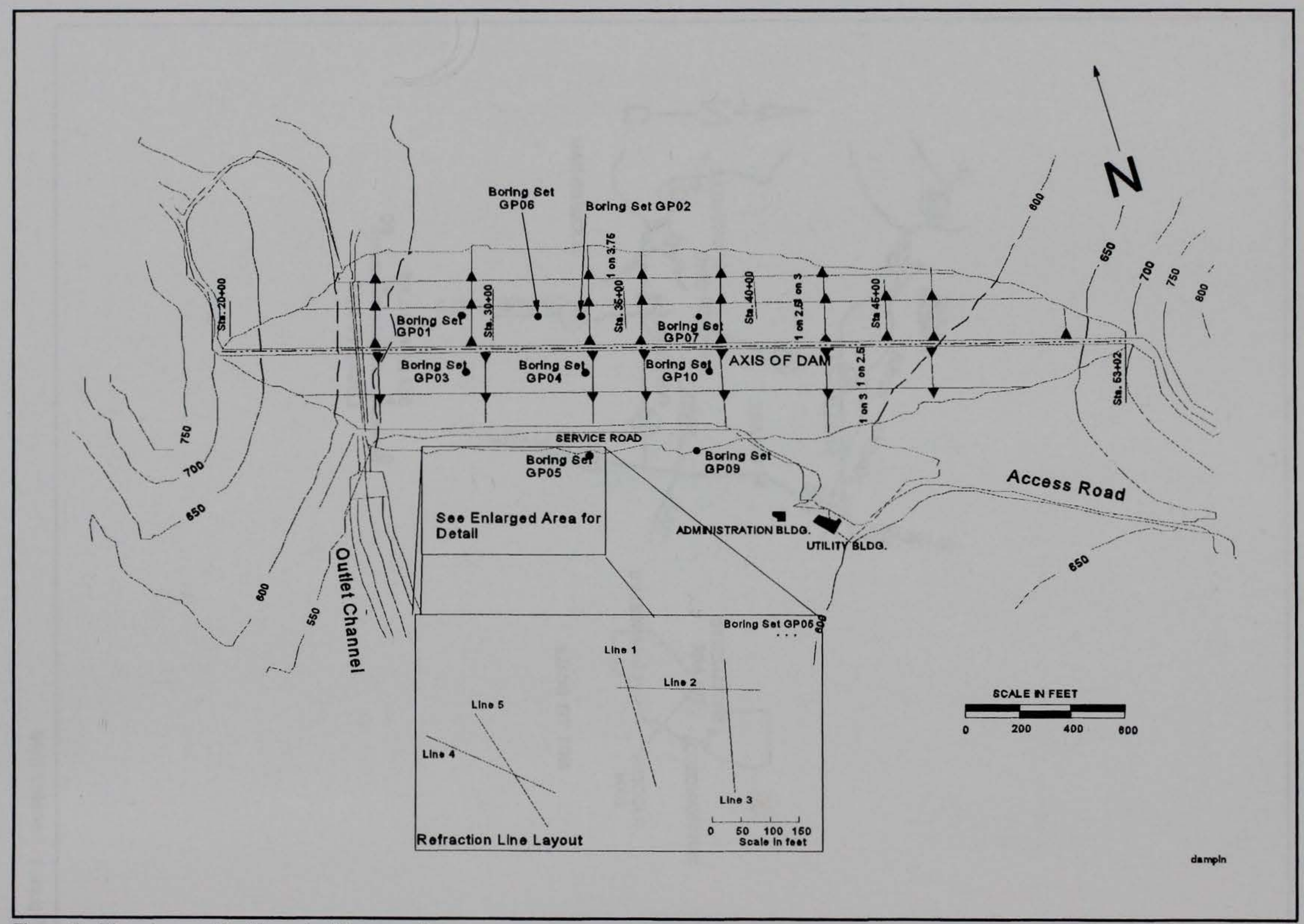

Figure 2. Plan view and test layout of Success Dam 


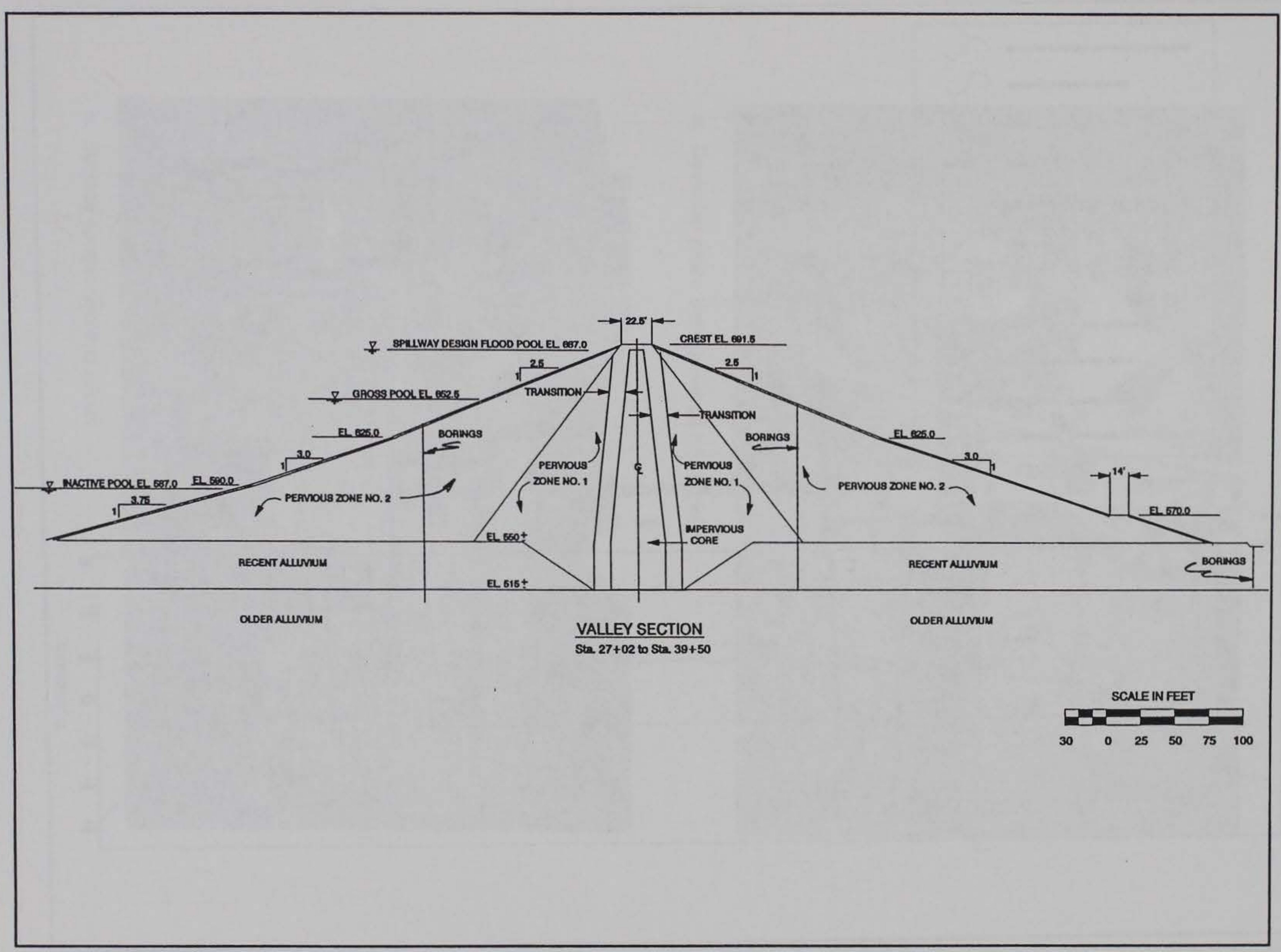

Figure 3. Transverse cross section of Success Dam 


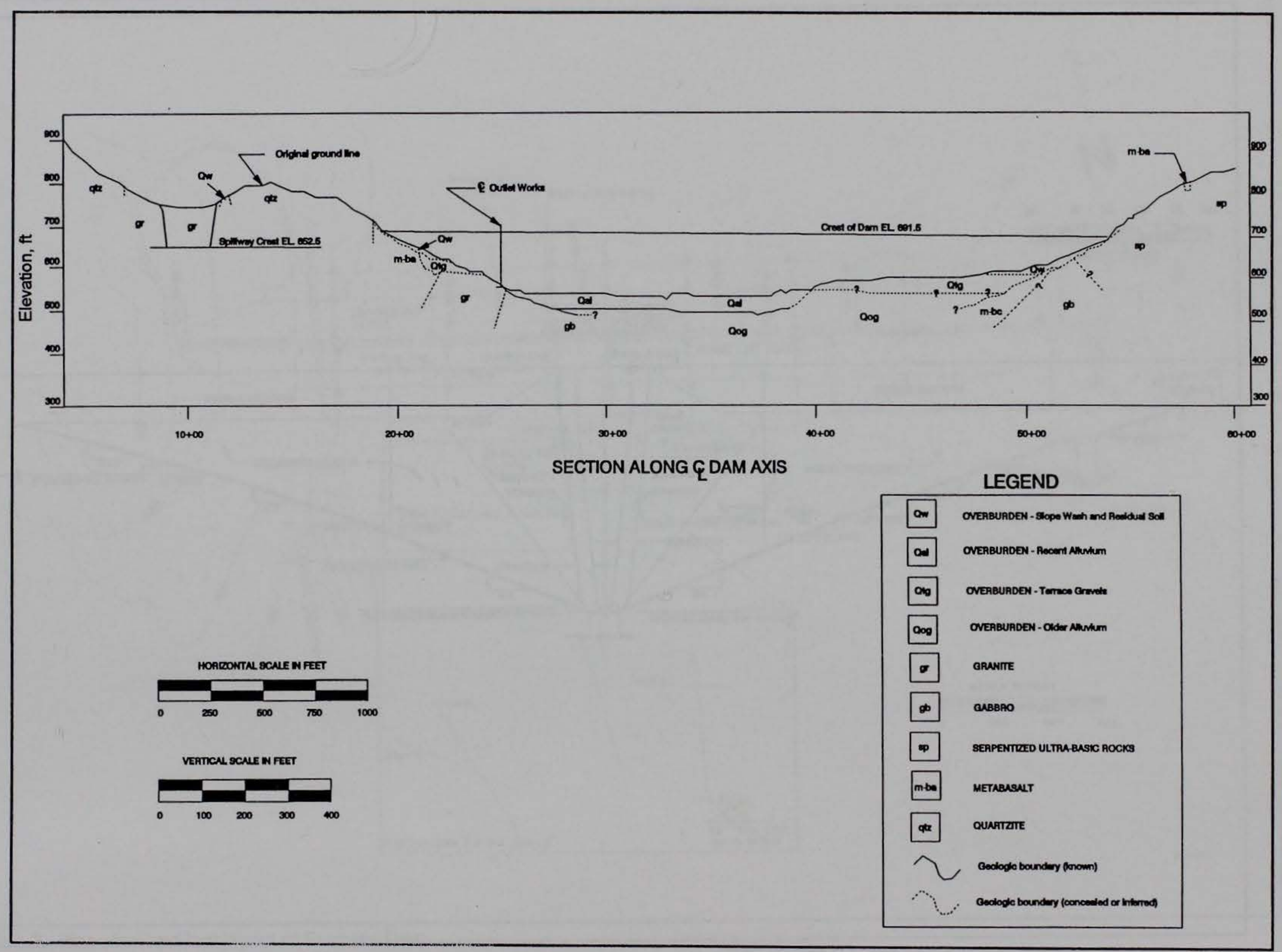

Figure 4. Longitudinal cross section of Success Dam 


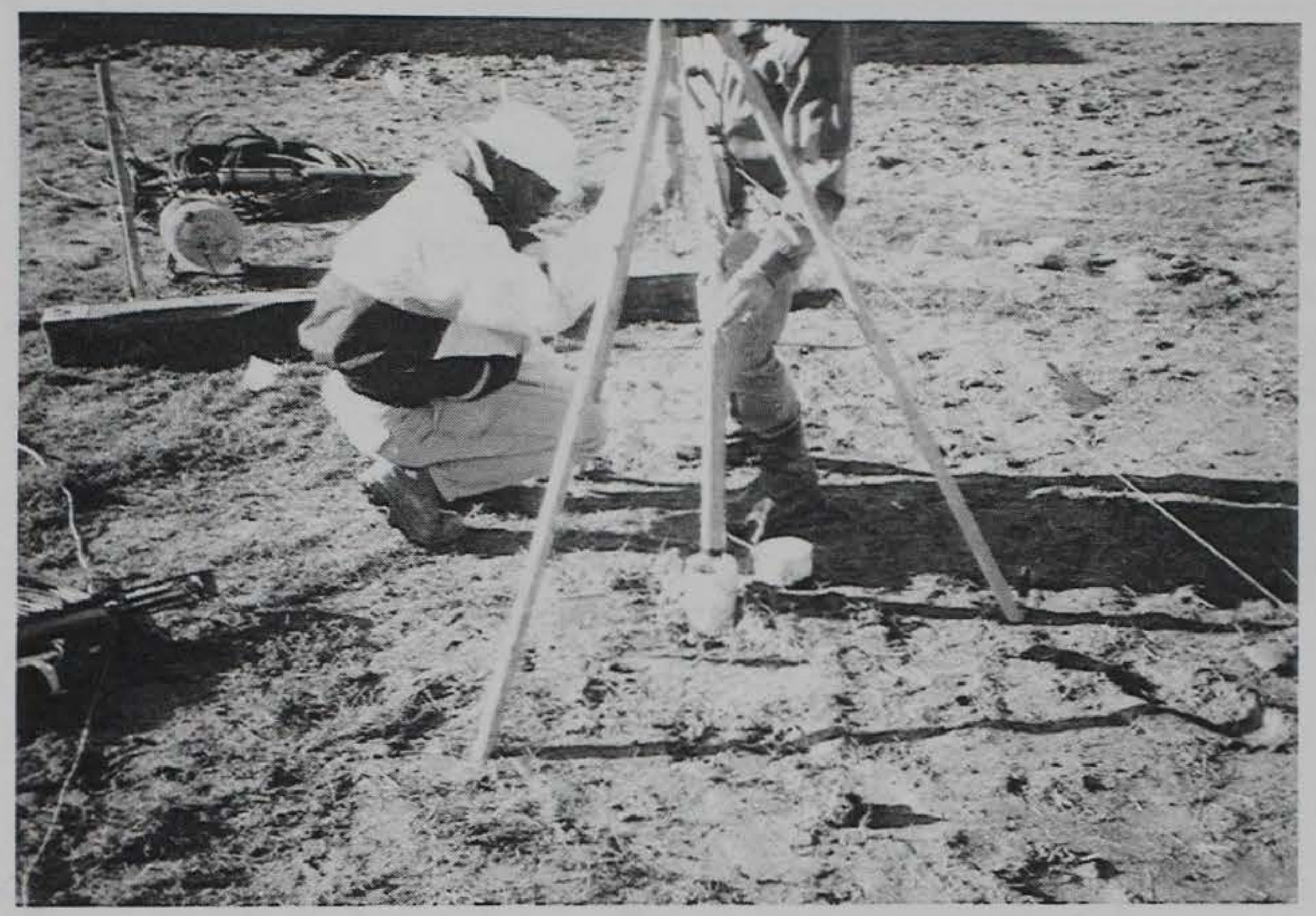

a. Deviation probe being lowered into boring

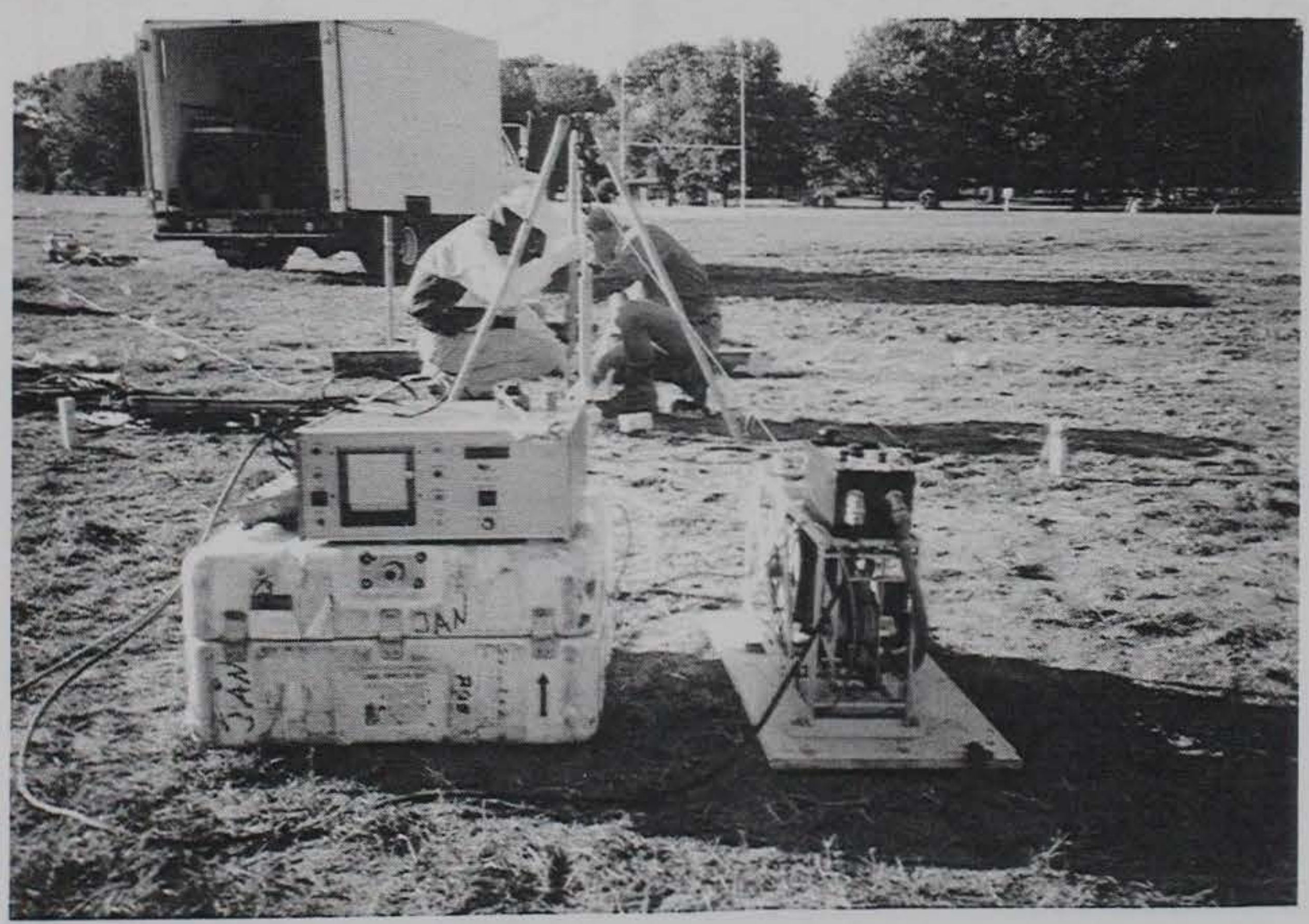

b. Surface control unit and winch

Figure 5. Borehole deviation tool 


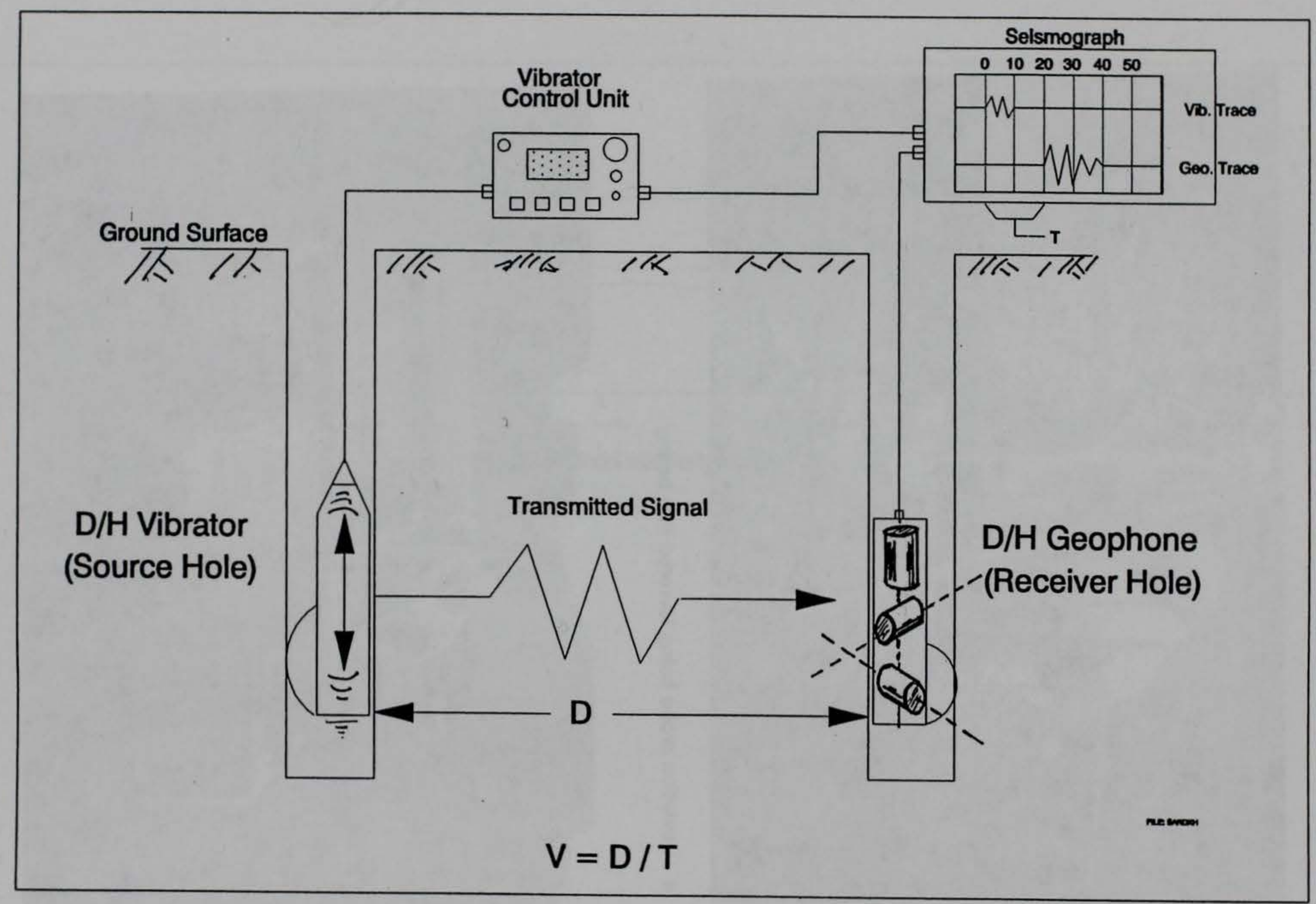

Figure 6. Crosshole S-wave testing setup 


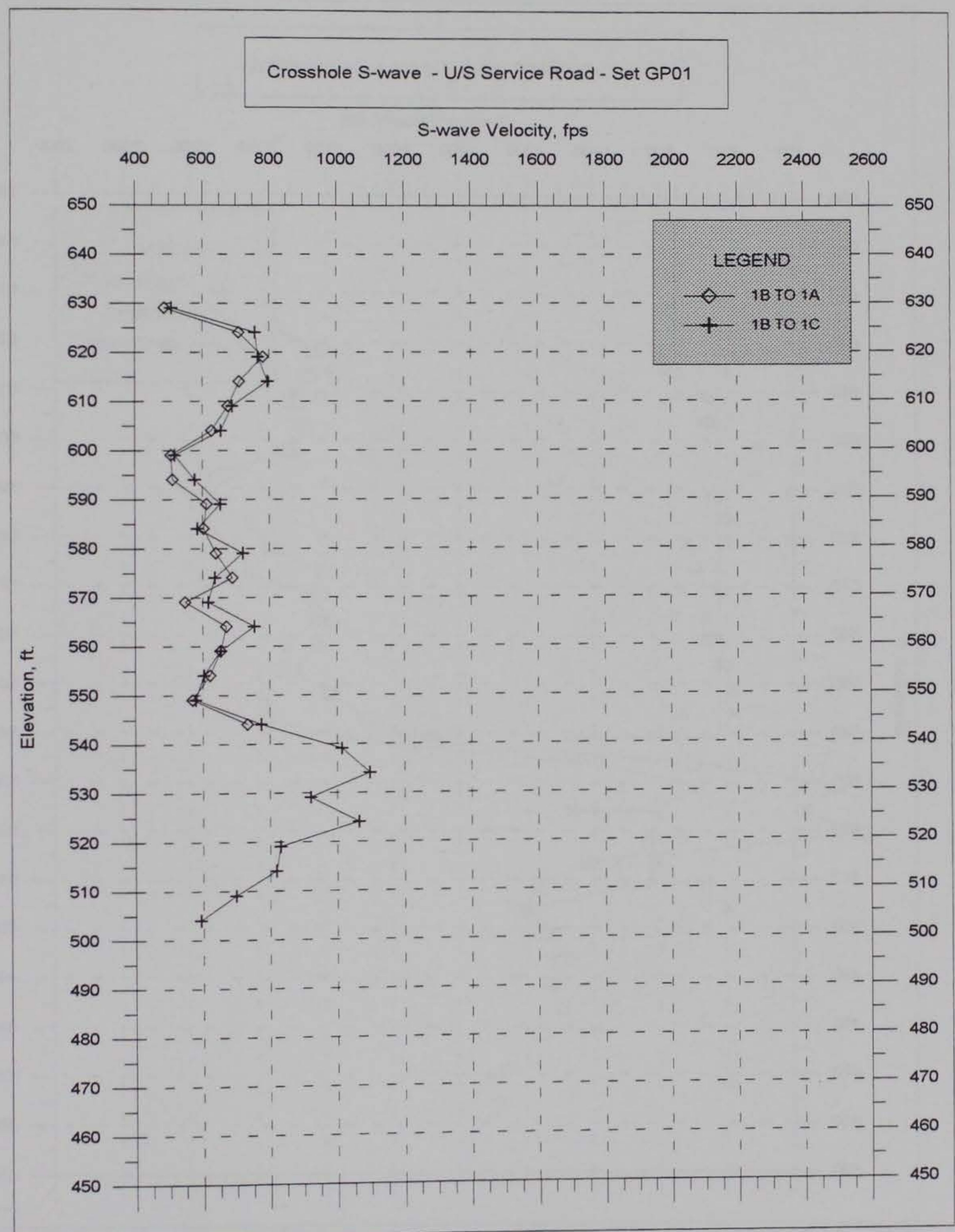

Figure 7. Apparent crosshole S-wave velocities, boring set GP01, upstream service road, Sta. $28+80$ 
Crosshole S-wave - U/S Bench - Set GP01

S-wave Velocity, fps

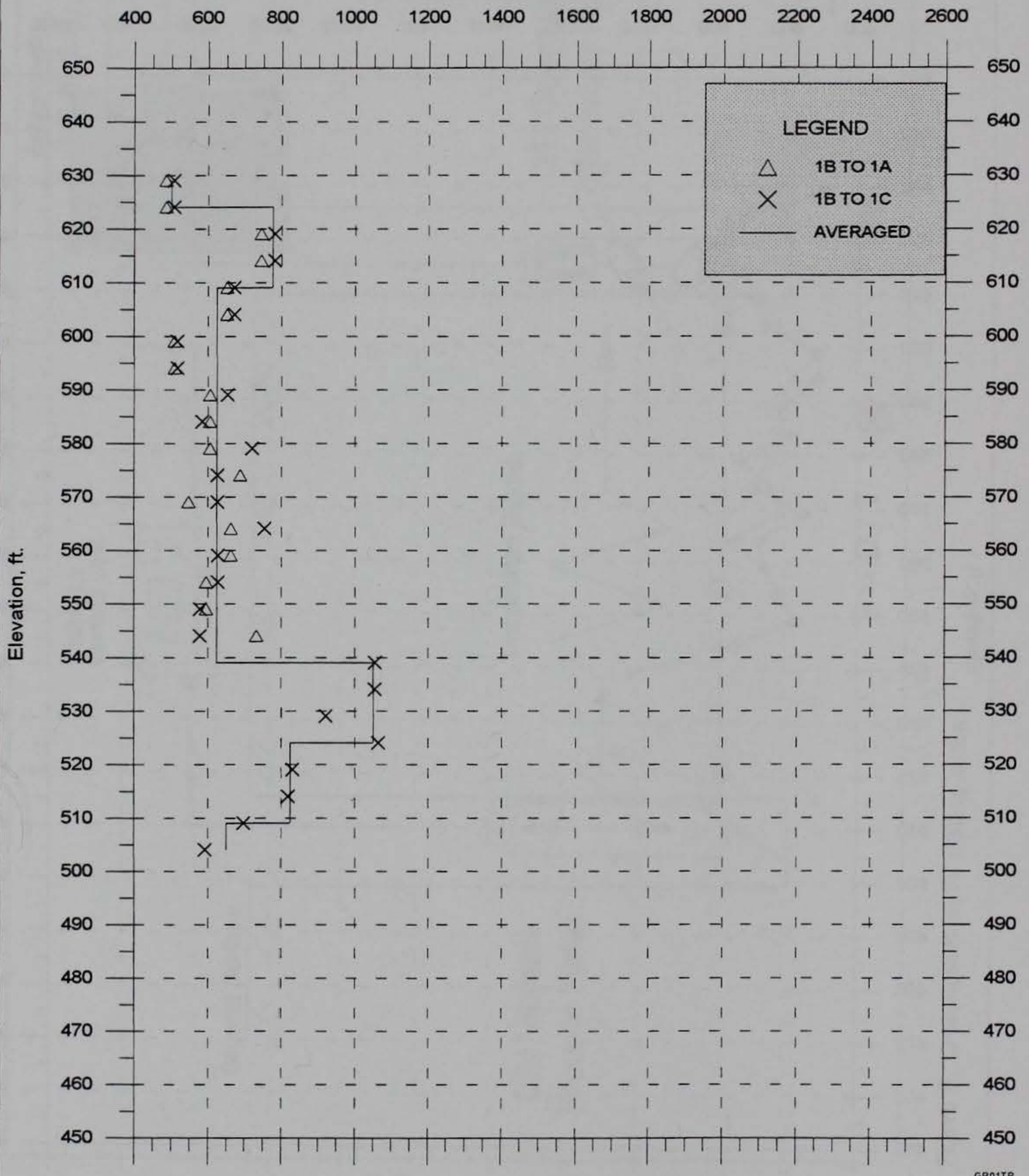

Figure 8. Computed true crosshole S-wave velocities, boring set GP01, upstream service road, Sta. $28+80$ 


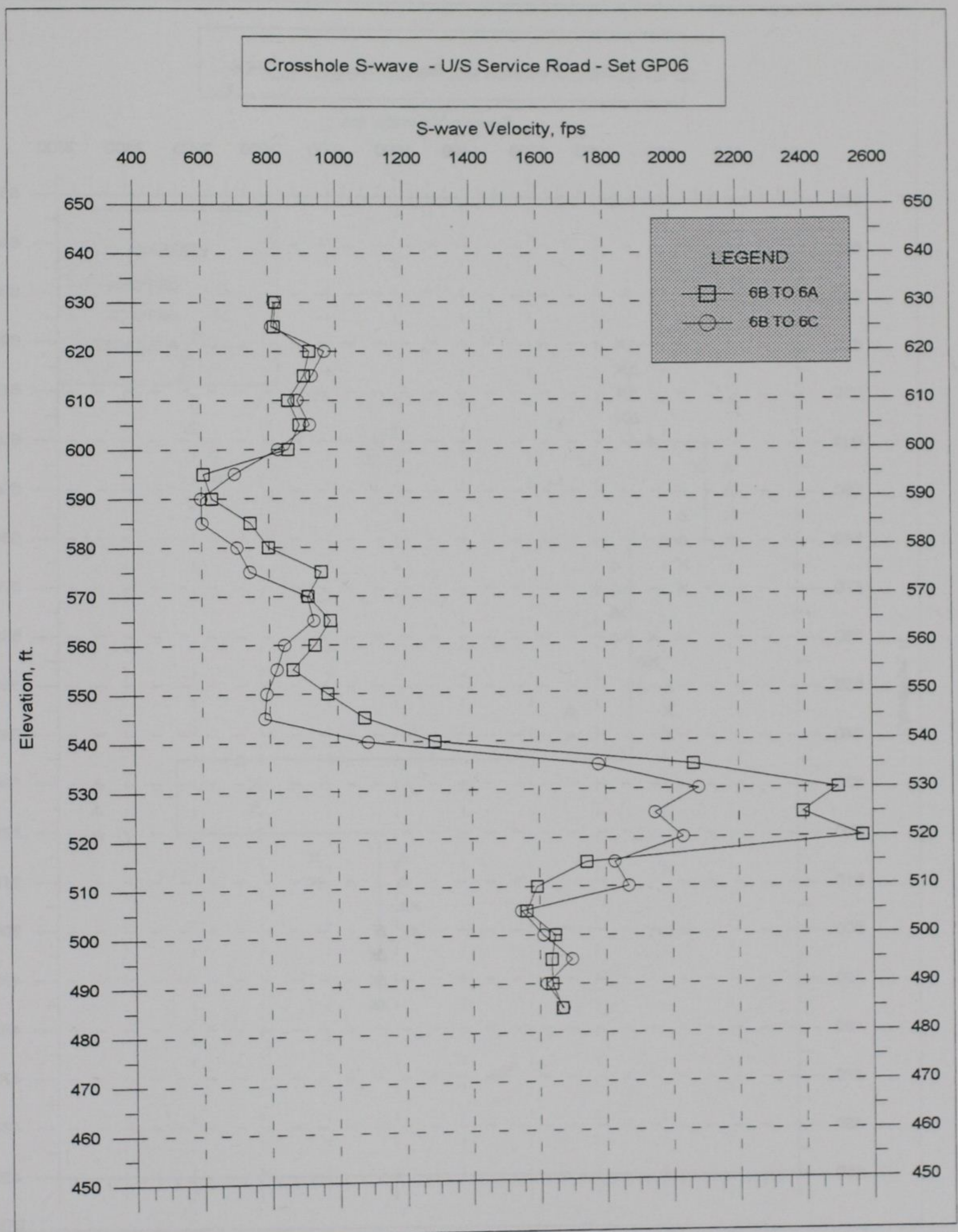

Figure 9. Apparent crosshole S-wave velocities, boring set GP06, upstream service road, Sta. $31+70$ 




Figure 10. Computed true crosshole S-wave velocities, boring set GP06, upstream service road, Sta. $31+70$ 


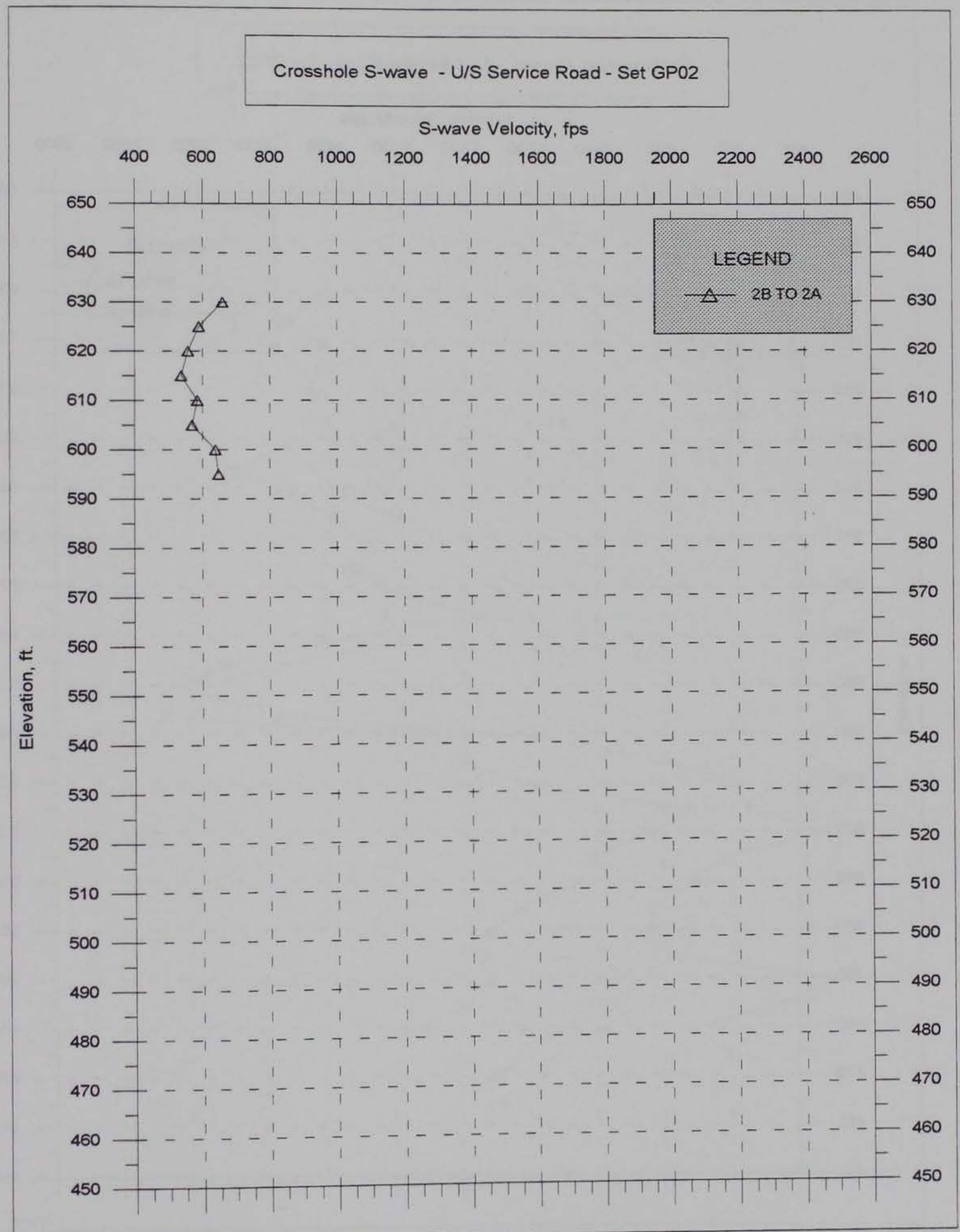

Figure 11. Apparent crosshole S-wave velocities, boring set GP02, upstream service road, Sta. $33+00$ 


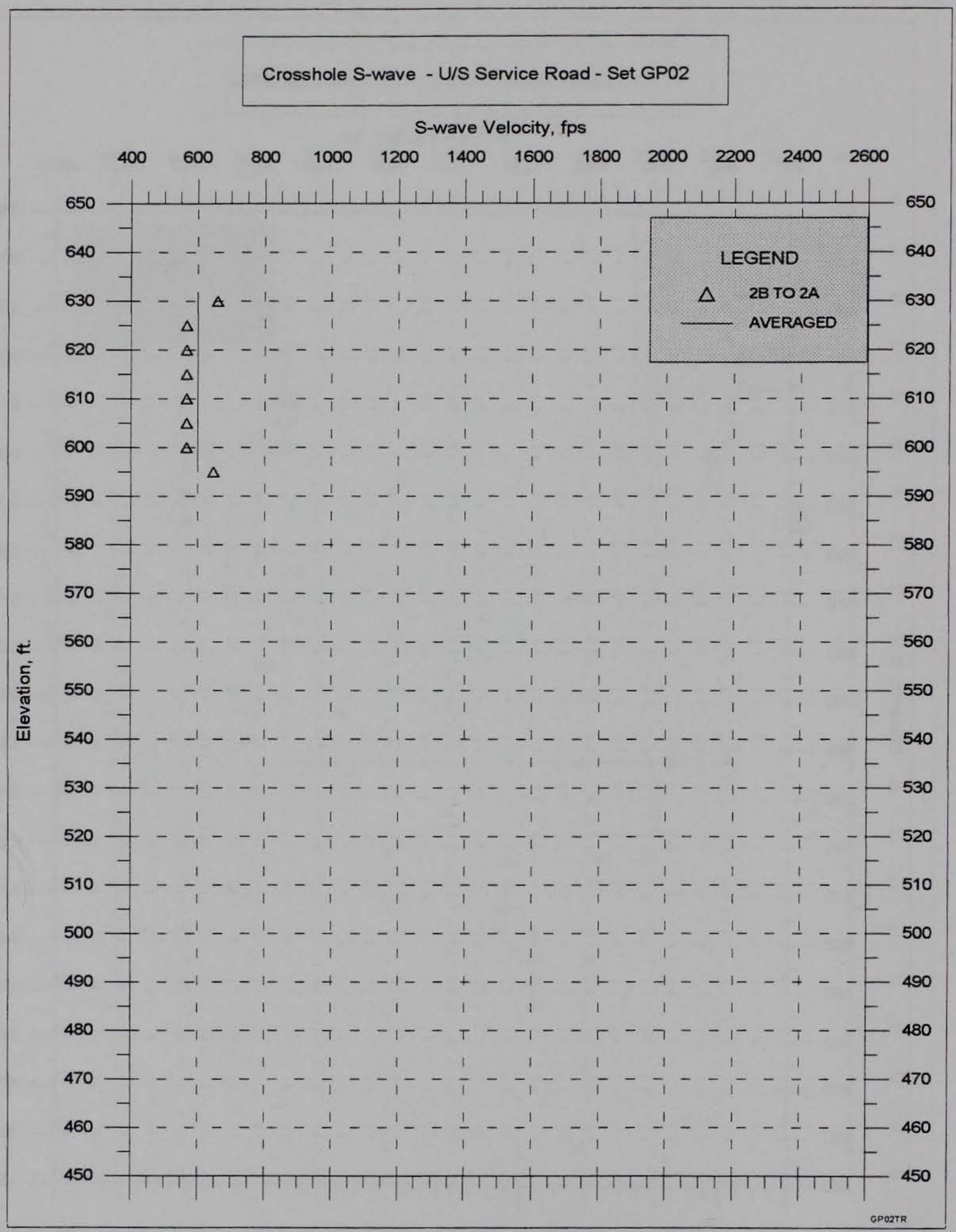

Figure 12. Computed true crosshole S-wave velocities, boring set GP02, upstream service road, Sta. $33+00$ 


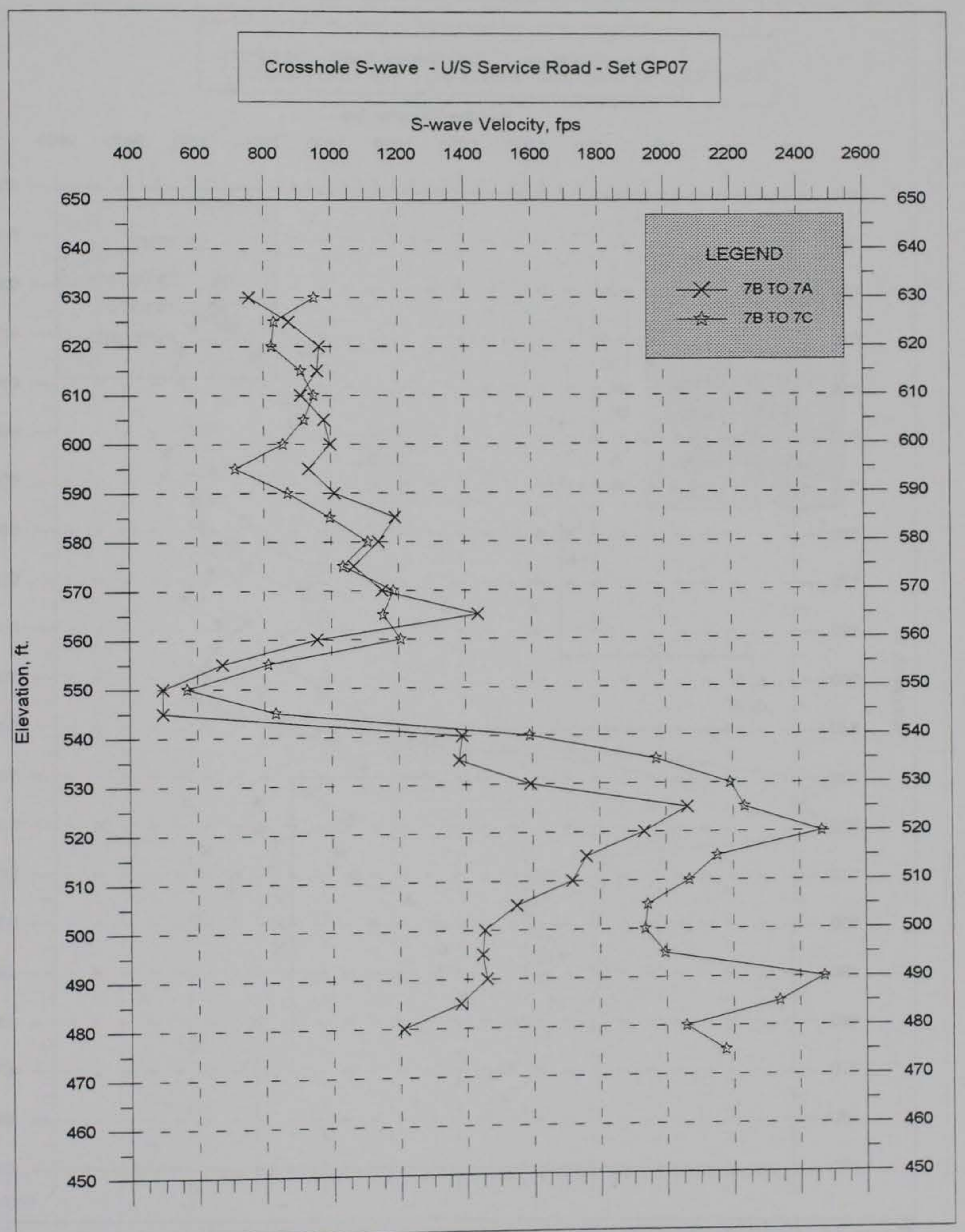

Figure 13. Apparent crosshole S-wave velocities, boring set GP07, upstream service road, Sta. $37+80$ 


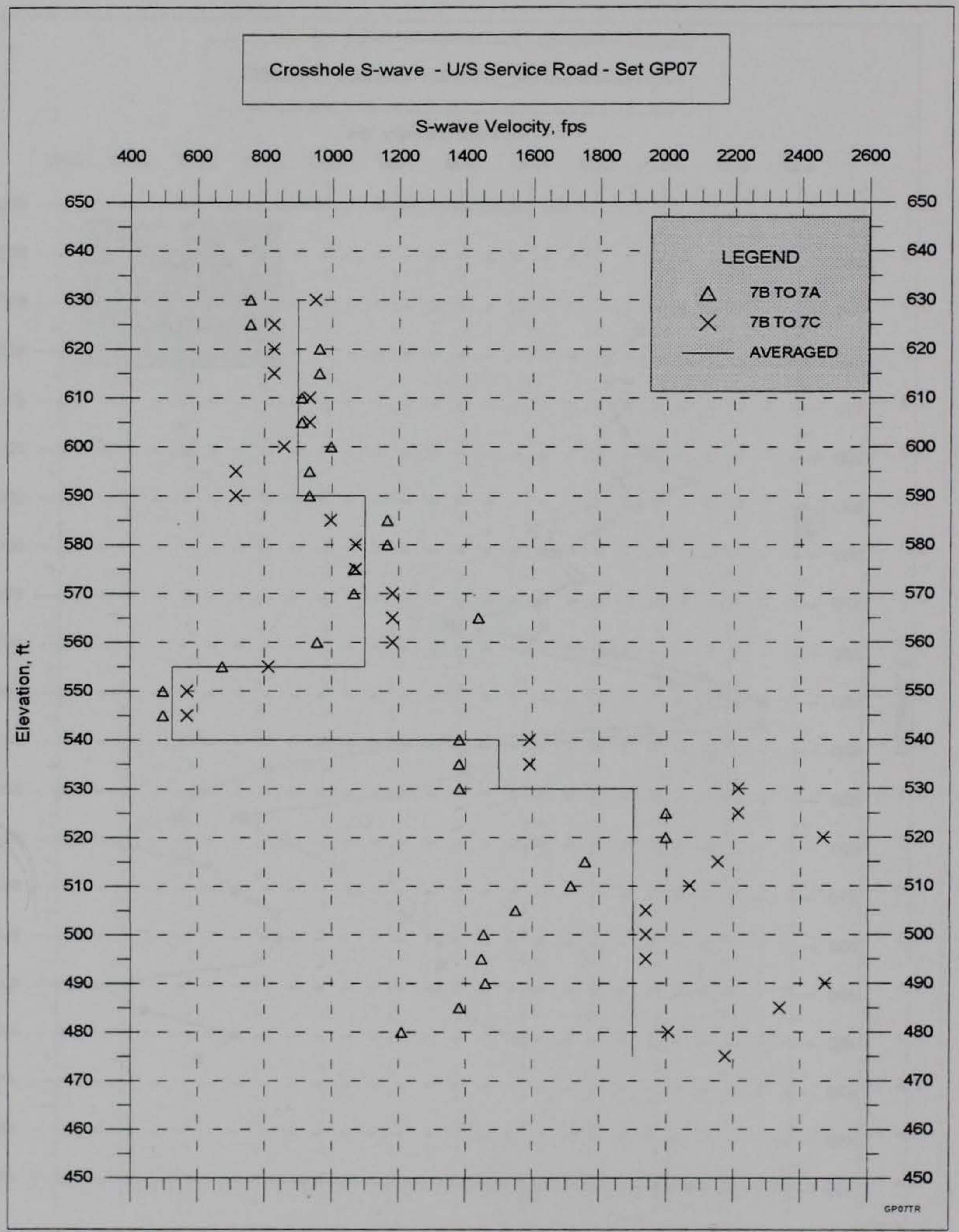

Figure 14. Computed true crosshole S-wave velocities, boring set GP07, upstream service road, Sta. $37+80$ 


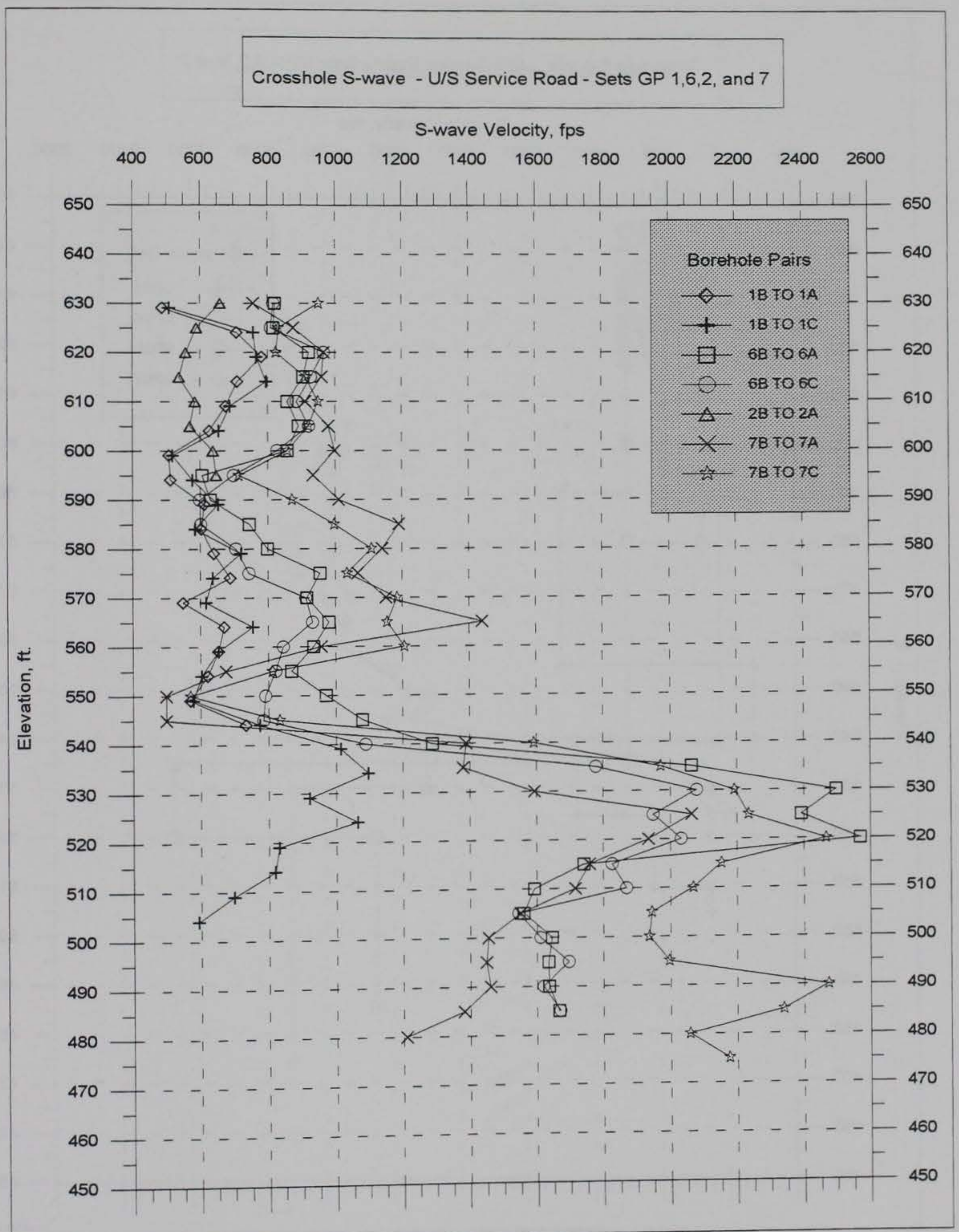

Figure 15. Apparent crosshole S-wave velocities, boring sets GP01, GP06, GP02, and GP07, upstream service road 


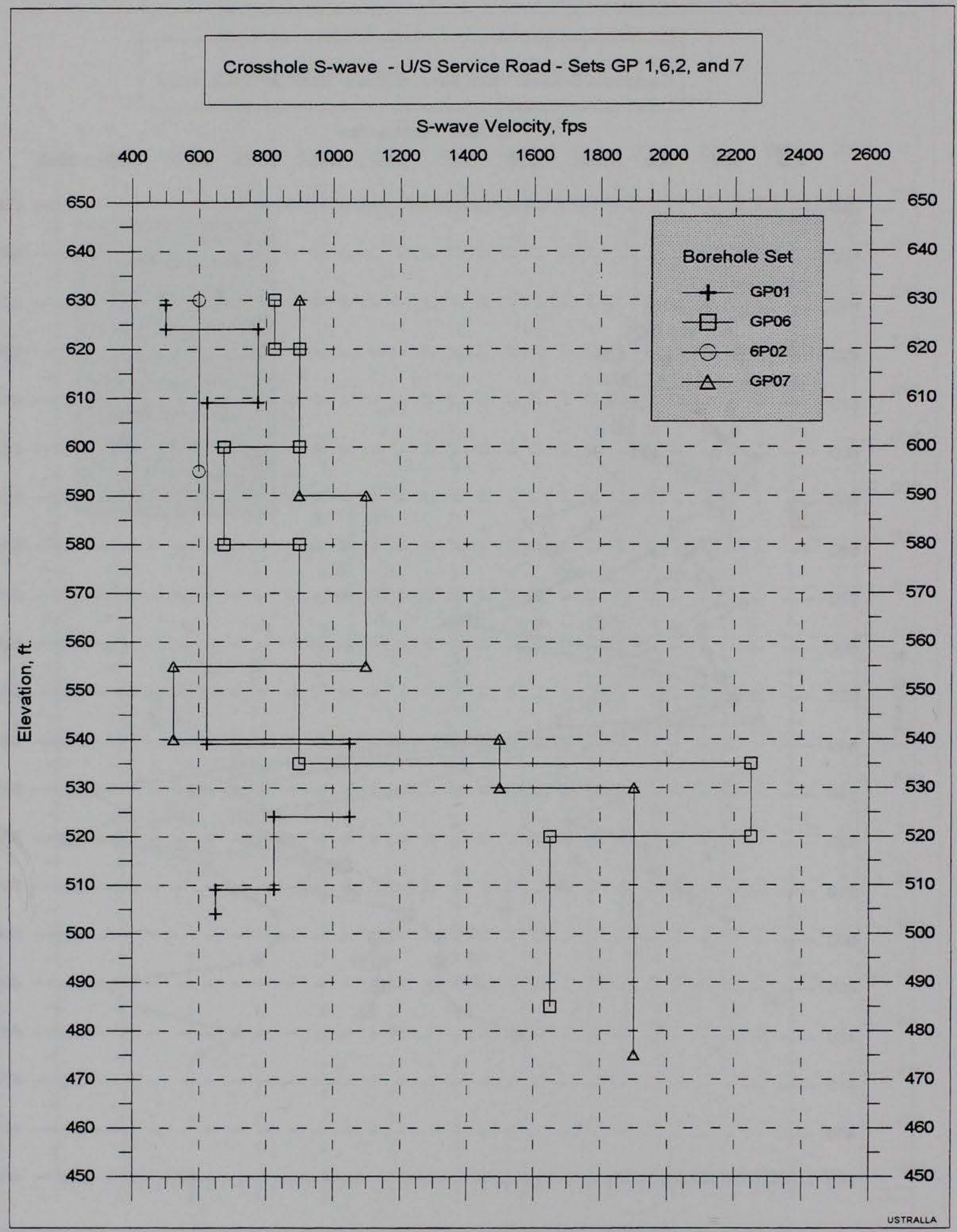

Figure 16. Computed true crosshole S-wave velocities, boring sets GP01, GP06, GP02, and GP07, upstream service road 


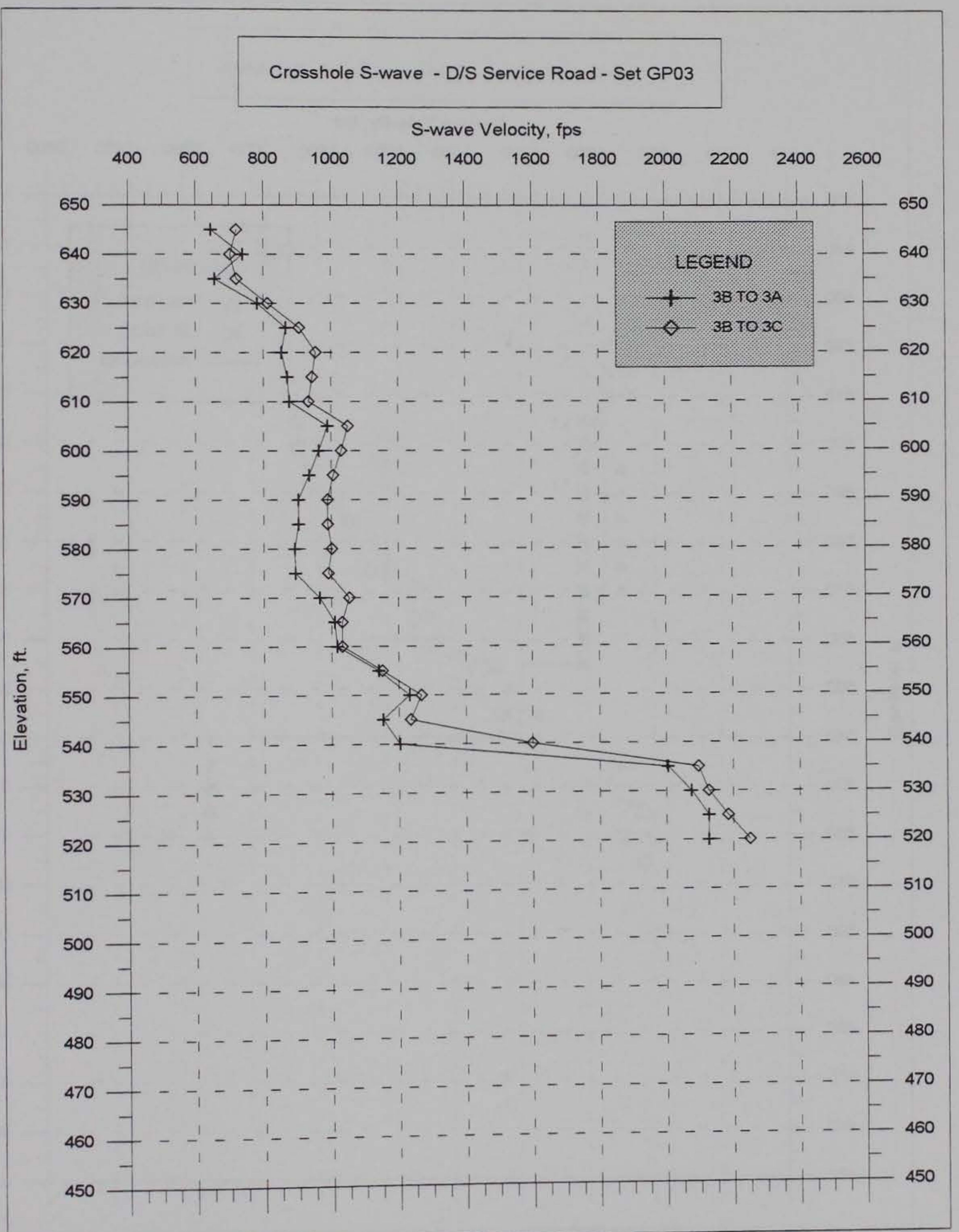

Figure 17. Apparent crosshole S-wave velocities, boring set GP03,

Downstream service road, Sta. $28+80$ 


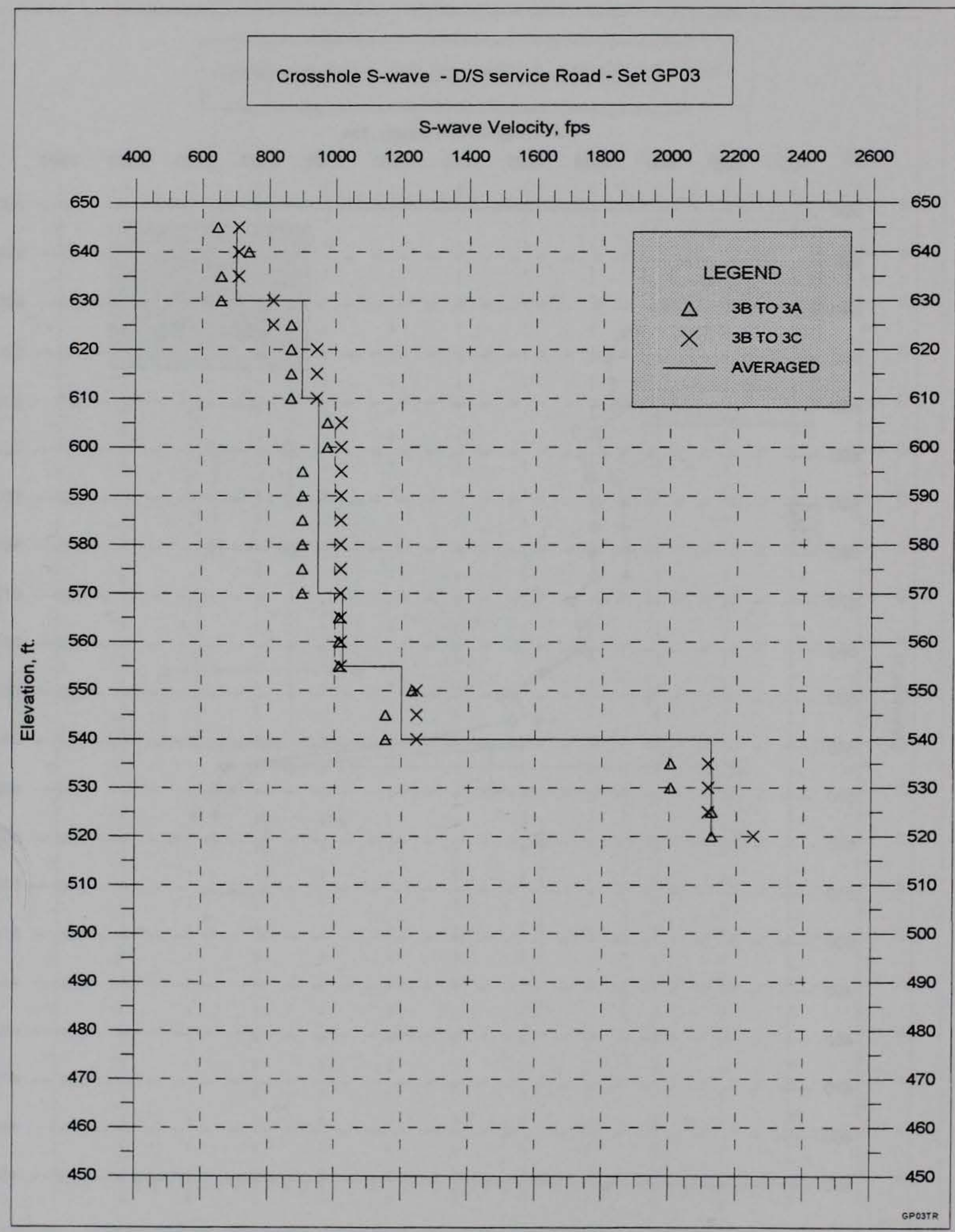

Figure 18. Computed true crosshole S-wave velocities, boring set GP03, downstream service road, Sta. $28+80$ 


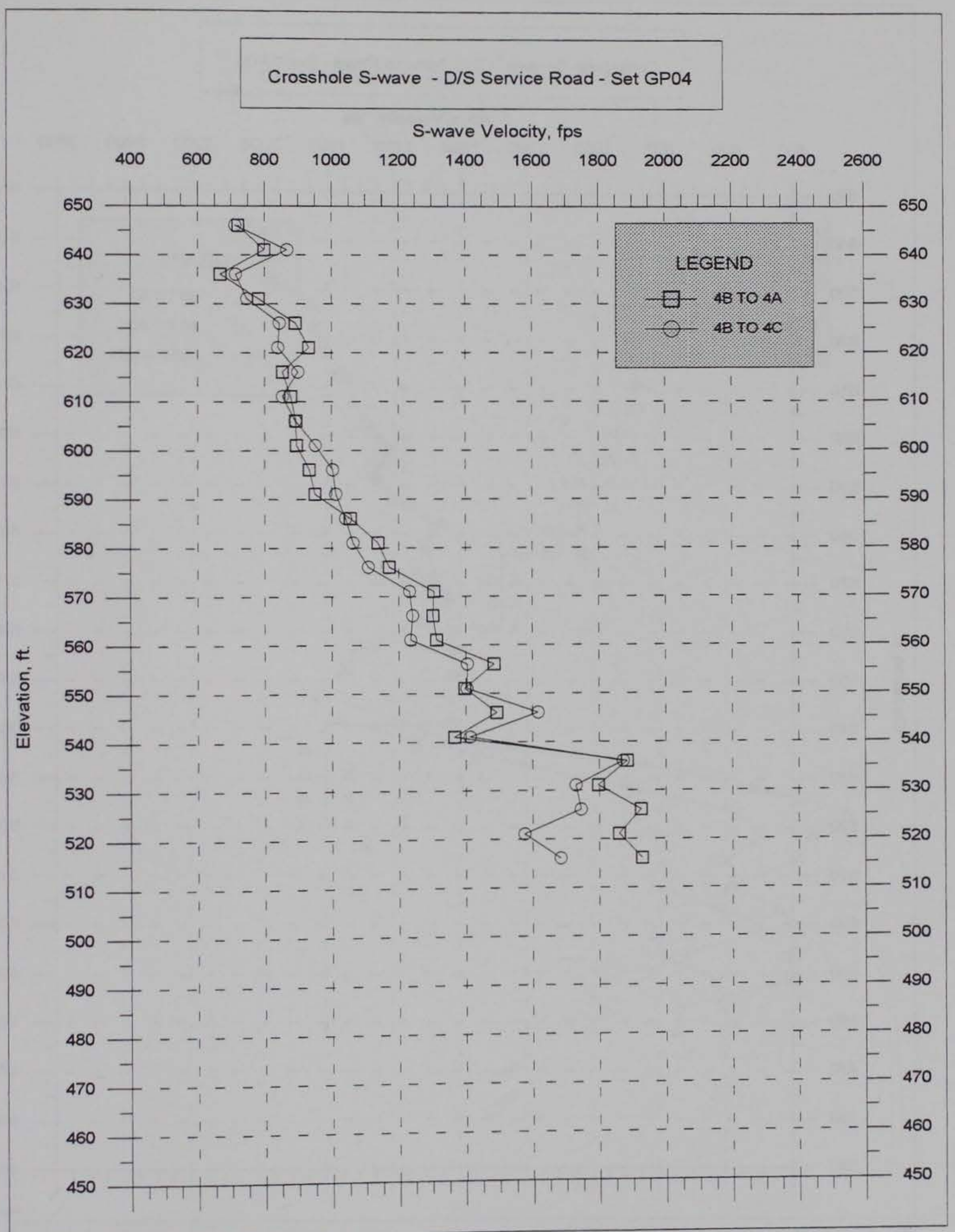

Figure 19. Apparent crosshole S-wave velocities, boring set GP04, downstream service road, Sta. $33+40$ 


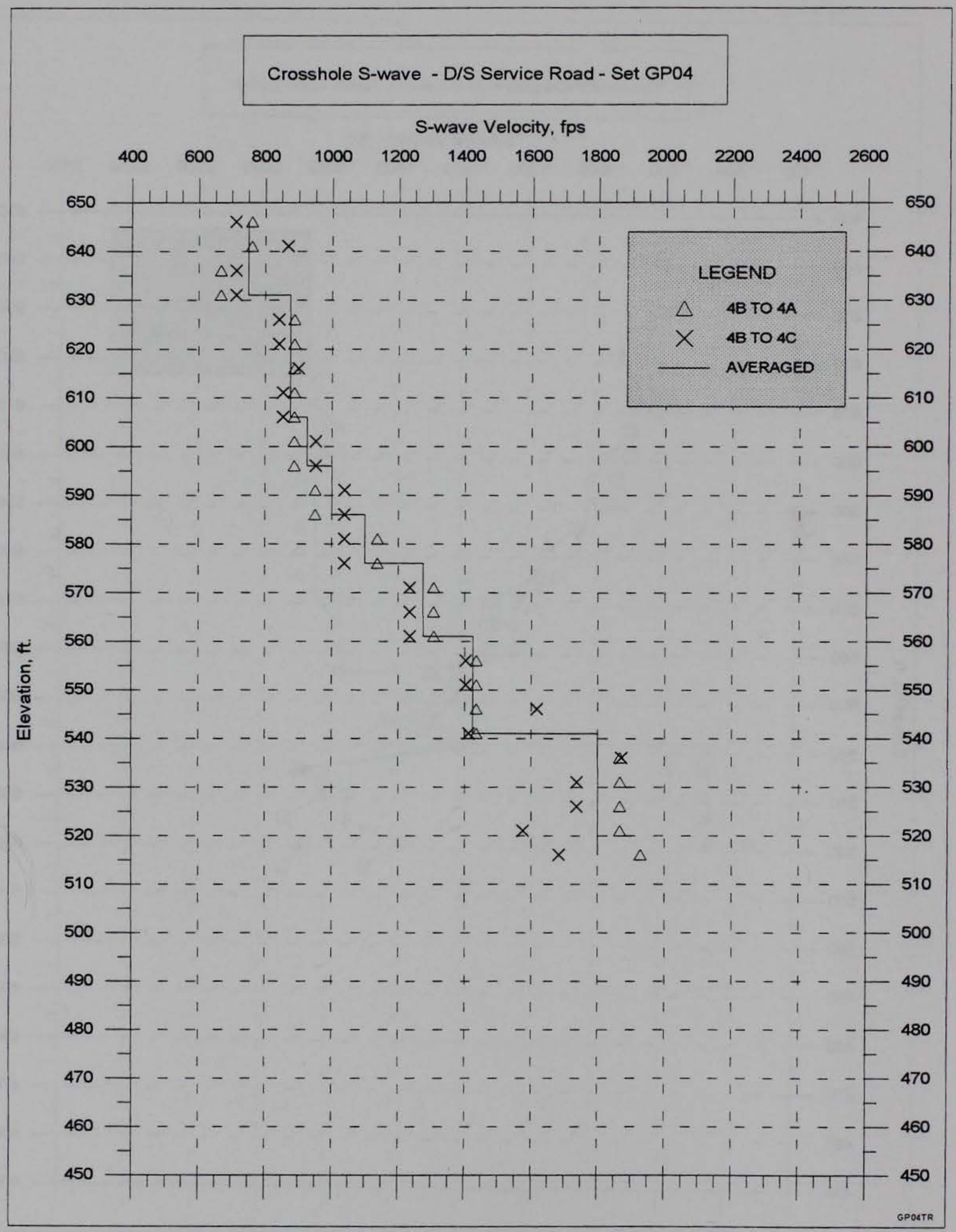

Figure 20. Computed true crosshole S-wave velocities, boring set GP04, downstream service road, Sta. $33+40$ 


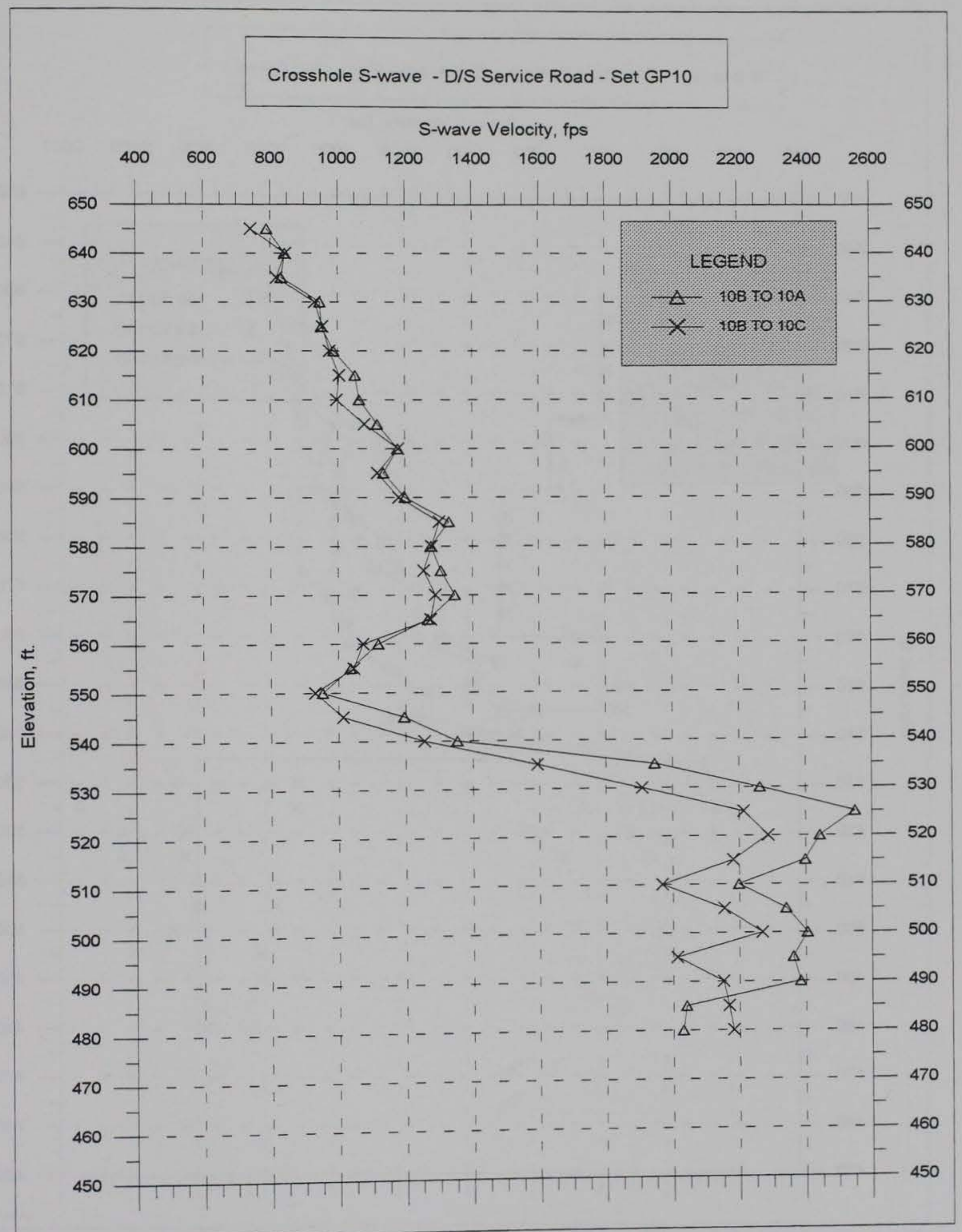

Figure 21. Apparent crosshole S-wave velocities, boring set GP10, downstream service road, Sta. $38+20$ 


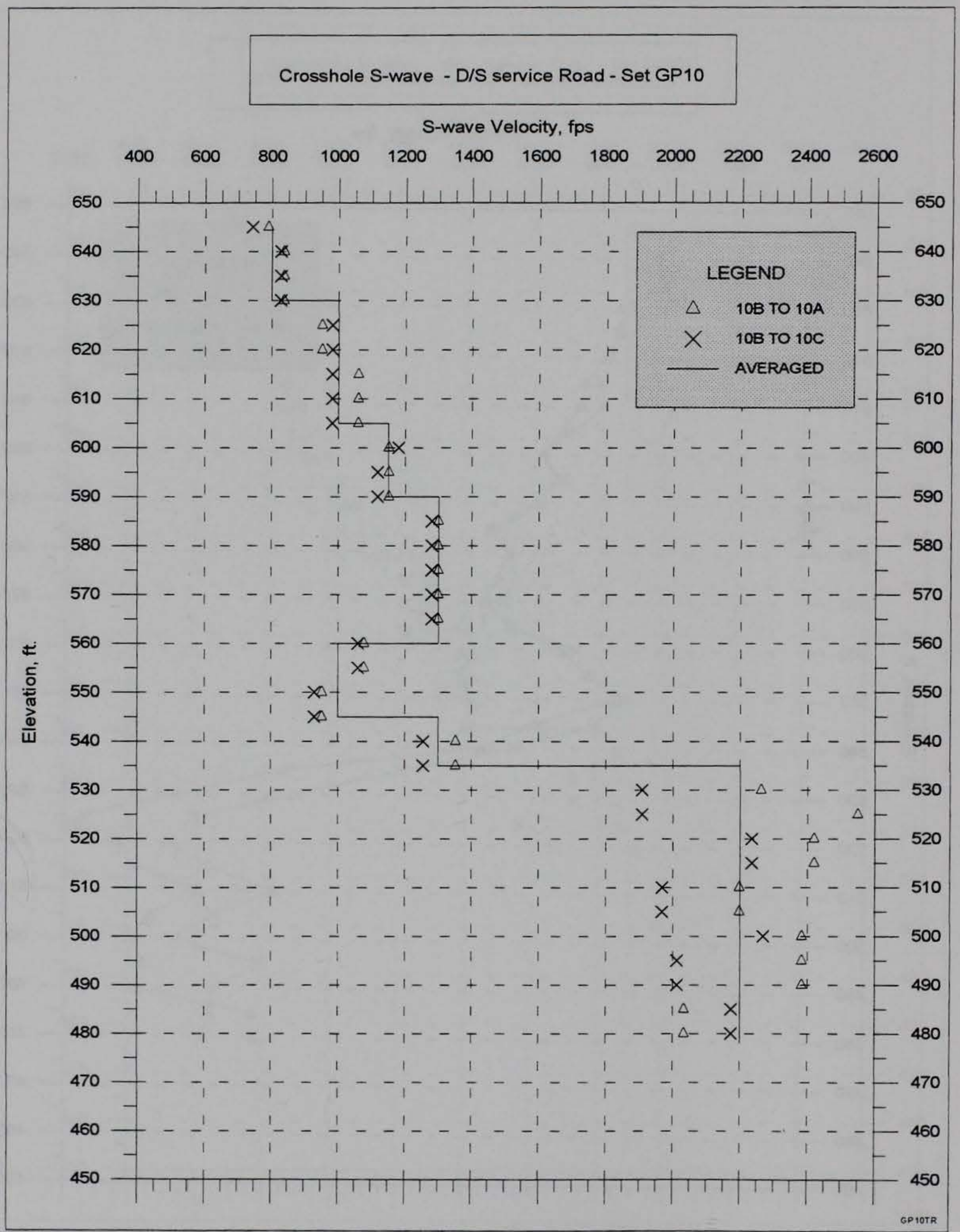

Figure 22. Computed true crosshole S-wave velocities, boring set GP10, downstream service road, Sta. $38+20$ 


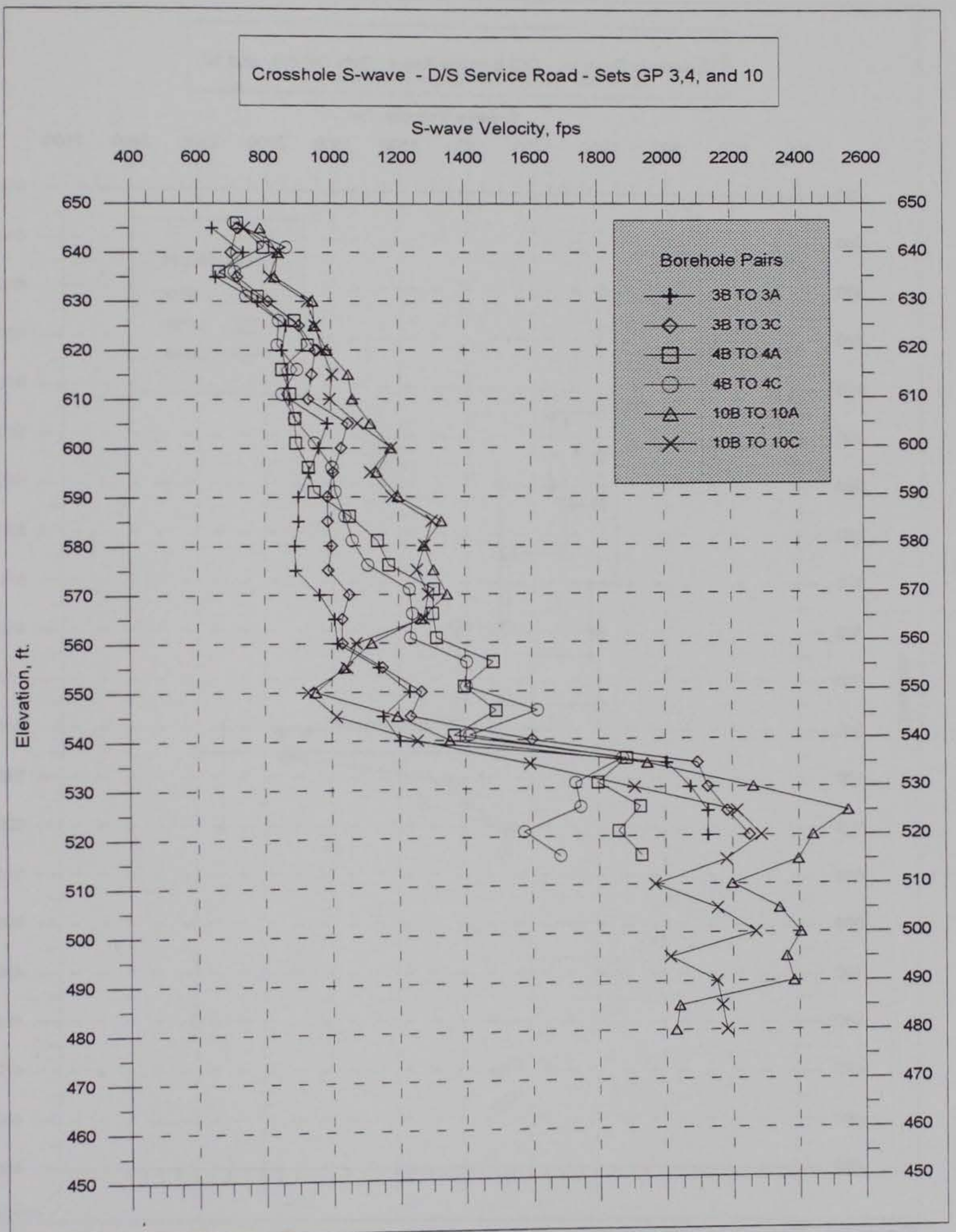

Figure 23. Apparent crosshole S-wave velocities, boring sets GP03, GP04, and GP10, downstream service road 


\section{Crosshole S-wave - D/S Service Road - Sets GP 3,4, and 10}

S-wave Velocity, fps

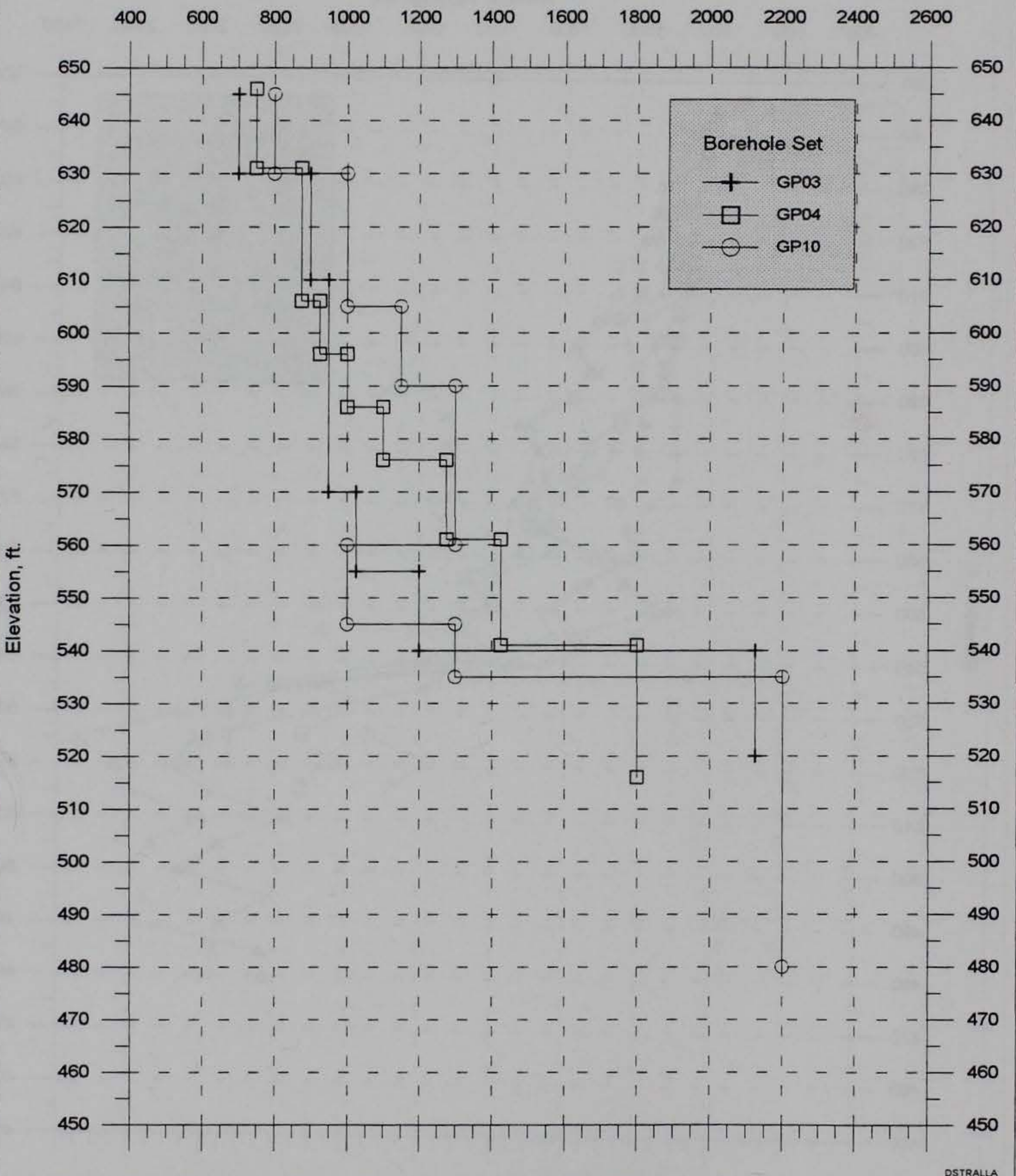

Figure 24. Computed true crosshole S-wave velocities, boring sets GP03, GP04, and GP10, downstream service road 


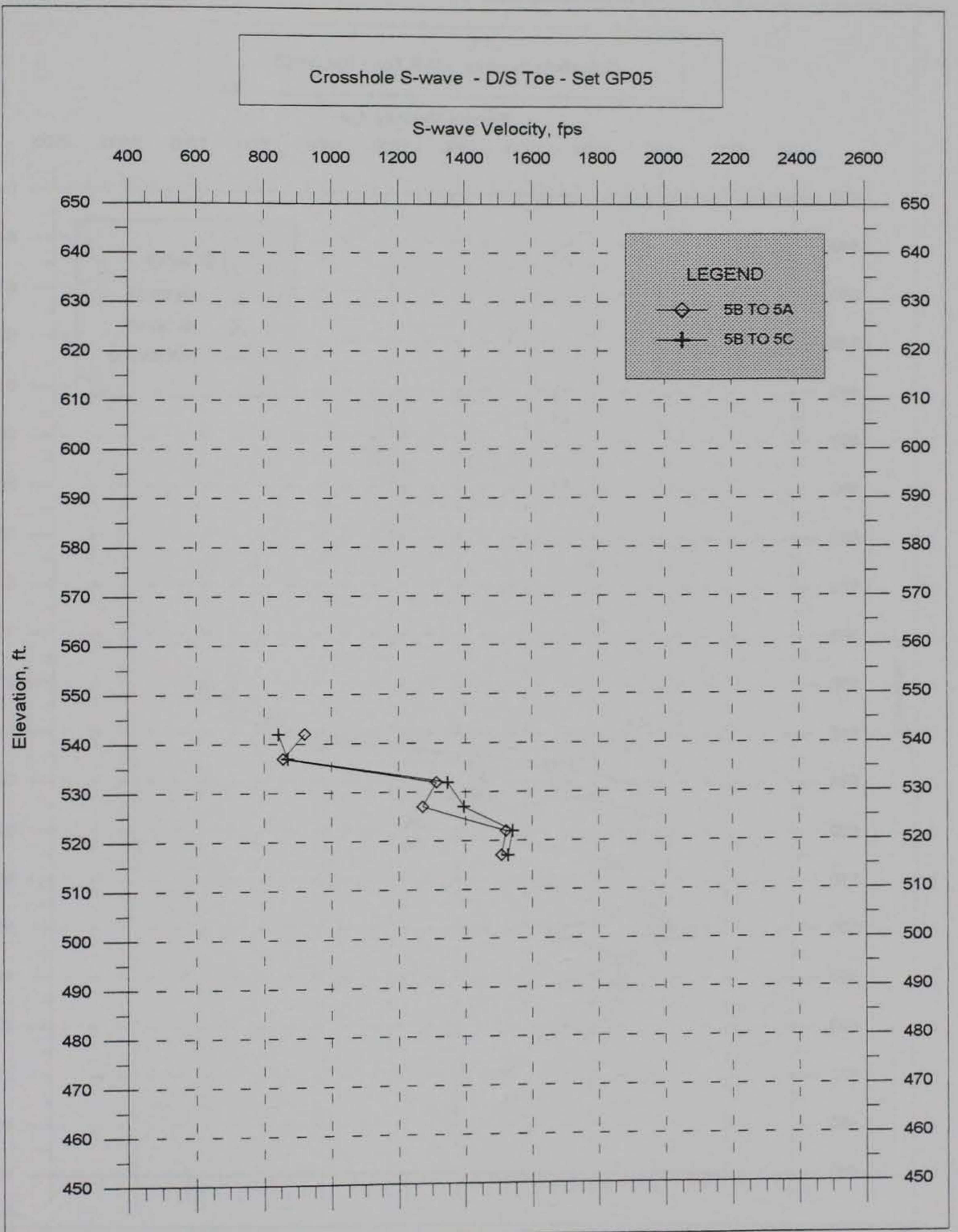

Figure 25. Apparent crosshole S-wave velocities, boring set GP05, downstream toe, Sta. $33+10$ 


\section{Crosshole S-wave - D/S Toe - Set GP05}

S-wave Velocity, fps



Figure 26. Computed true crosshole S-wave velocities, boring set GP05, downstream toe, Sta. $33+10$ 


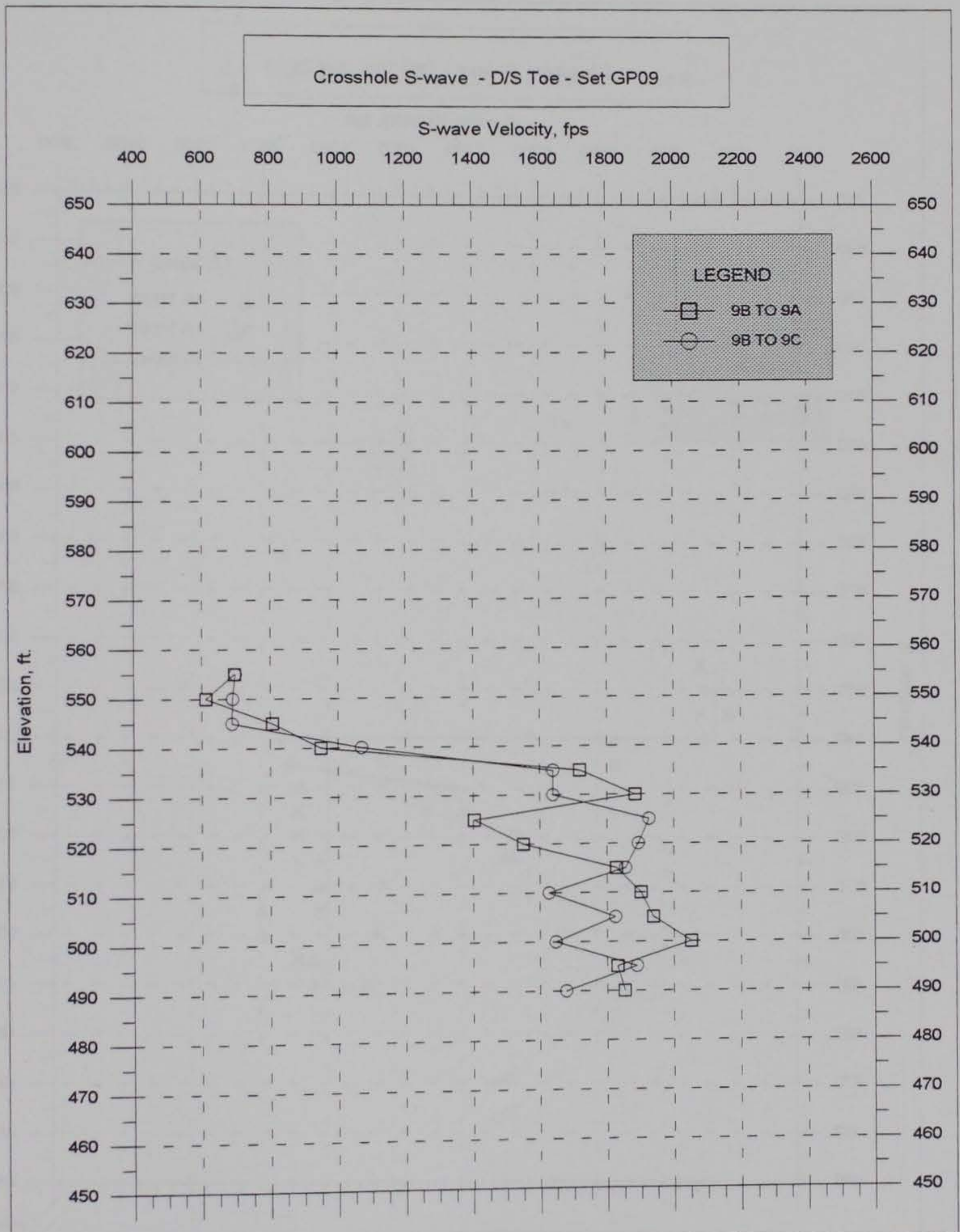

Figure 27. Apparent crosshole S-wave velocities, boring set GP09, downstream toe, Sta. $37+70$ 


\section{Crosshole S-wave - D/S Toe - Set GP09}

S-wave Velocity, fps

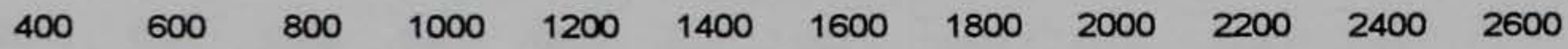

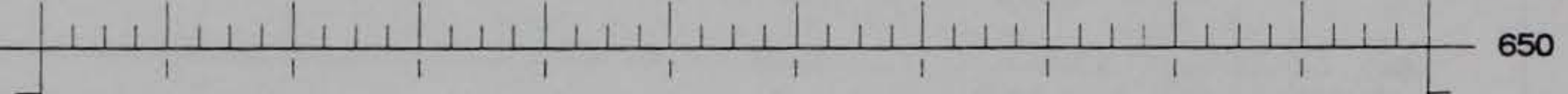

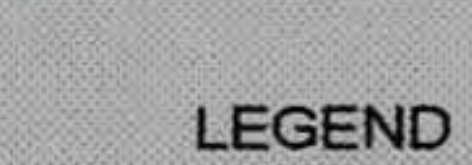

$\triangle \quad 9 B T O 9 A$

$\times \quad 9 B$ TO $9 \mathrm{C}$ AVERAGED 


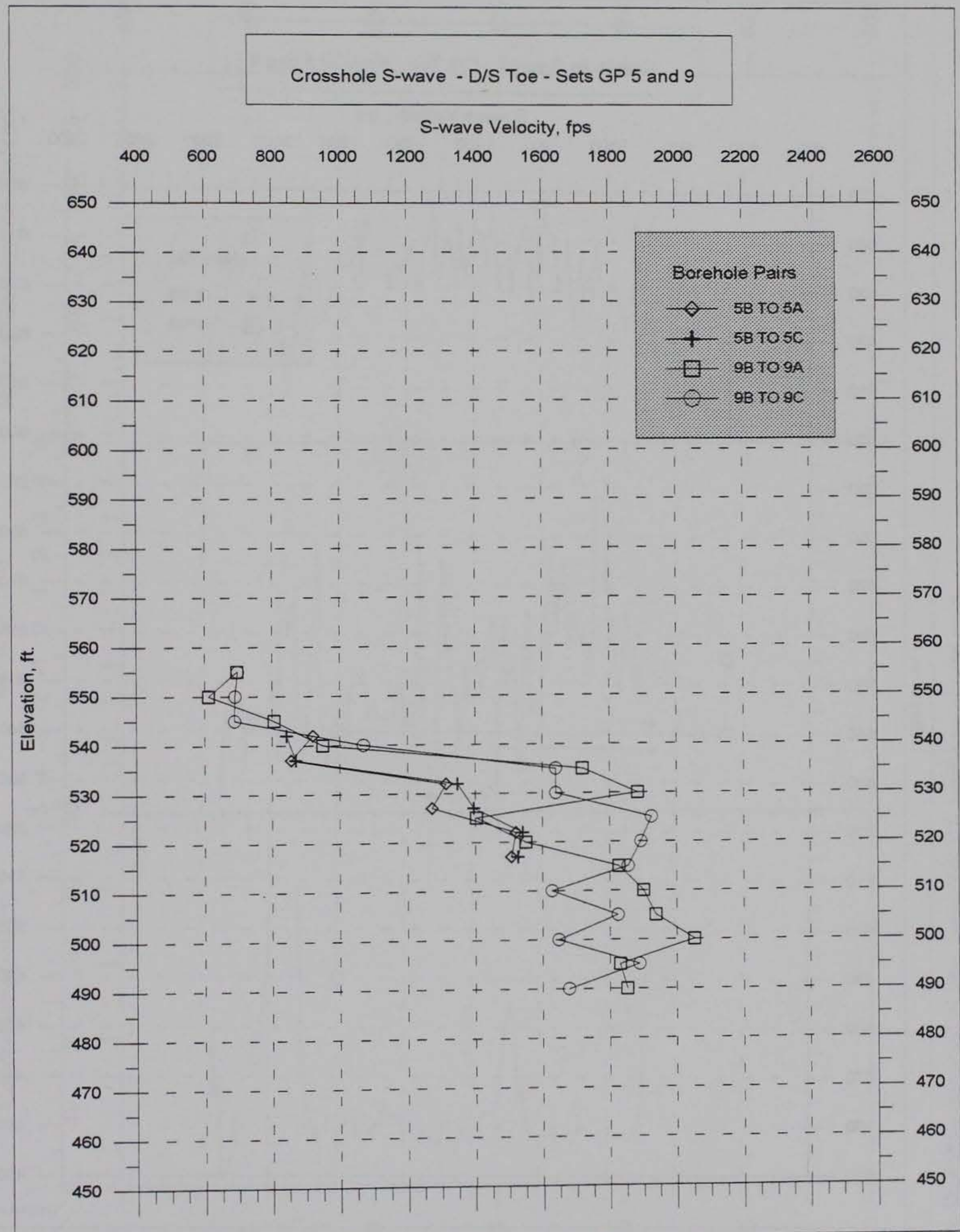

Figure 29. Apparent crosshole S-wave velocities, boring sets GP05 and GP09 downstream toe 


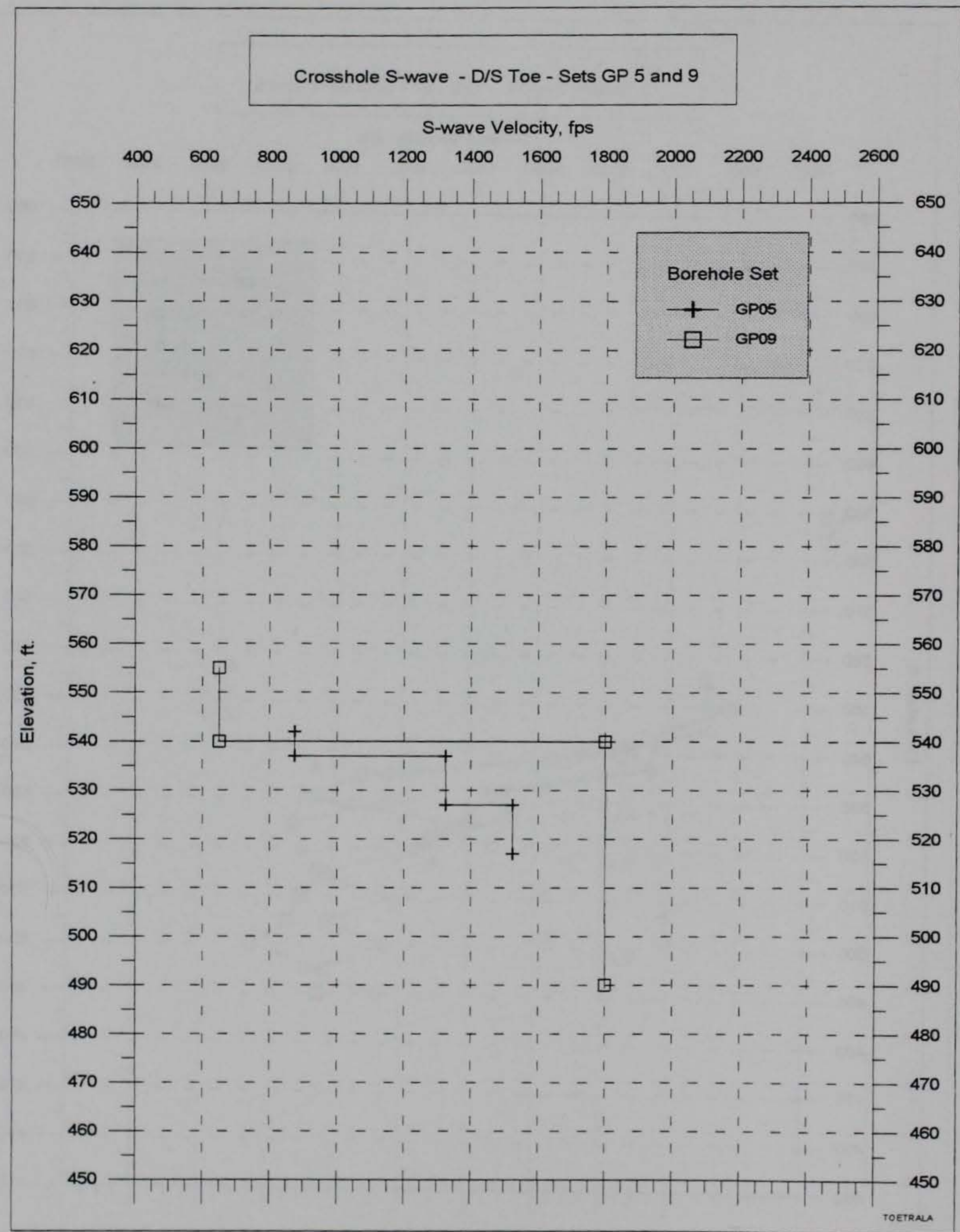

Figure 30. Computed true S-wave velocities, boring sets GP05 and GP09, downstream toe 


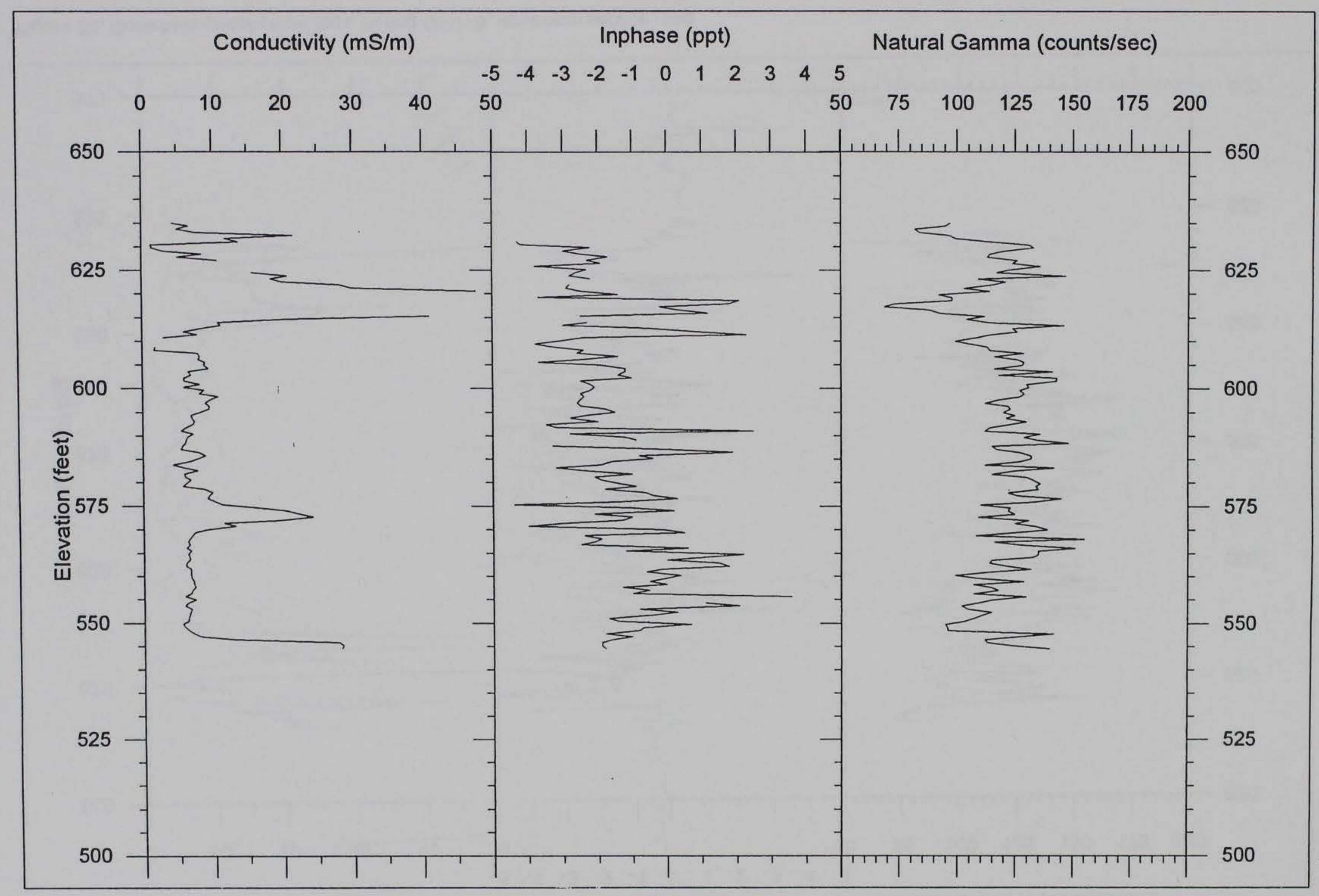

Figure 31. Downhole geophysical logs, boring GP01A, upstream service road 


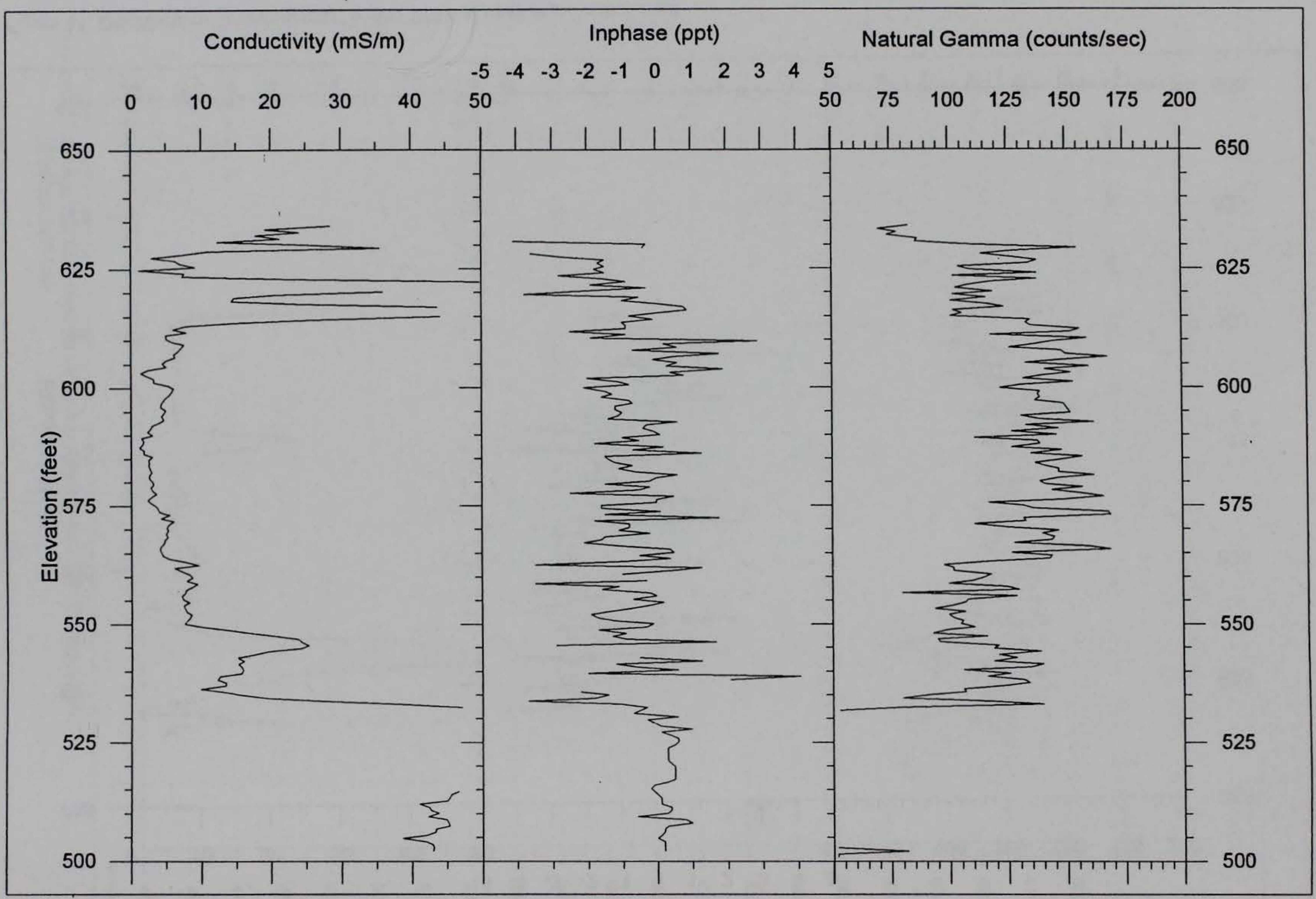

Figure 32. Downhole geophysical logs, boring GP01B, upstream service road 


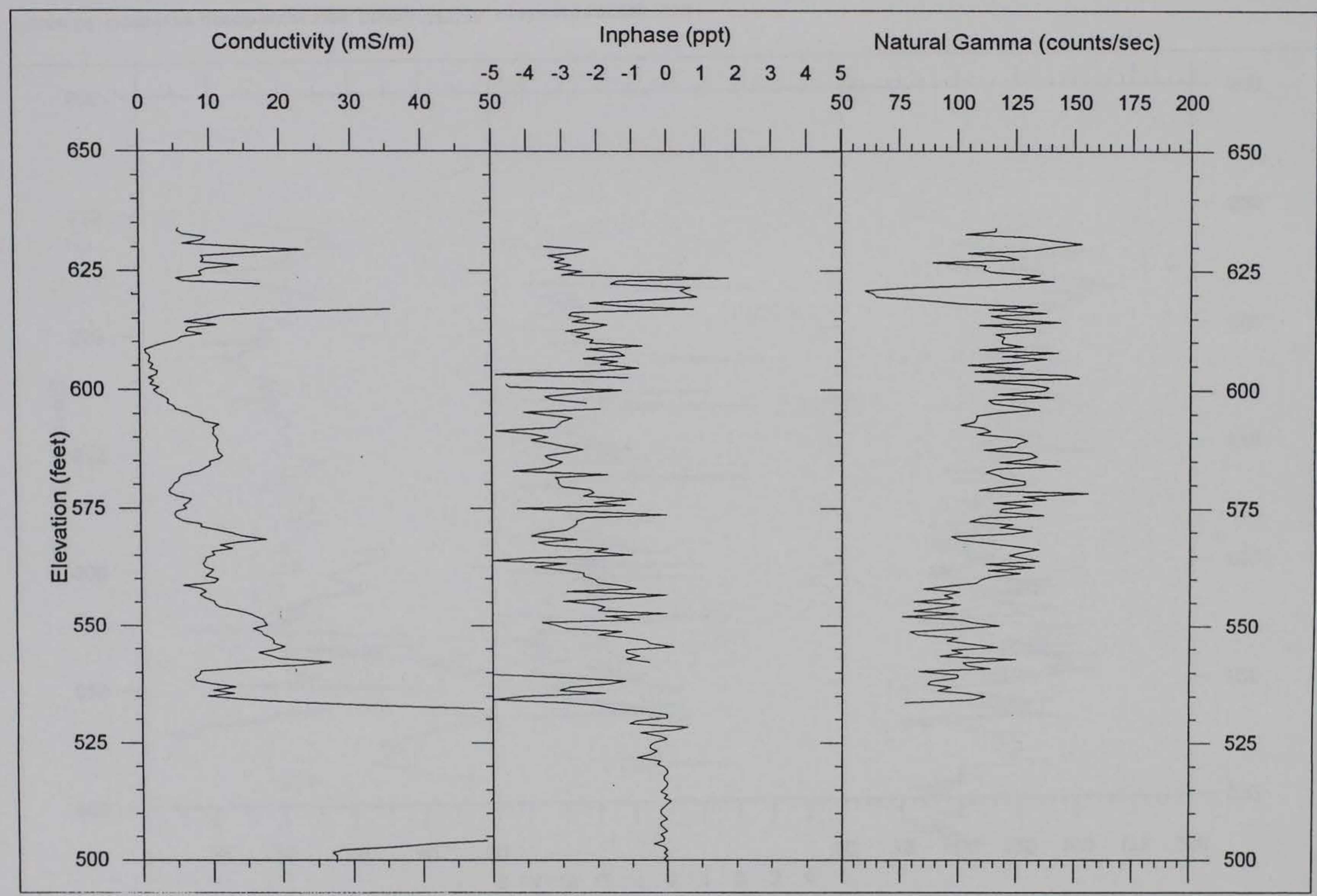

Figure 33. Downhole geophysical logs, boring GP01C, upstream service road 


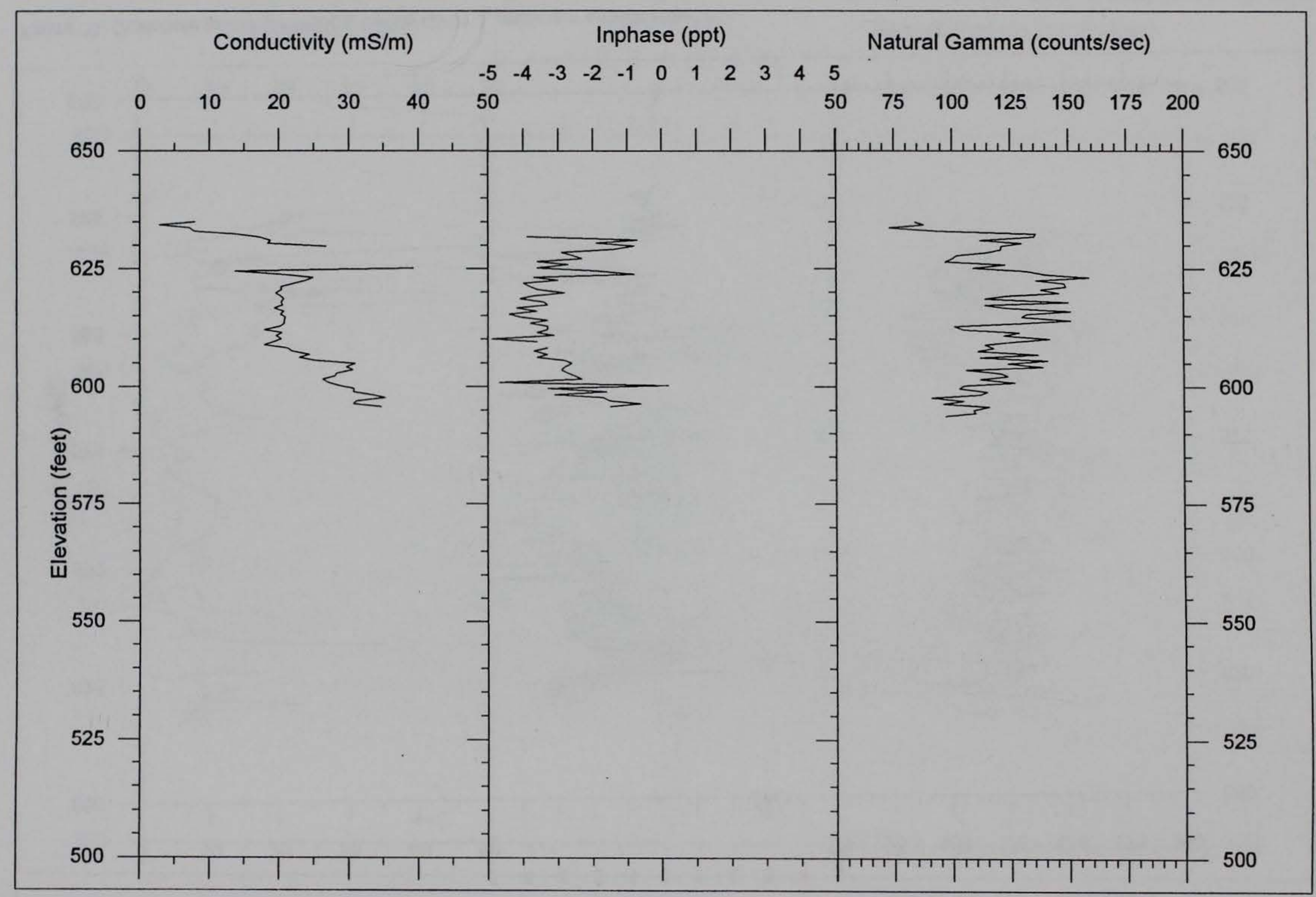

Figure 34. Downhole geophysical logs, boring GP02A, upstream service road 


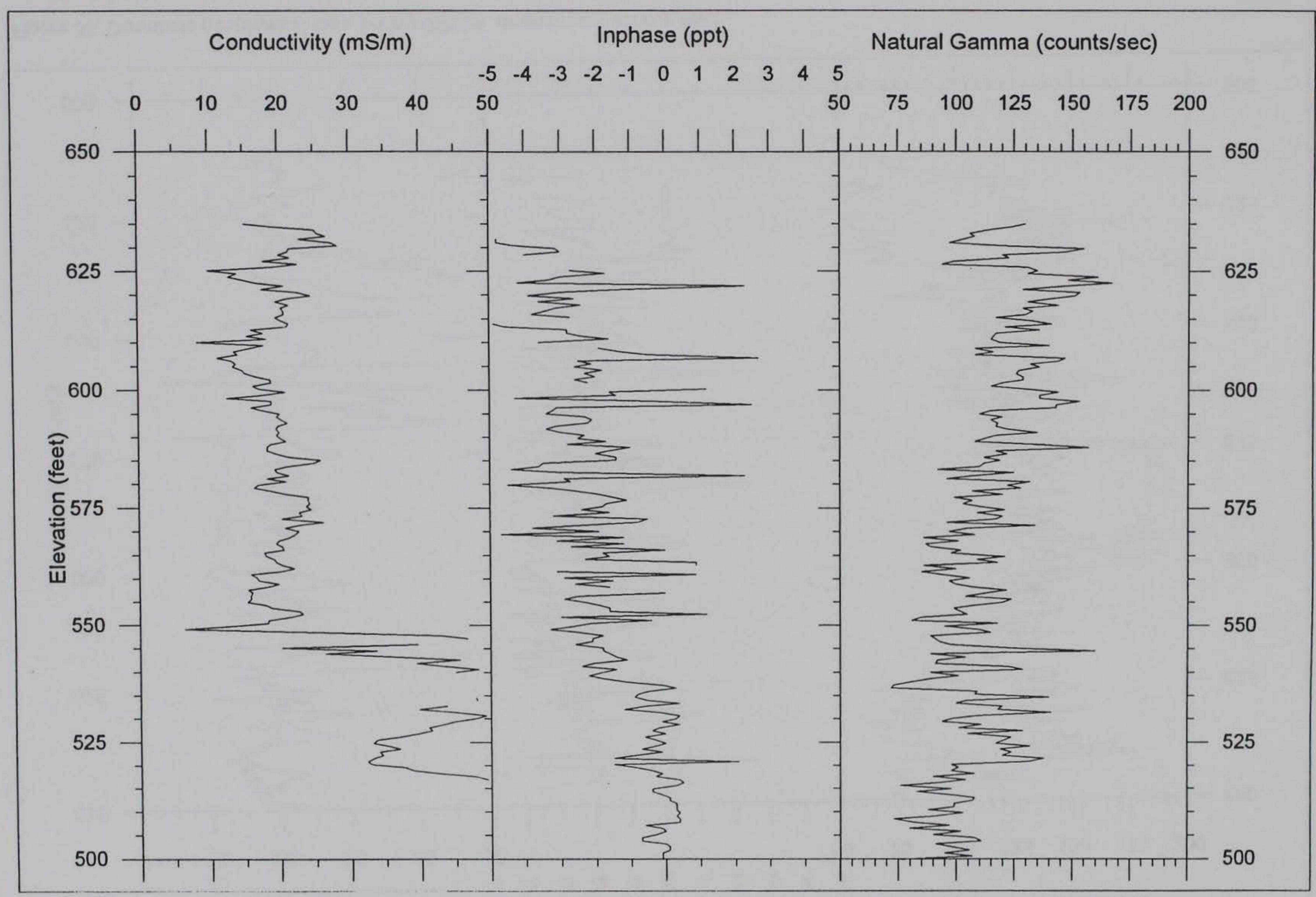

Figure 35. Downhole geophysical logs, boring GP02B, upstream service road 


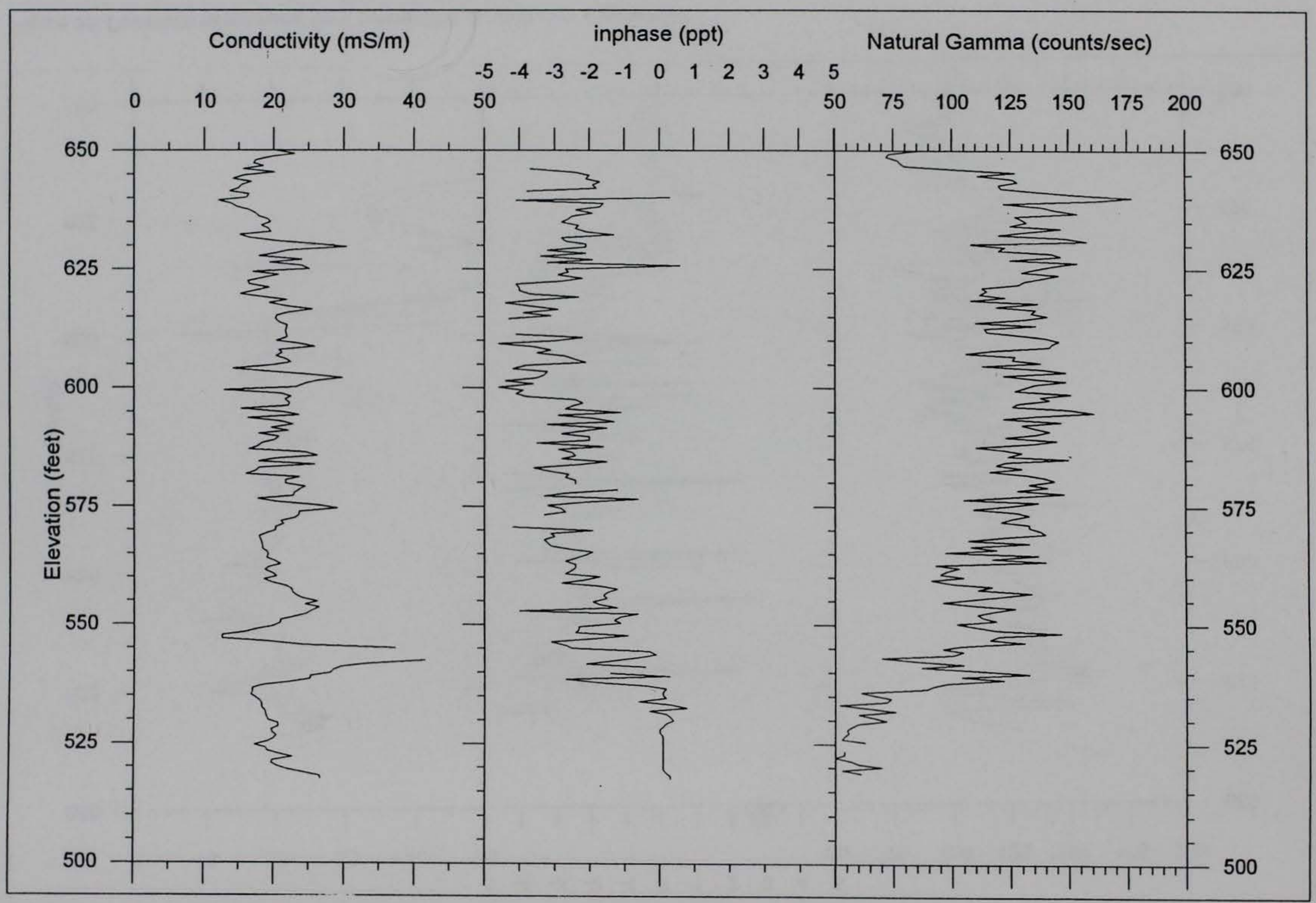

Figure 36. Downhole geophysical logs, boring GP03A, downstream service road 


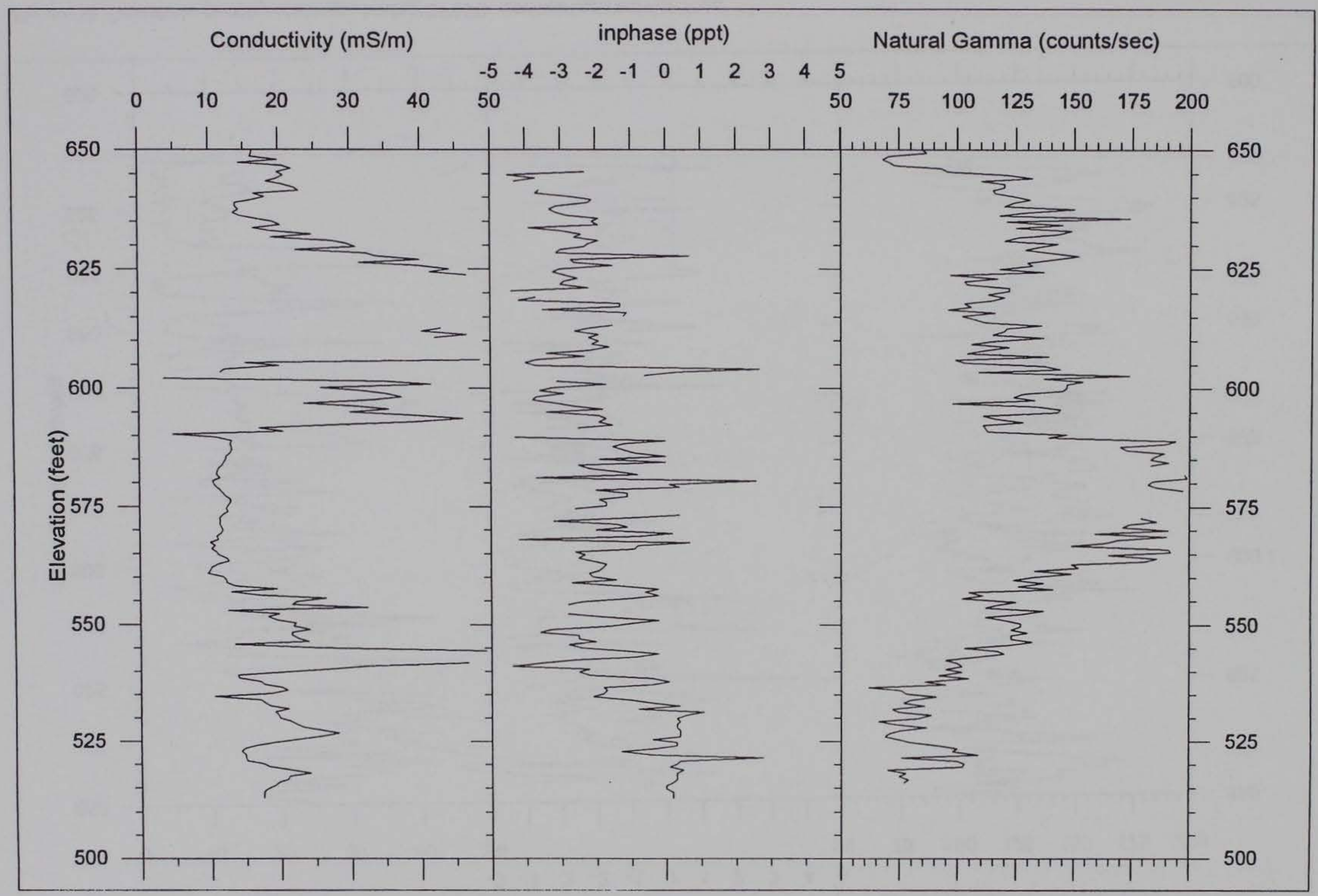

Figure 37. Downhole geophysical logs, boring GP03B, downstream service road 


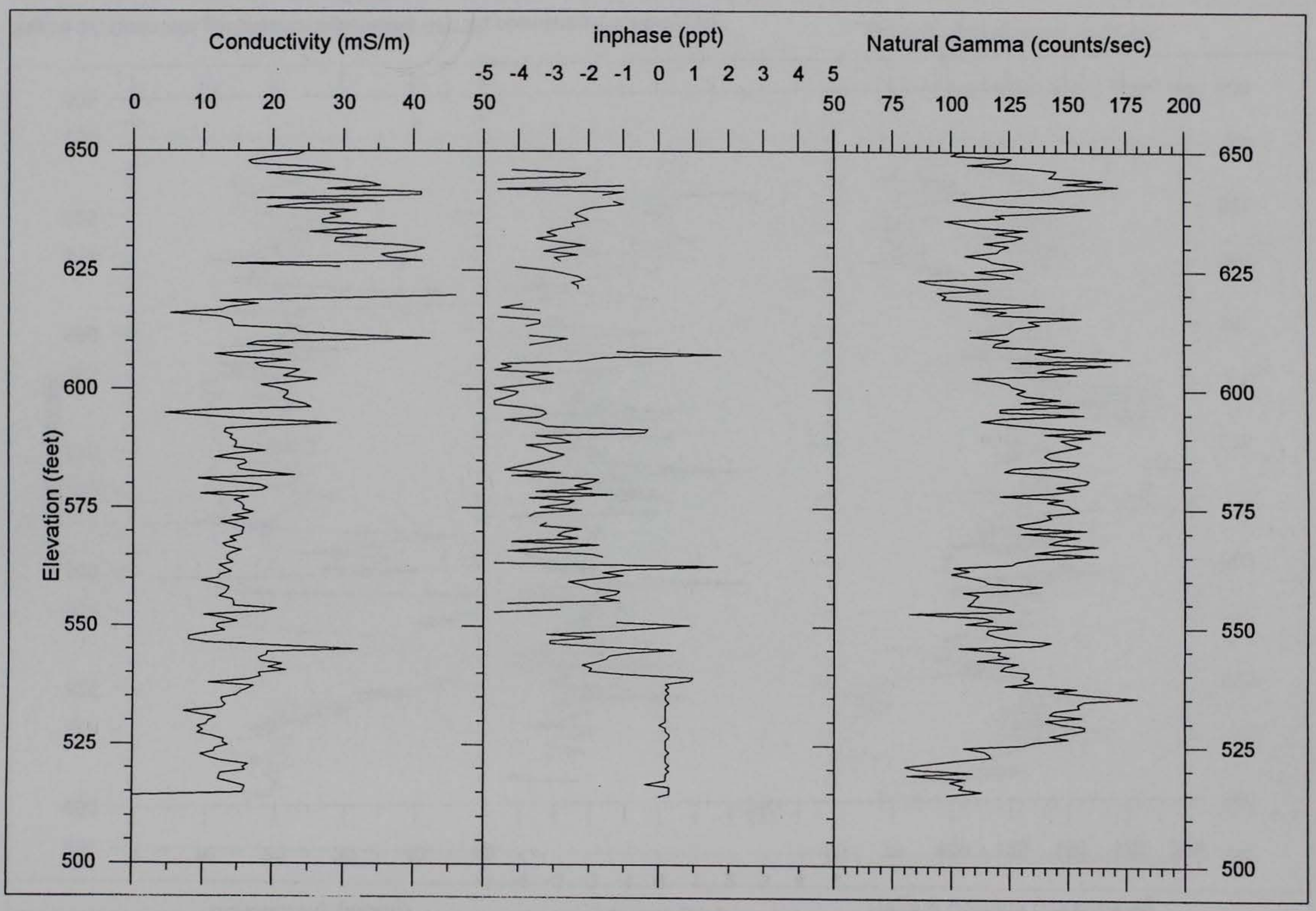

Figure 38. Downhole geophysical logs, boring GP03C, downstream service road 


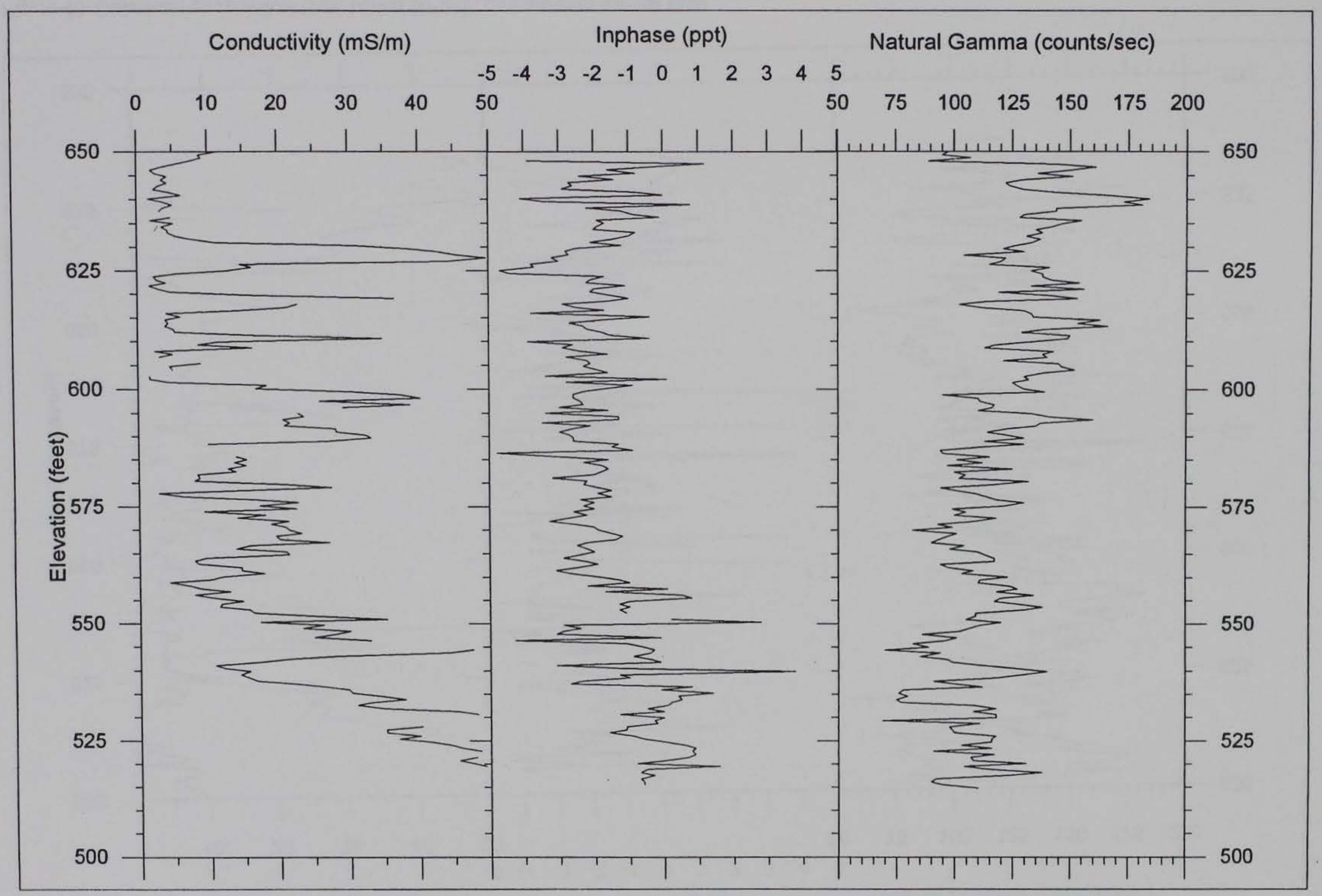

Figure 39. Downhole geophysical logs, boring GP04A, downstream service road 


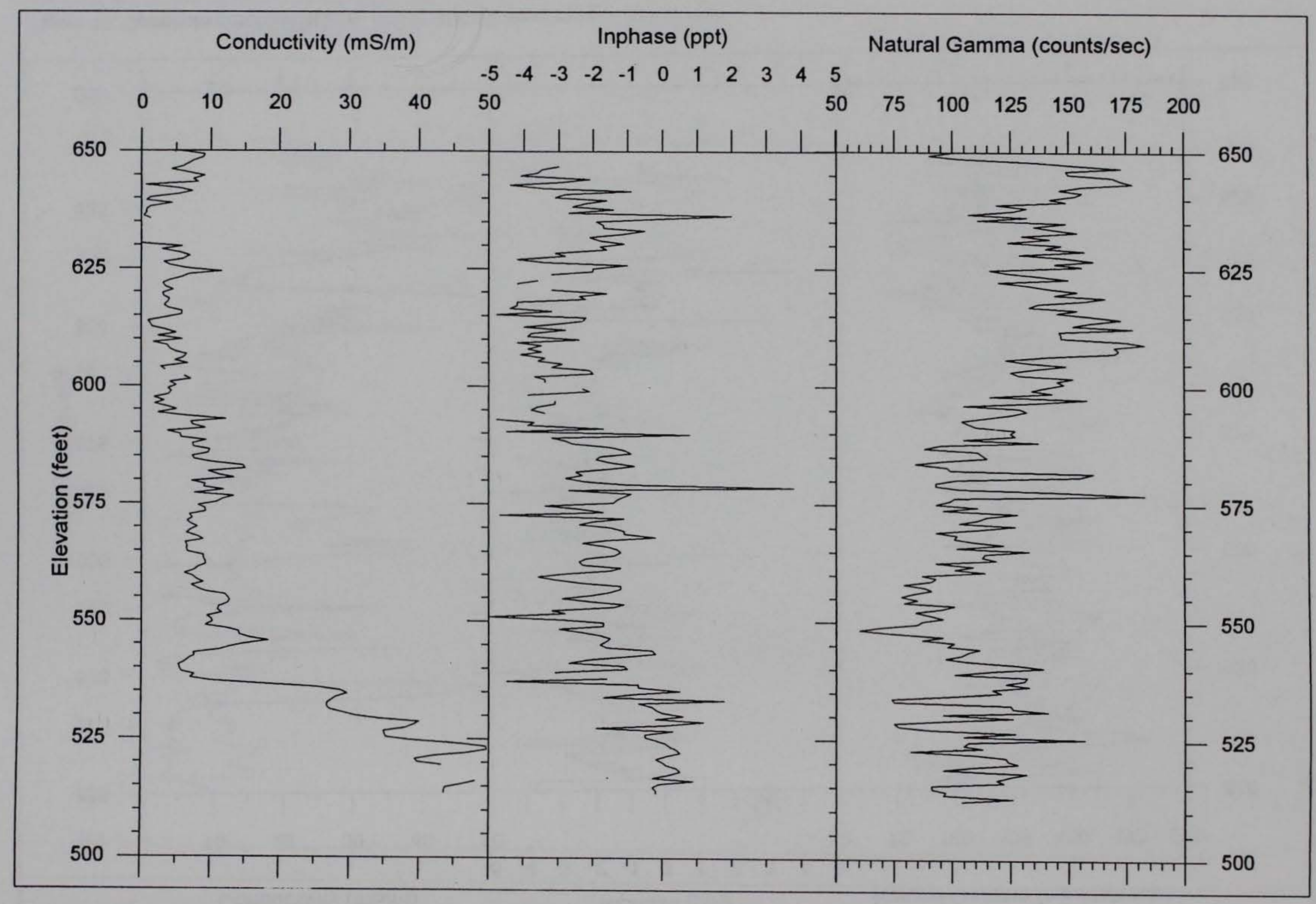

Figure 40. Downhole geophysical logs, boring GP04B, downstream service road 


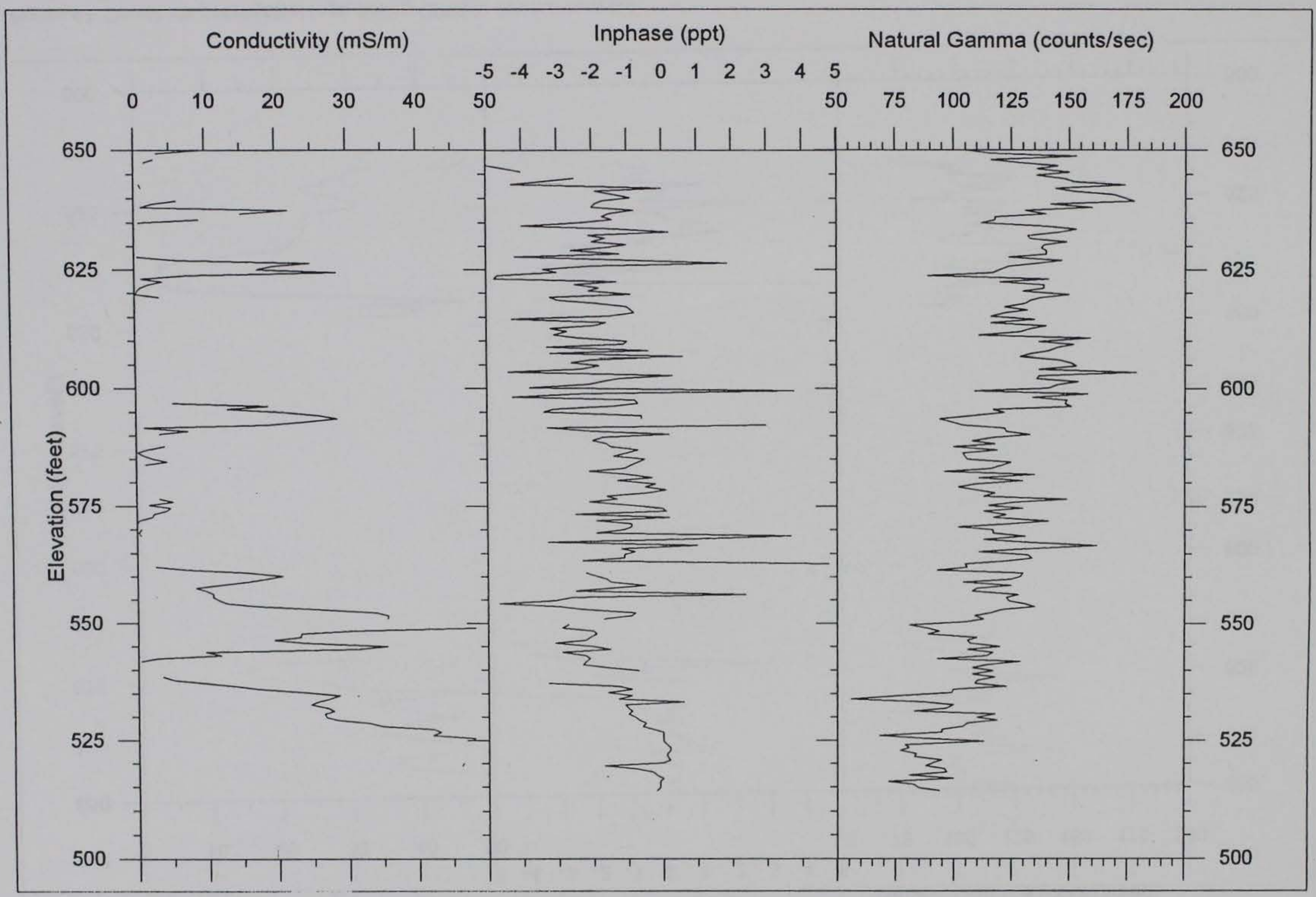

Figure 41. Downhole geophysical logs, boring GP04C, downstream service road 


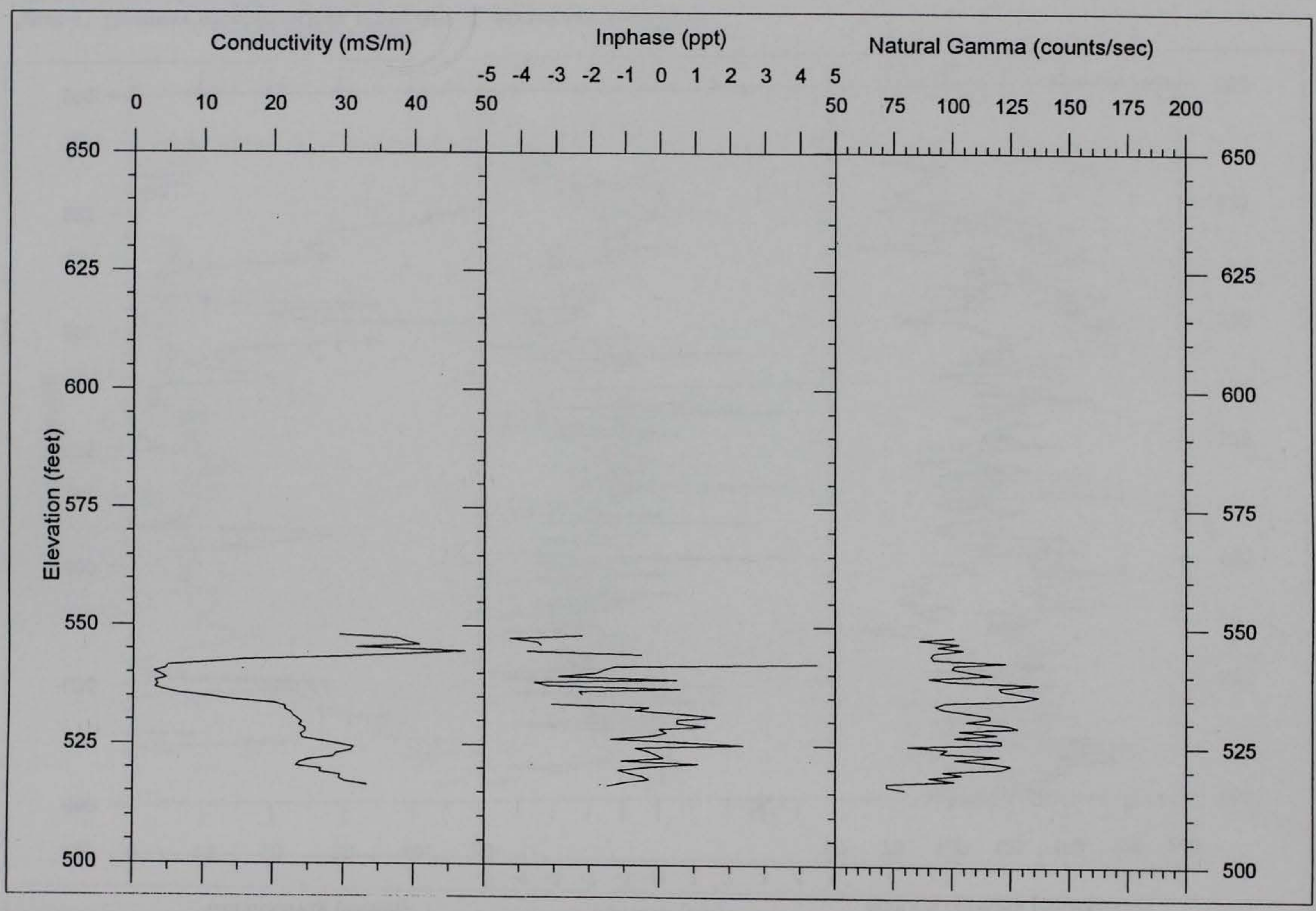

Figure 42. Downhole geophysical logs, boring GP05A, downstream toe 


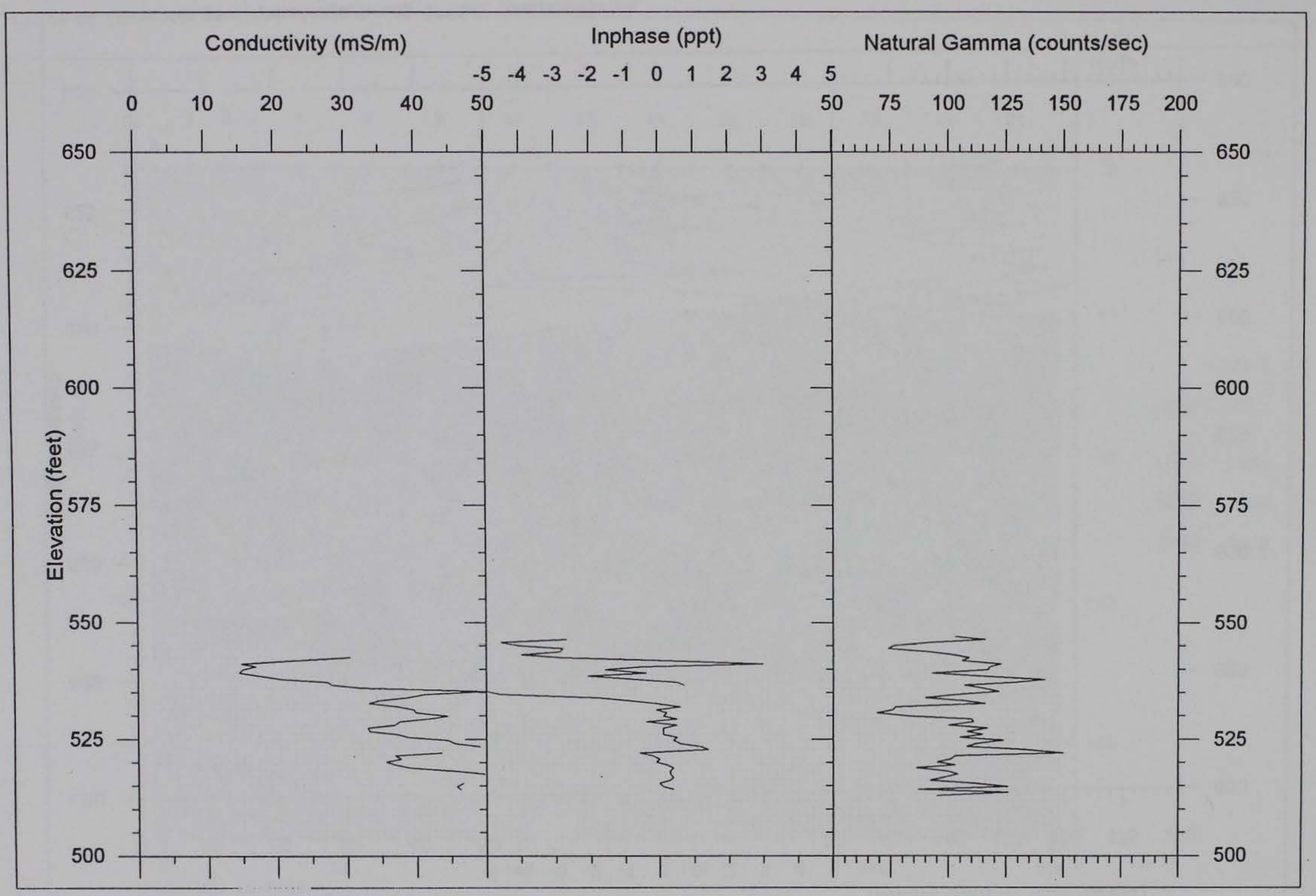

Figure 43. Downhole geophysical logs, boring GP05B, downstream toe 


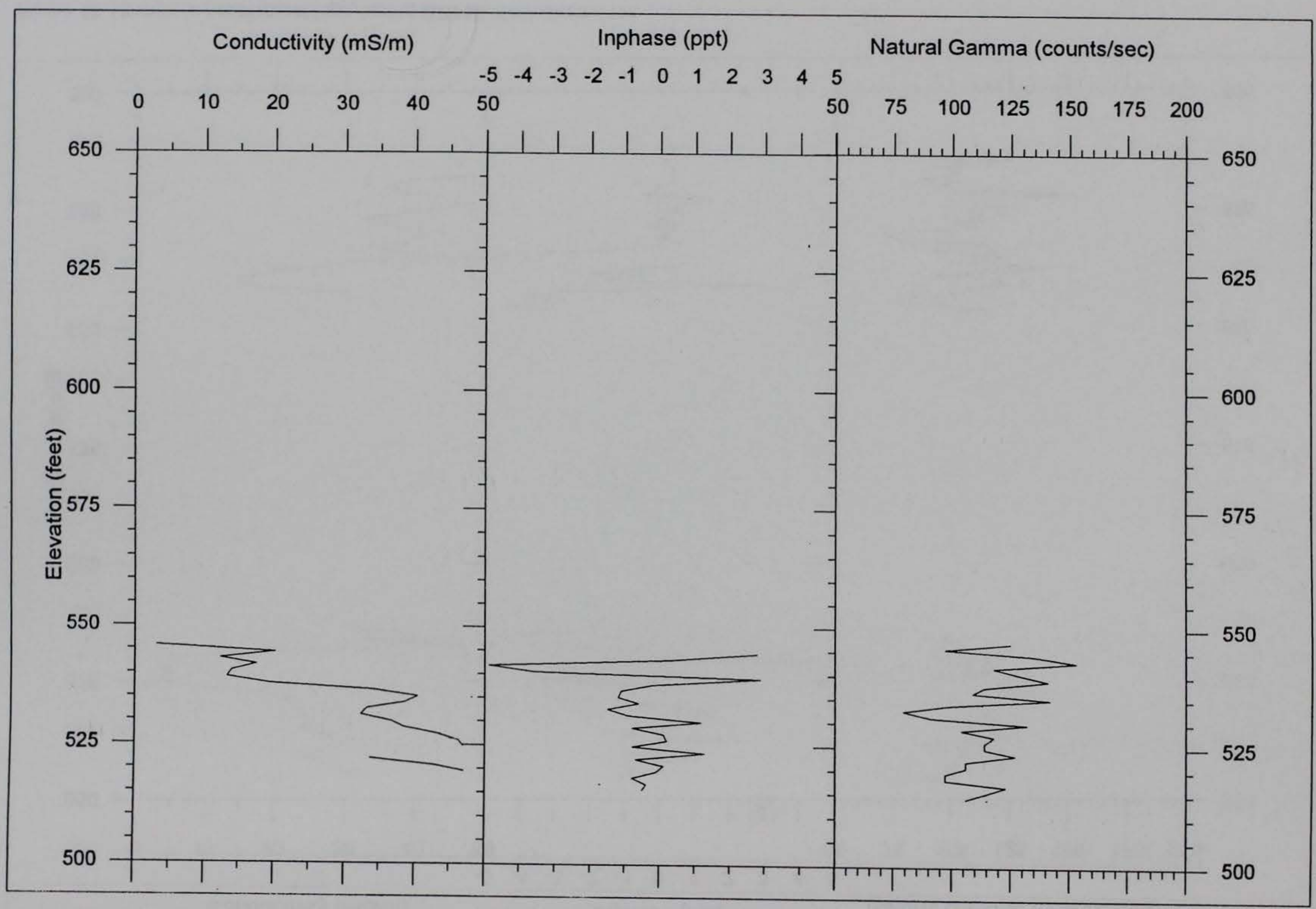

Figure 44. Downhole geophysical logs, boring GP05C, downstream toe 


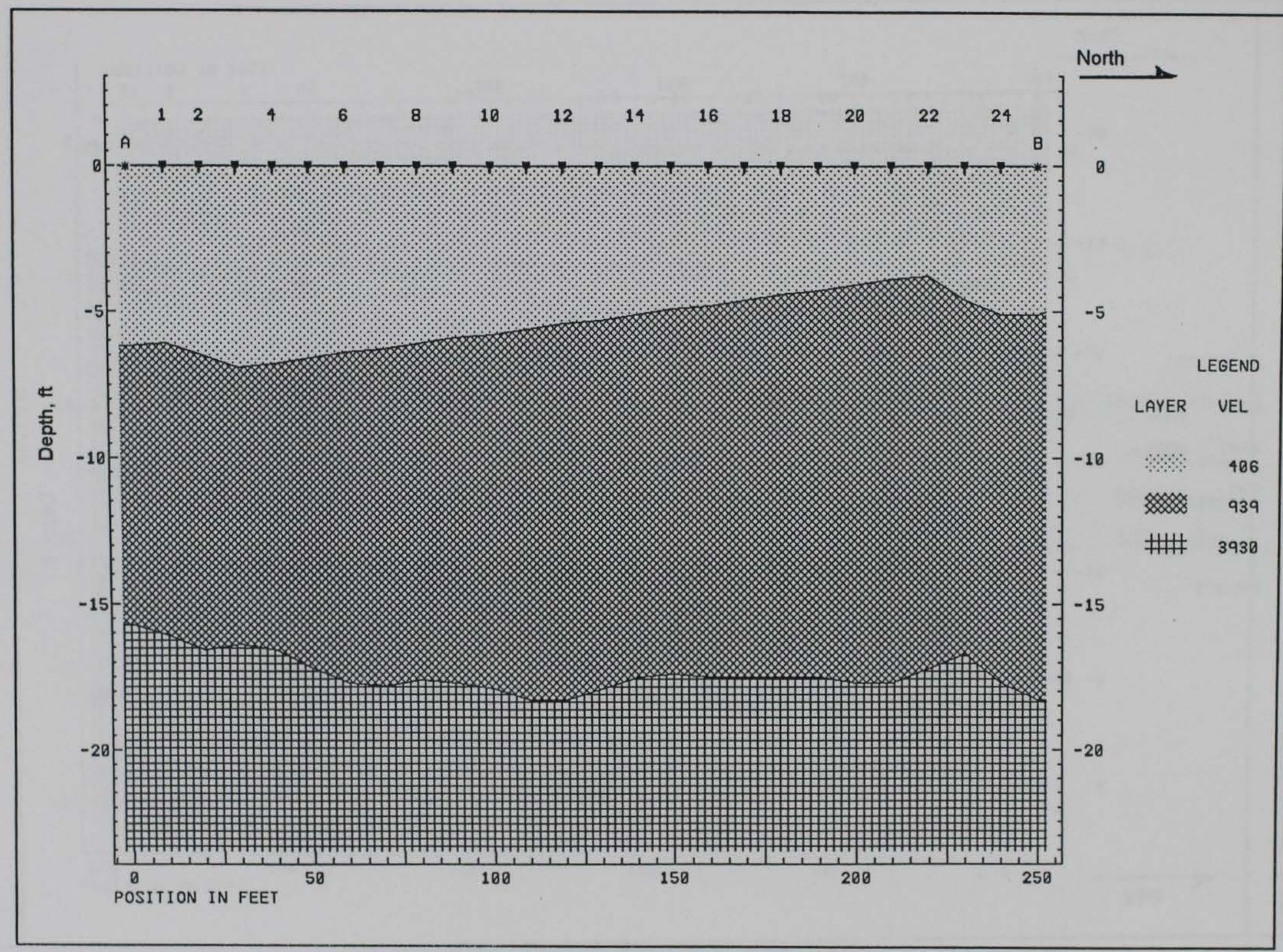

Figure 45. S-wave refraction line 1, downstream toe 


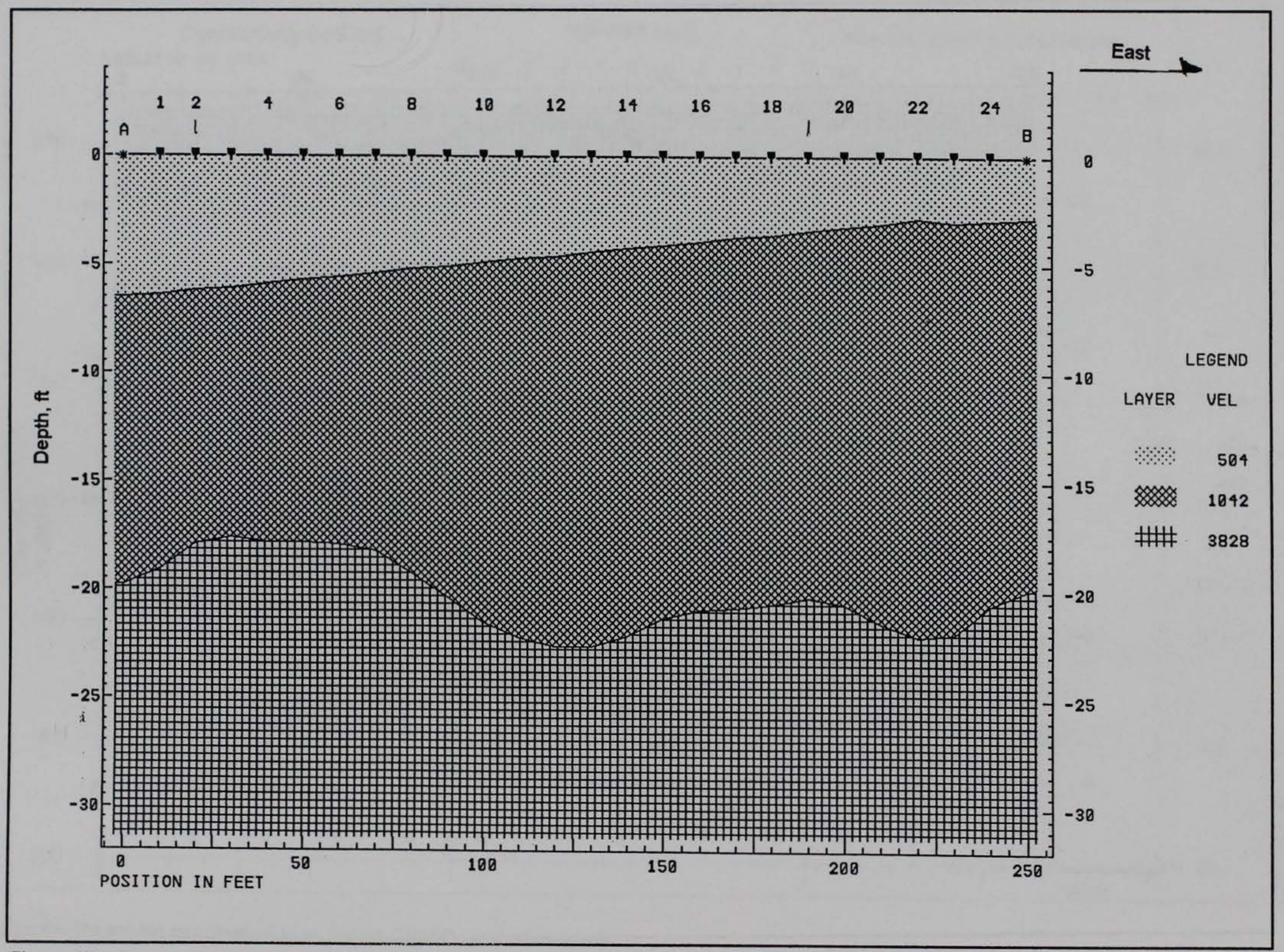

Figure 46. S-wave refraction line 2, downstream toe 


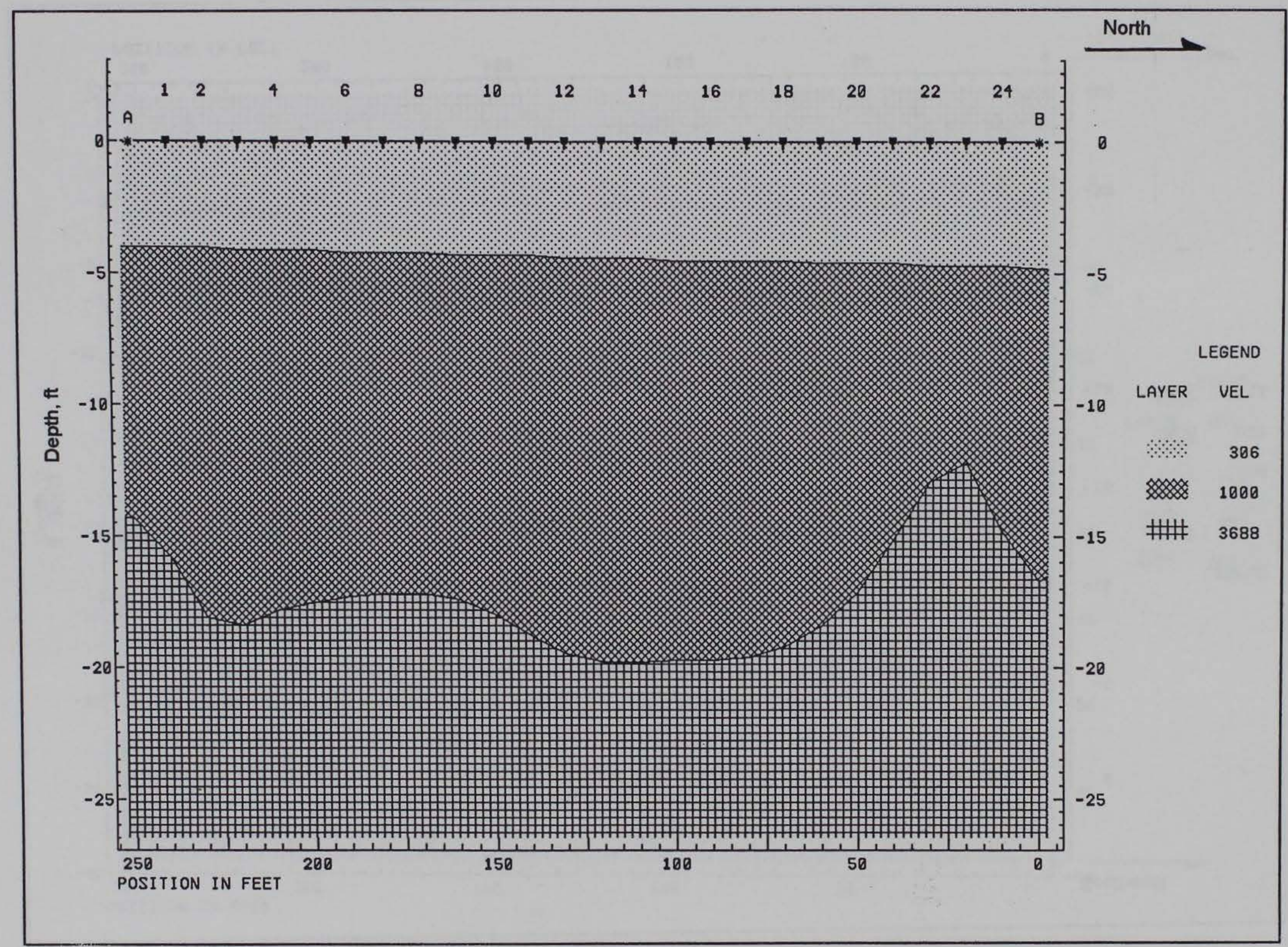

Figure 47. S-wave refraction line 3, downstream toe 


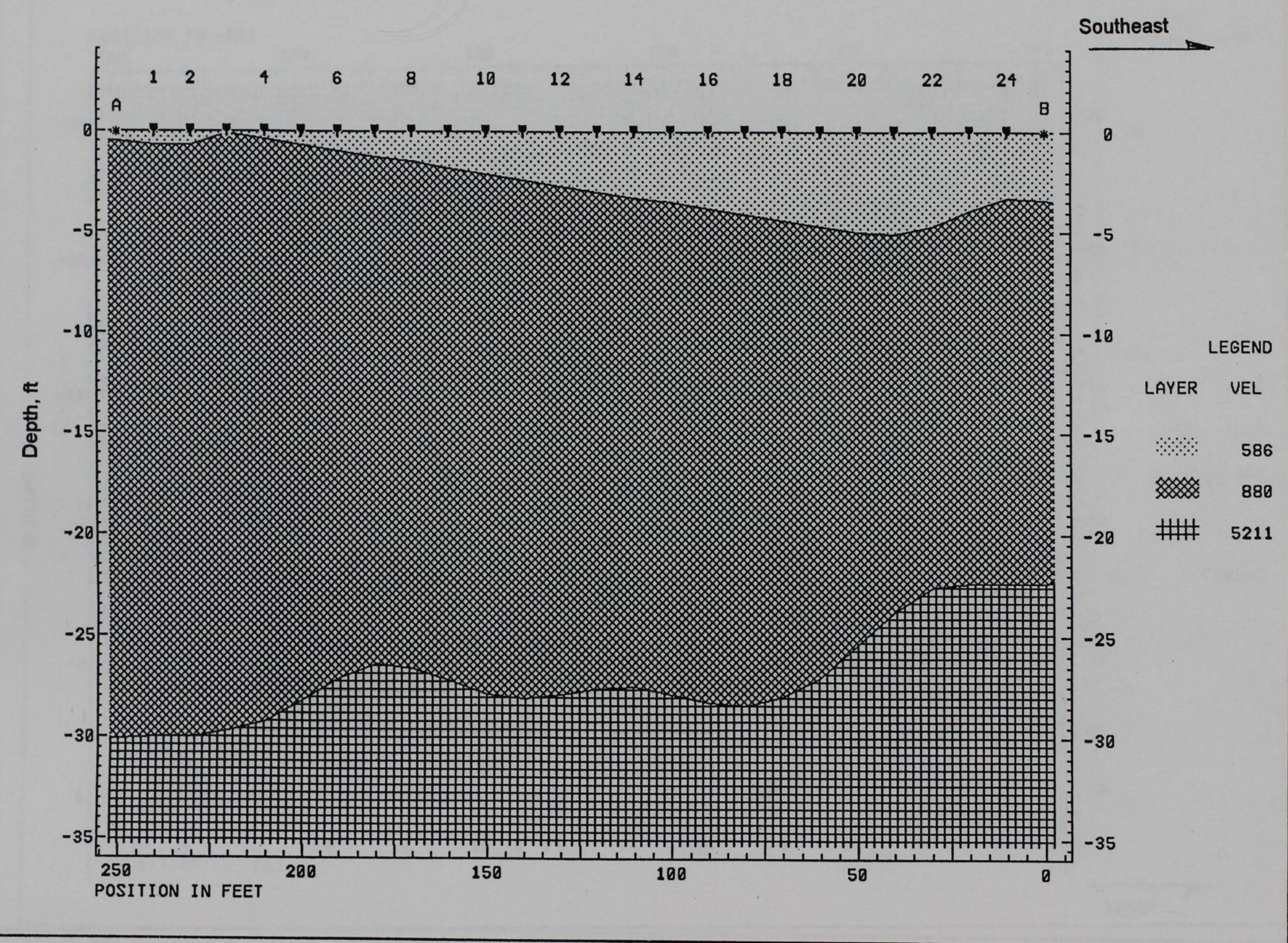

Figure 48. S-wave refraction line 4 , downstream toe 


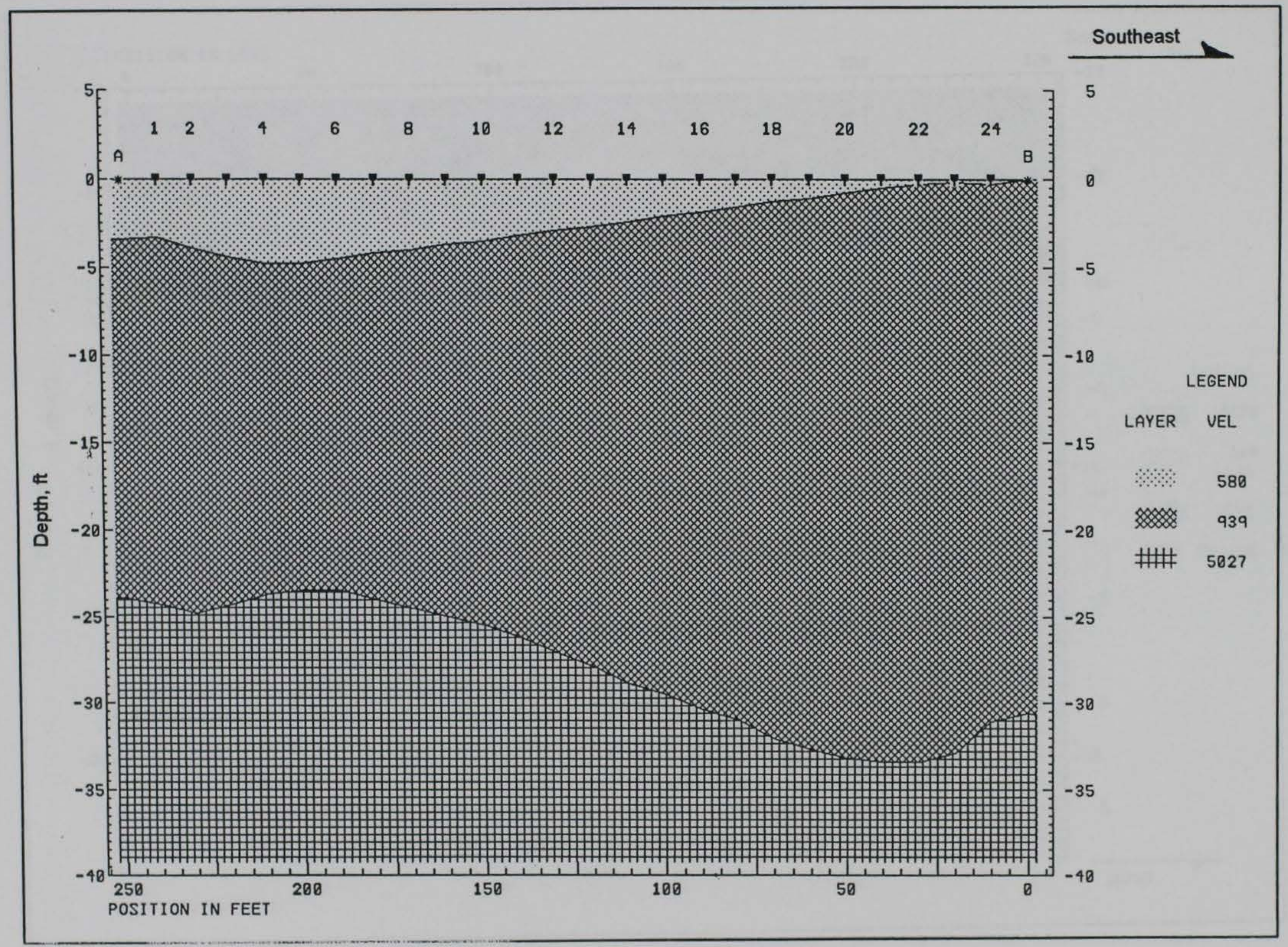

Figure 49. S-wave refraction line 5 , downstream toe 


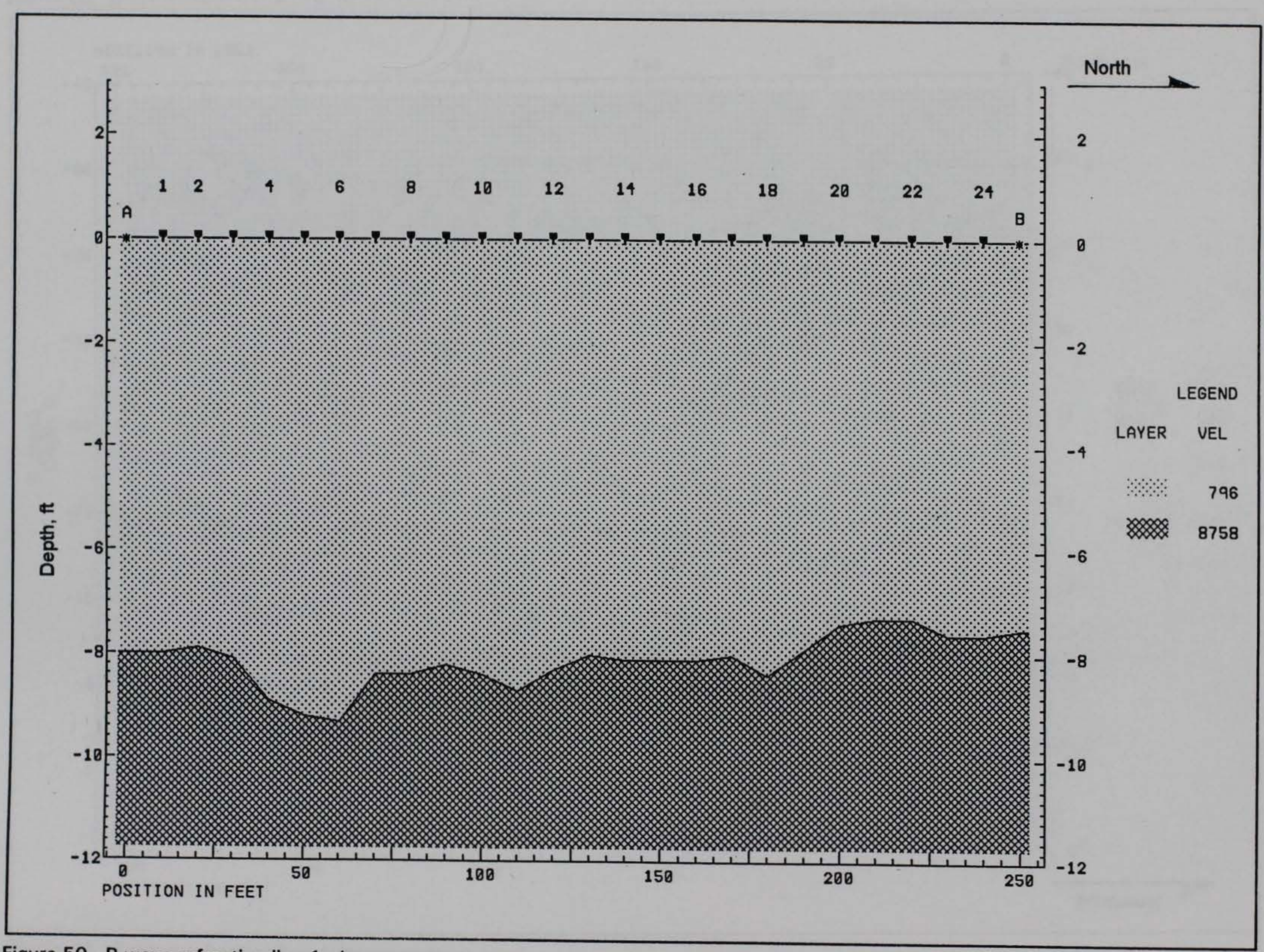

Figure 50. P-wave refraction line 1, downstream toe 


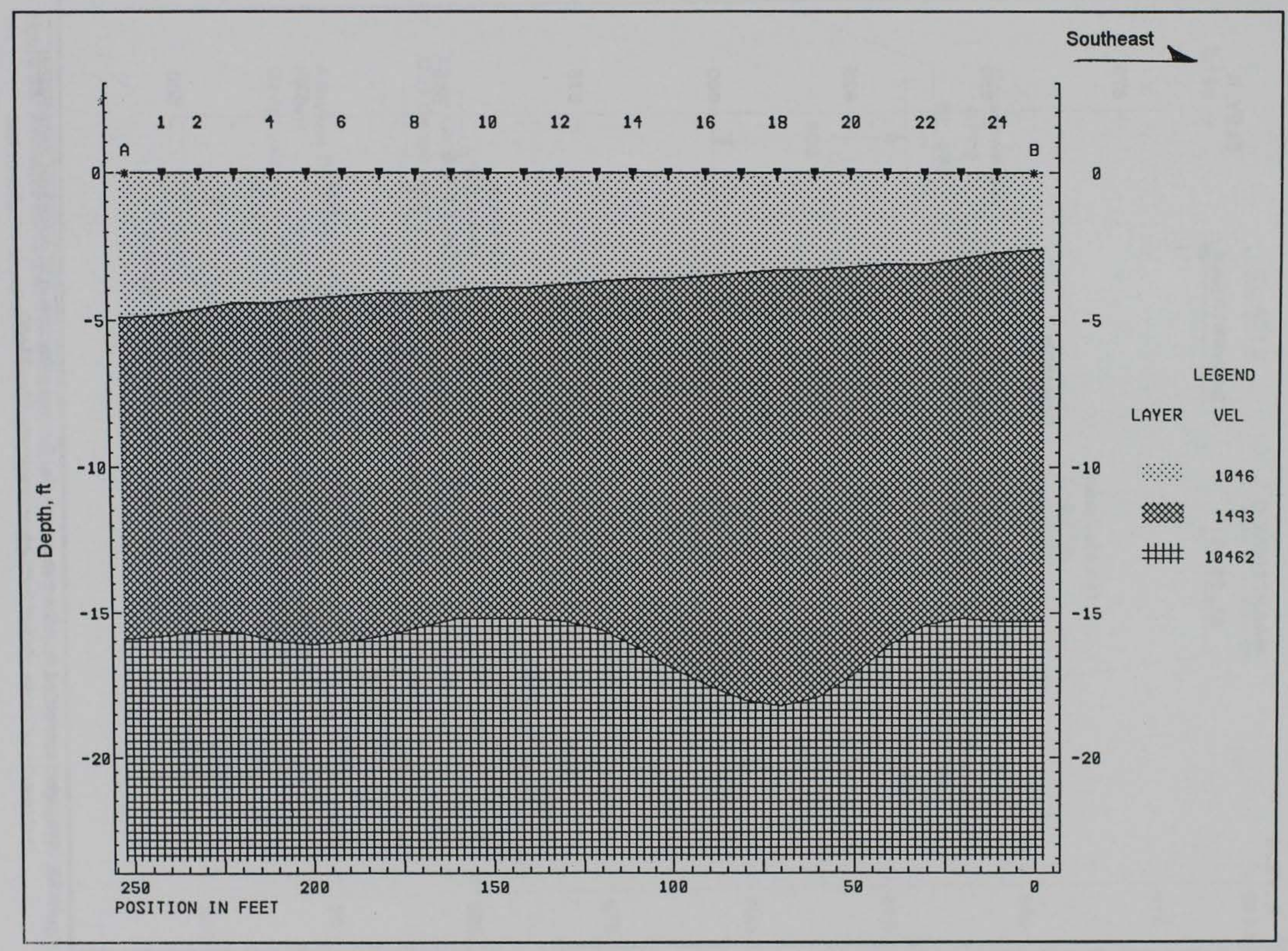

Figure 51. P-wave refraction line 4, downstream toe 


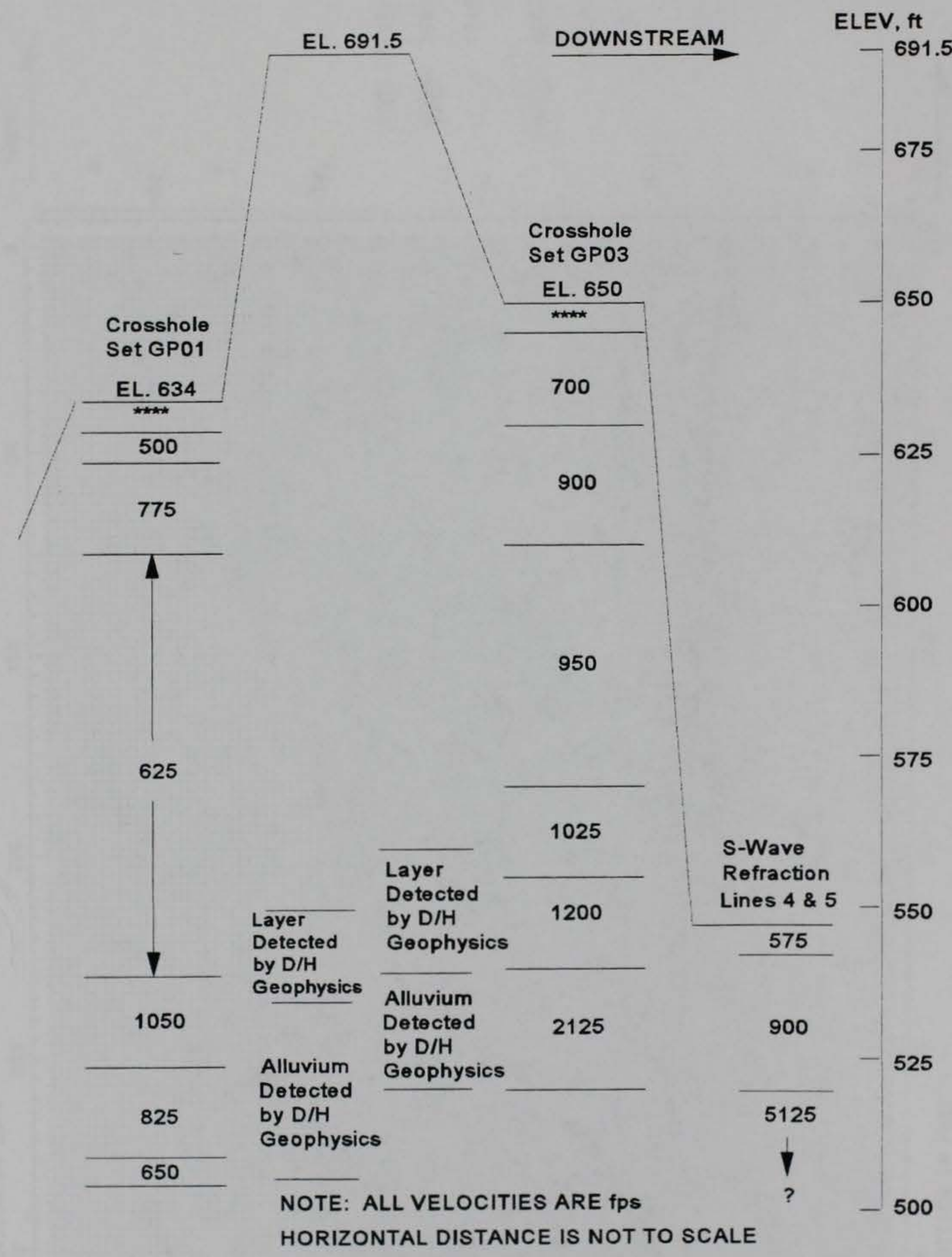

Figure 52. Averaged computed true S-wave crosshole, S-wave refraction, and downhole geophysical test results for cross section through approximate Sta. $28+80$ 


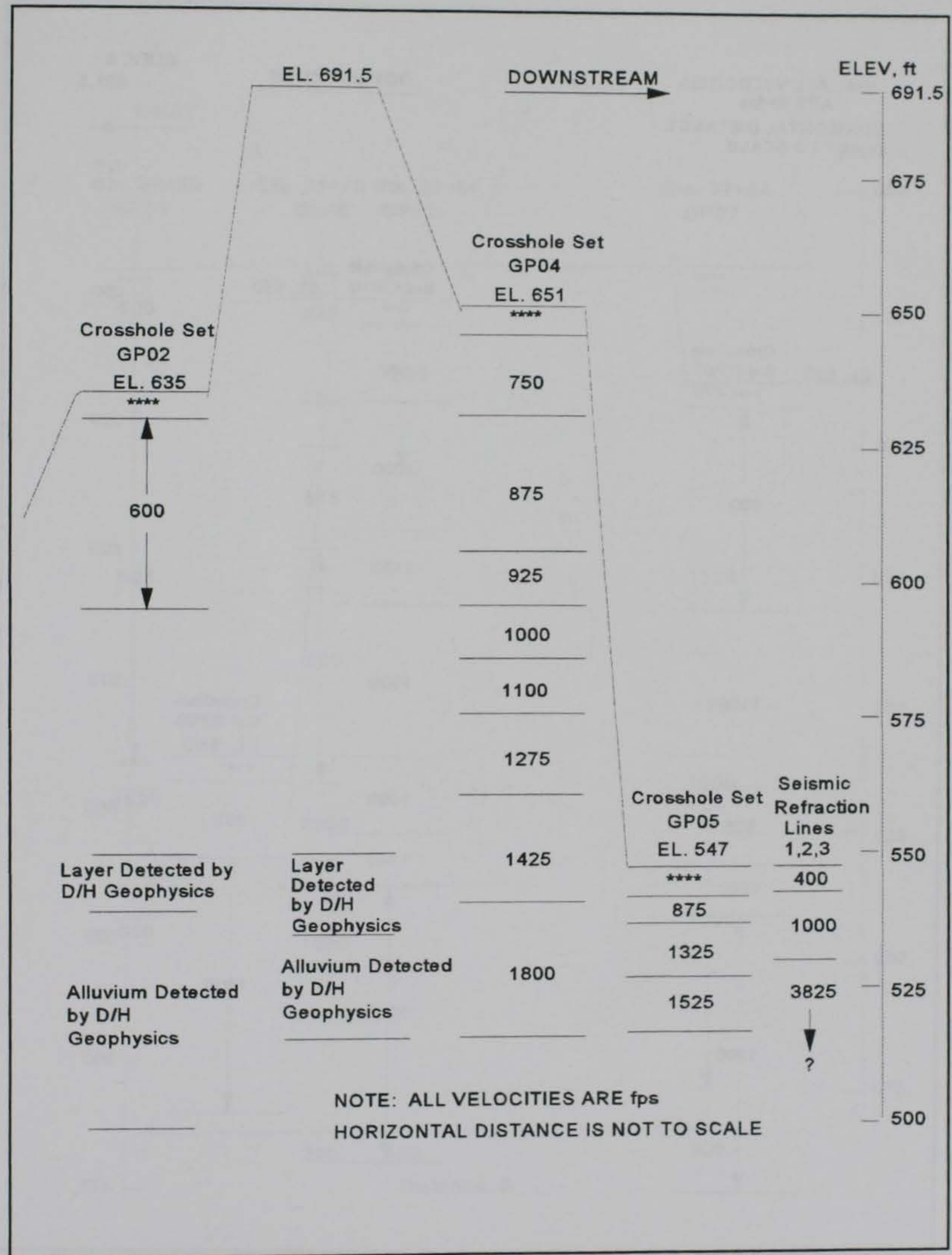

Figure 53. Averaged computed true S-wave crosshole, S-wave refraction, and downhole geophysical test results for cross section through approximate Sta. $33+20$ 


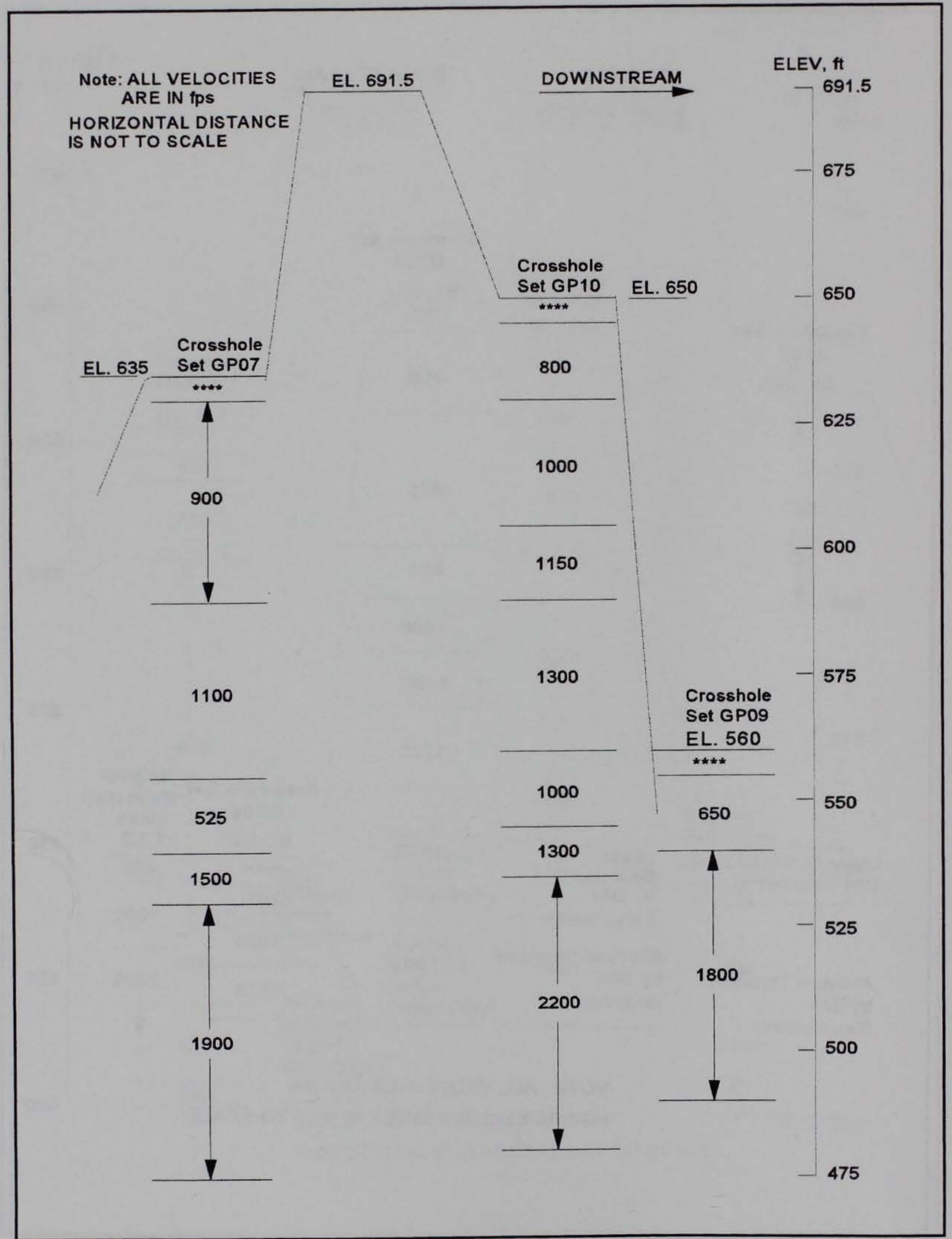

Figure 54. Averaged computed true S-wave crosshole and downhole geophysical test results for cross section through approximate Sta. $37+90$ 


\section{WEST}

ELEV, $\mathrm{ft}$

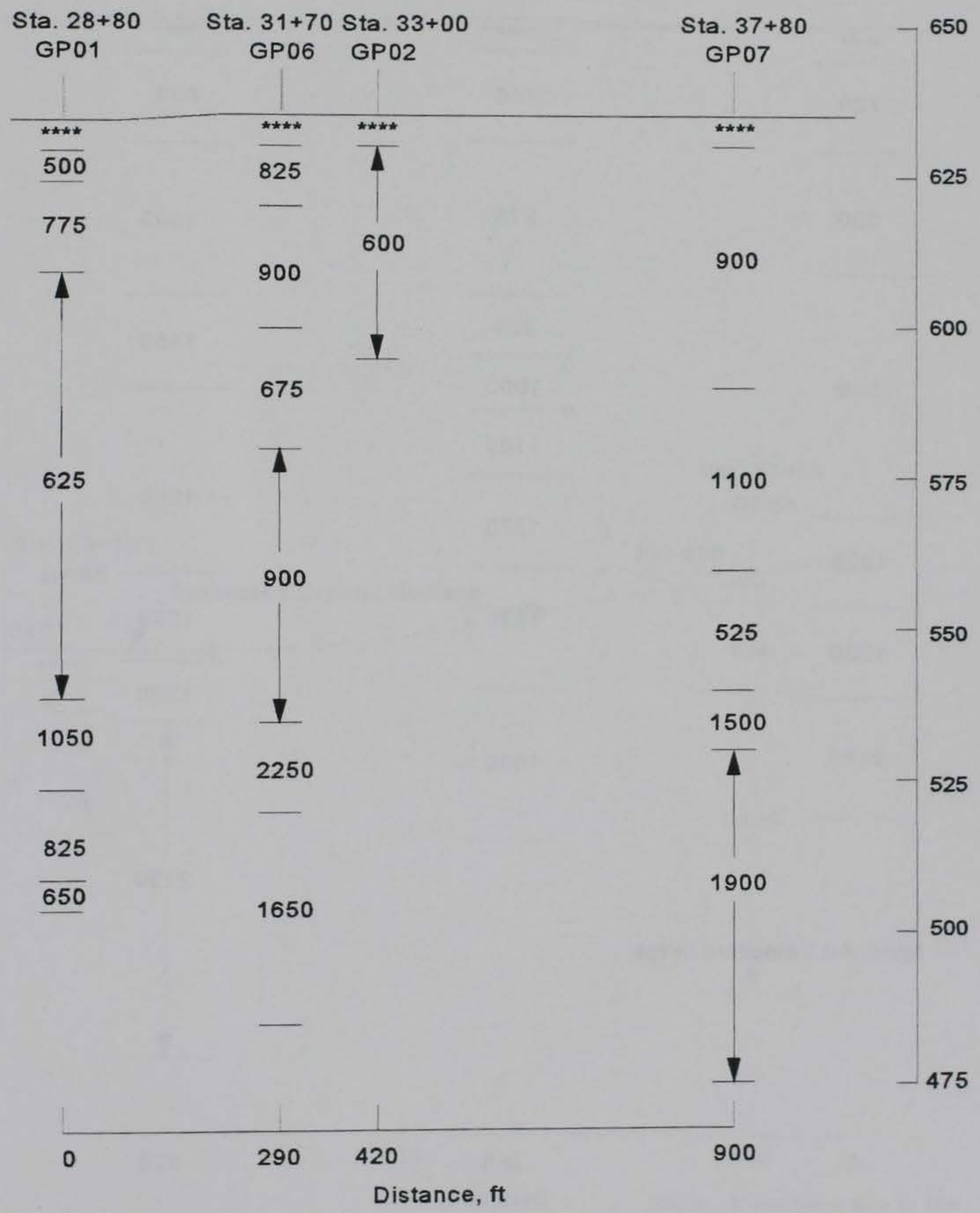

Figure 55. Averaged computed true S-wave crosshole velocities for longitudinal cross section along the upstream service road 


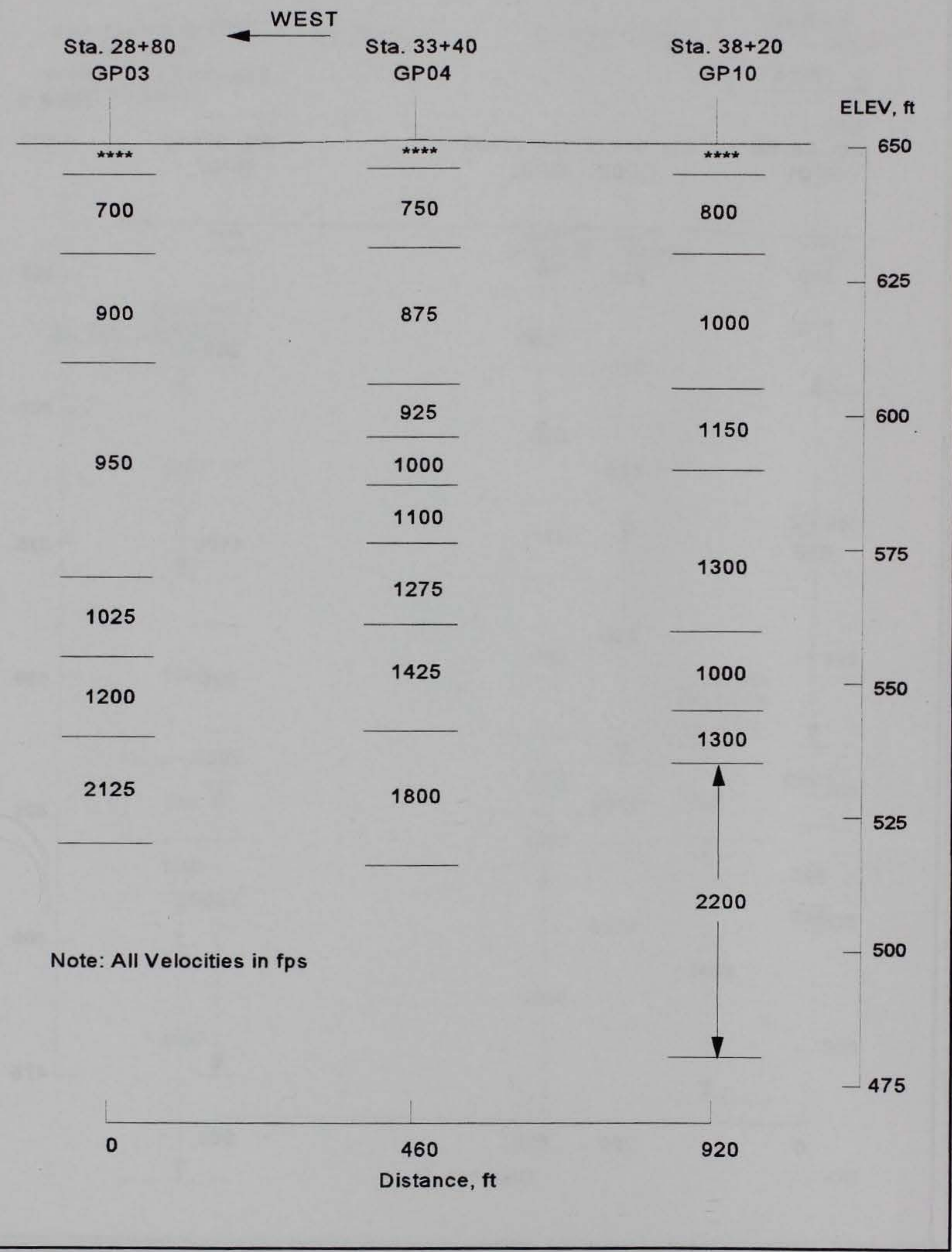

Figure 56. Averaged computed true S-wave crosshole velocities for longitudinal cross section along the downstream service road 


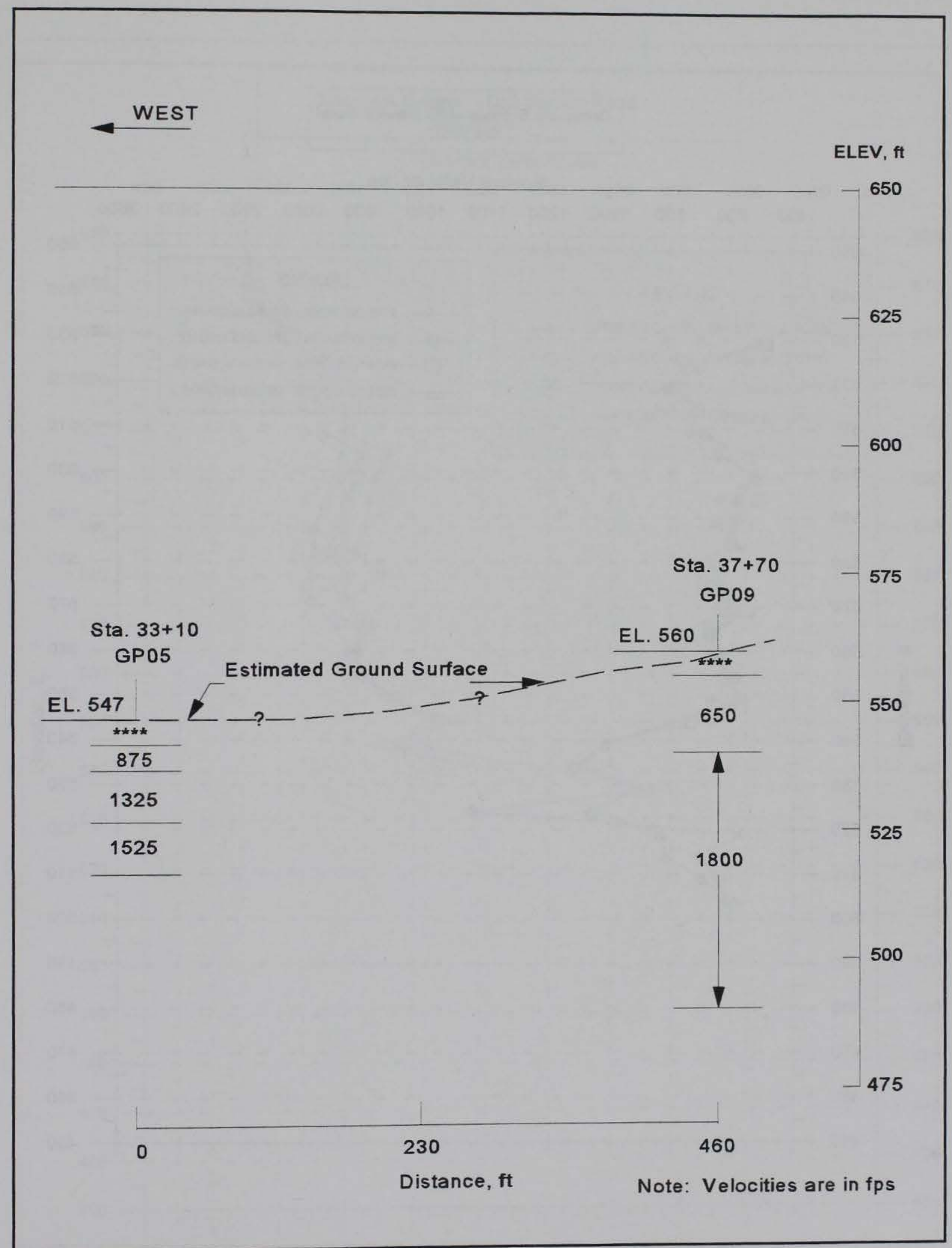

Figure 57. Averaged computed true S-wave crosshole velocities for longitudinal cross section along the downstream toe 


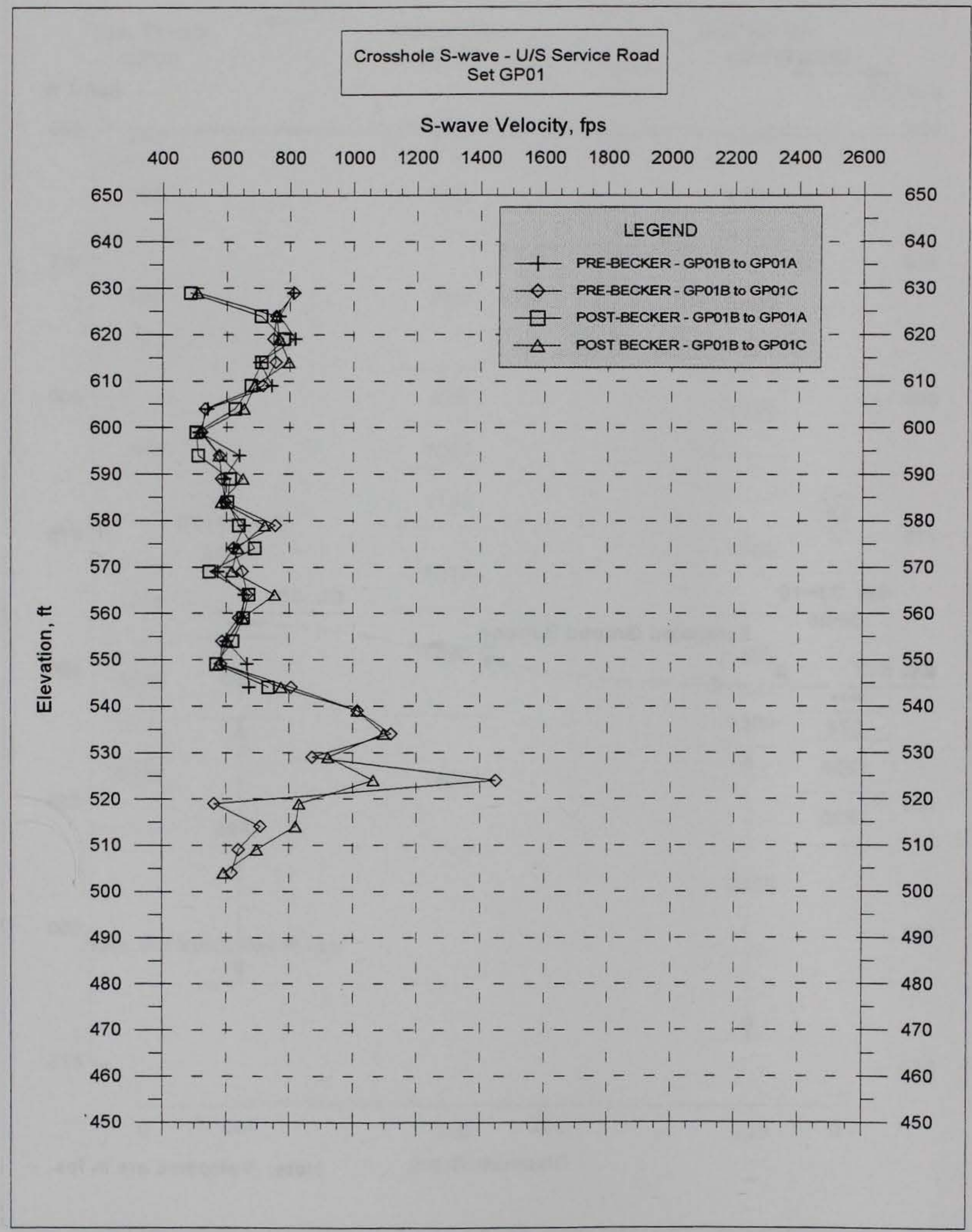

Figure 58. Pre- and post-Becker hammer drilling apparent crosshole S-wave velocities, boring set GP01, upstream service road, Sta. $28+80$ 


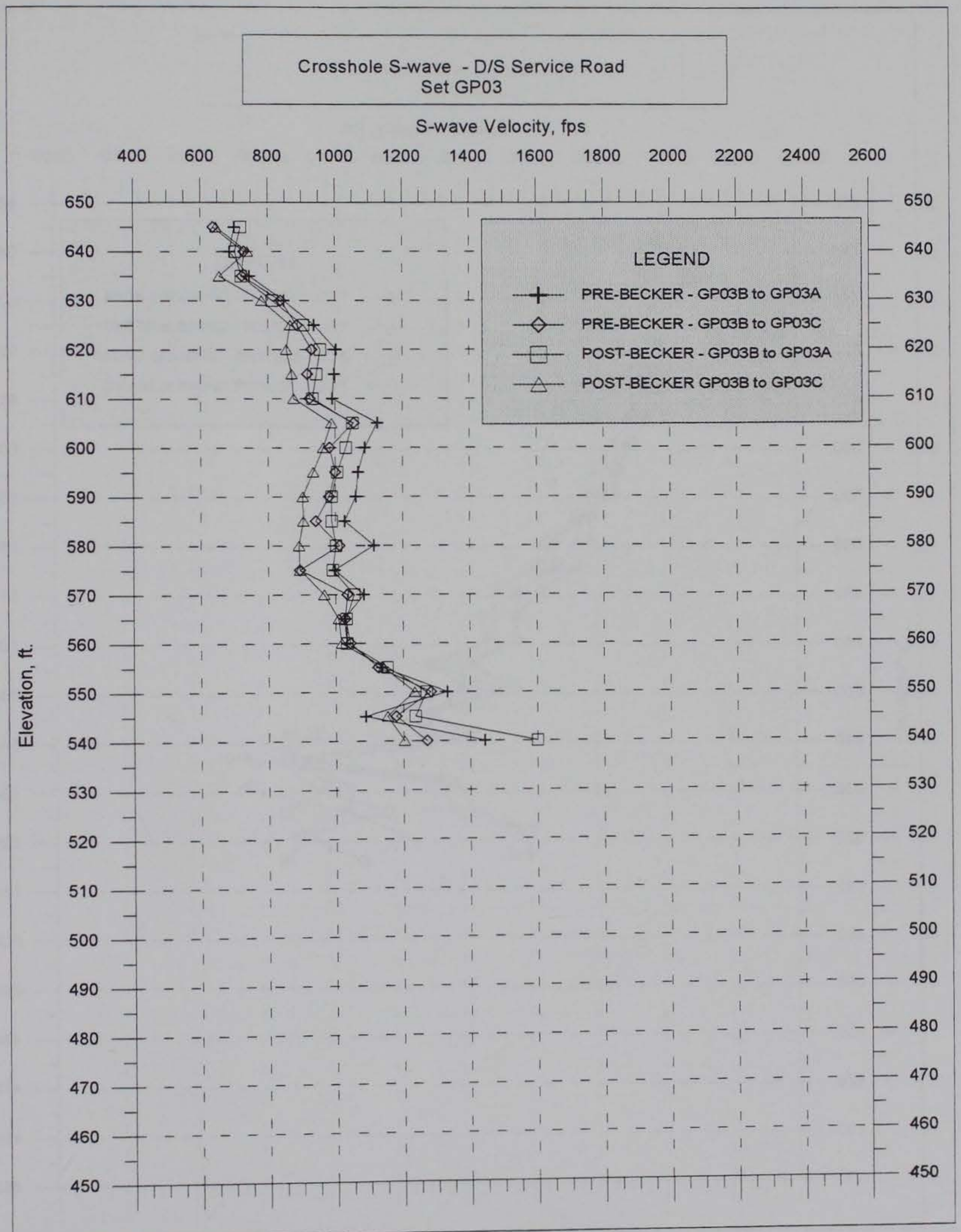

Figure 59. Pre- and post-Becker hammer drilling apparent crosshole S-wave velocities, boring set GP03, downstream service road, Sta. $28+80$ 


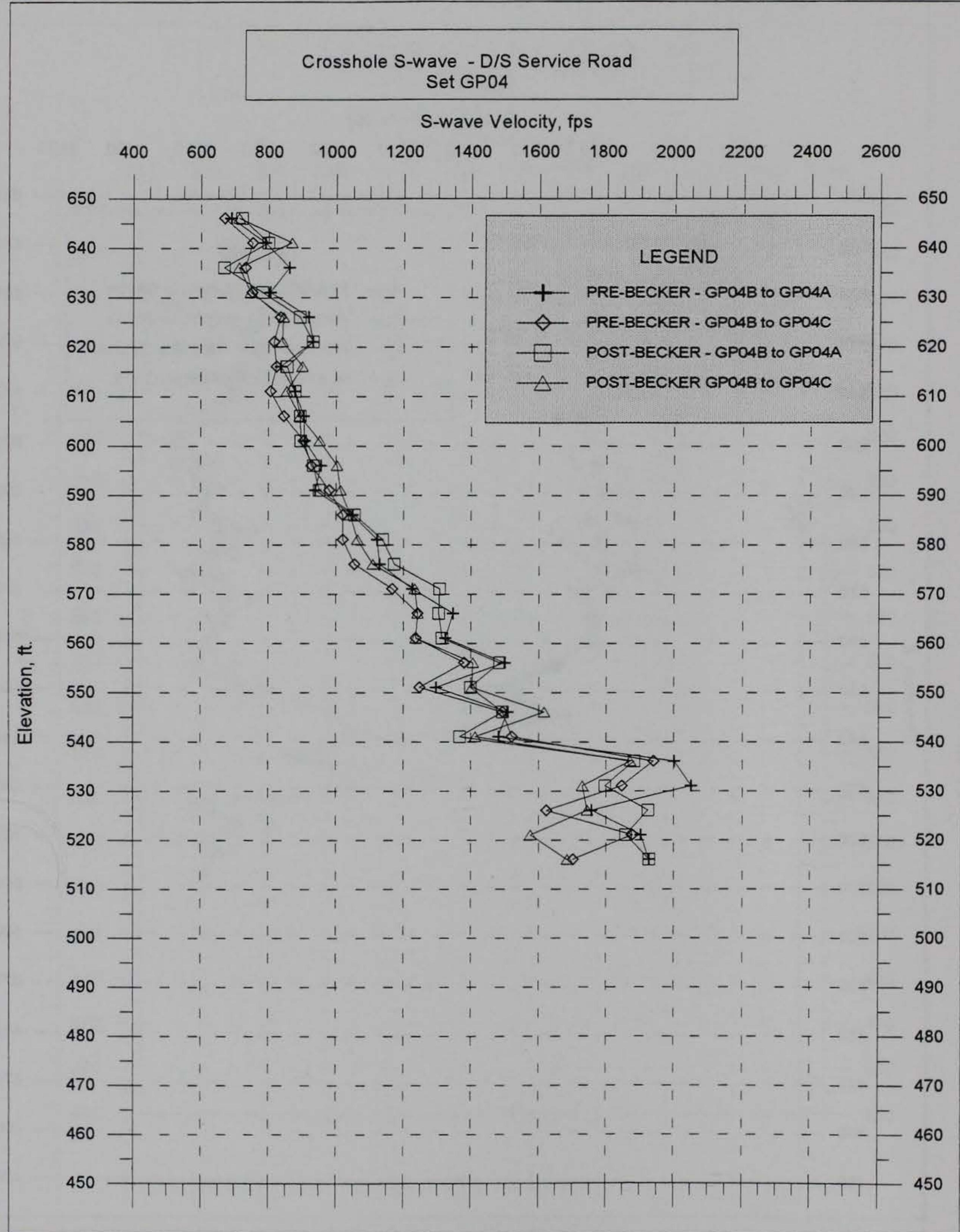

Figure 60. Pre- and post-Becker hammer drilling apparent crosshole S-wave velocities, boring set GP04, downstream service road, Sta. $33+40$ 


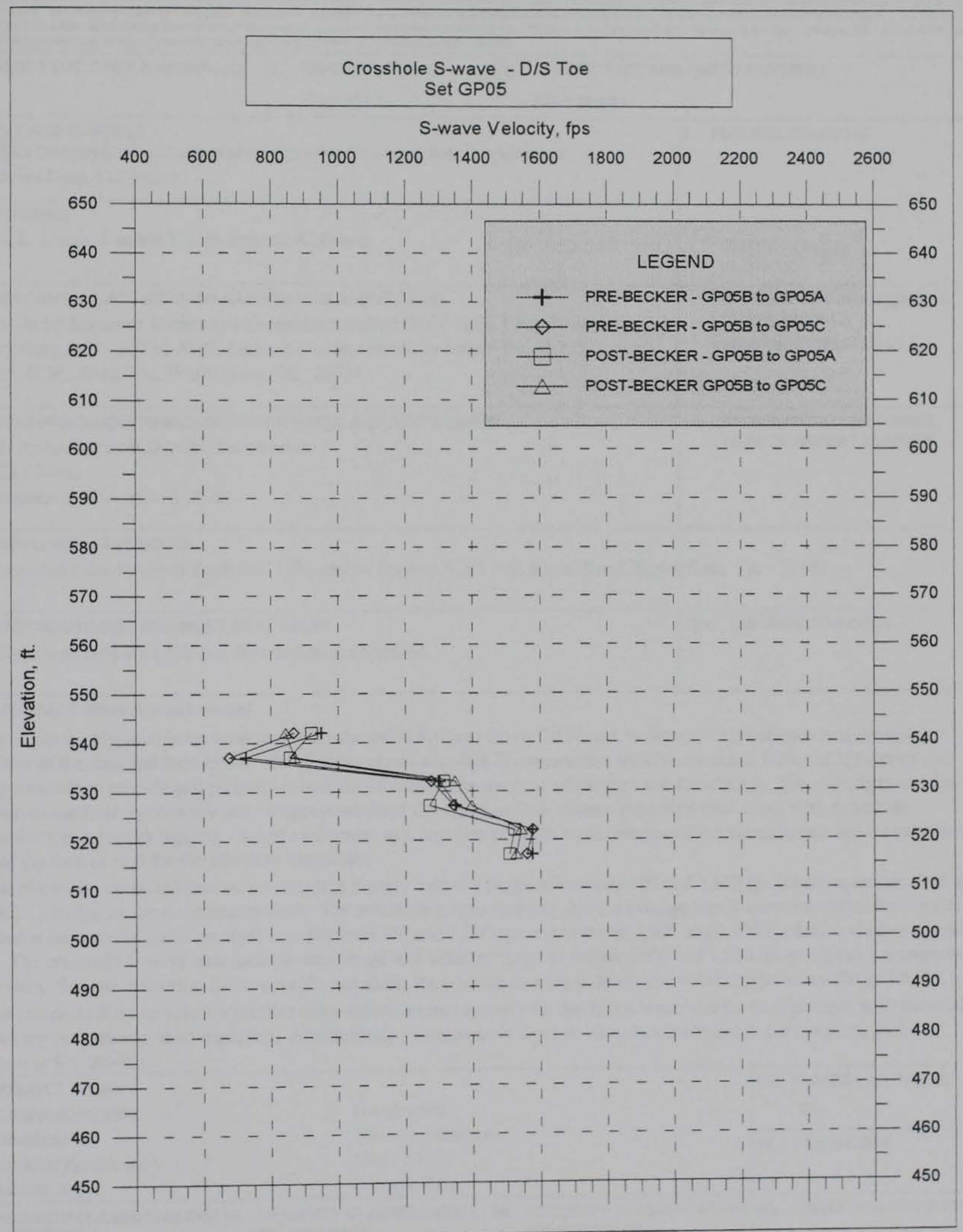

Figure 61. Pre-and post-Becker hammer drilling apparent crosshole S-wave velocities, boring set GP05, downstream toe, Sta. $33+10$ 


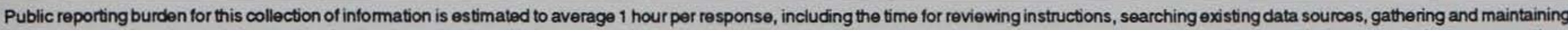

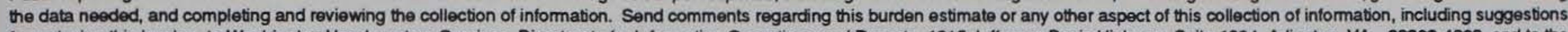

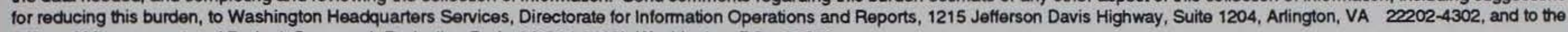
Office of Management and Budget, Paperwork Reduction Project (0704-0188), Washington, DC 20503.
1. AGENCY USE ONLY (Leave blank)
2. REPORT DATE
3. REPORT TYPE AND DATES COVERED

June 1997

Final report

4. TITLE AND SUBTITLE

In Situ Geophysical Investigation to Evaluate Dynamic Soil Properties at

5. FUNDING NUMBERS

Success Dam, California

6. AUTHOR(S)

José L. Llopis, Landris T. Lee, Russell A. Green

\section{PERFORMING ORGANIZATION NAME(S) AND ADDRESS(ES)}

U.S. Army Engineer Waterways Experiment Station, 3909 Halls Ferry Road,

Vicksburg, MS 39180-6199; Defense Nuclear Facilities Safety Board, 625 Indiana

Ave., N.W., Suite 700, Washington, DC 20004

8. PERFORMING ORGANIZATION REPORT NUMBER

Technical Report GL-97-8

10. SPONSORINGMONITORING AGENCY REPORT NUMBER

U.S. Army Engineer District, Sacramento

$1325 \mathrm{~J}$ Street

Sacramento, CA 95814-2922

\section{SUPPLEMENTARY NOTES}

Available from National Technical Information Service, 5285 Port Royal Road, Springfield, VA 22161.

\section{2a. DISTRIBUTION/AVAILABILITY STATEMENT}

12b. DISTRIBUTION CODE

Approved for public release; distribution is unlimited.

\section{ABSTRACT (Maximum 200 words)}

An in situ geophysical investigation was conducted at Success Dam, California, to determine the shear-wave (S-wave) velocities of the dam and foundation. The $S$-wave values are used in conjunction with conventional field and laboratory soil testing methods to provide soil property values for an earthquake analysis of the dam and foundation. The investigation consisted of S-wave crosshole and S-wave and compression-wave (P-wave) surface seismic refraction tests along with downhole conductivity and gamma logging. S-wave velocities as a function of depth were determined for the upstream and downstream shell of the dam as well for the alluvium foundation.

The crosshole results indicate an average true S-wave velocity range of between 500 and 1,100 fps for the upstream shell and 700 and 1,400 fps for the downstream shell. The crosshole results indicate that the average true $S$-wave velocities for the alluvium foundation beneath the upstream shell vary between 700 and 2,000 fps and between 1,800 and 2,200 fps below the downstream shell. The crosshole S-wave tests indicate an average true velocity range of between 650 and 1,750 fps along the downstream toe of the dam. Seismic refraction S-wave results run along the downstream toe indicate true velocities between 400 and $5,125 \mathrm{fps}$.

The crosshole S-wave velocity profiles show velocities increasing with depth at a lower rate for the upstream shell materials than for the downstream shell materials. Anomalously low crosshole S-wave velocities are found in the upstream shell and alluvium at Sta. $28+80$.

$$
\begin{array}{|l}
\hline \text { 14. } \\
\text { SUBJECT TERMS } \\
\text { Compression wav } \\
\text { Crosshole } \\
\text { Electromagnetic } \\
\text { Gamma logs } \\
\hline \text { 17. SECURITY CLASS } \\
\text { OF REPORT } \\
\text { UNCLASSIFIED } \\
\hline \text { NSN 7540-01-280-5500 }
\end{array}
$$

Compression wave

Crosshole

Electromagnetic logs

Gamma logs

Geophysics
Seismic refraction
Shear wave
Success Dam

15. NUMBER OF PAGES 98

16. PRICE CODE

\section{SECURITY CLASSIFICATION} OF REPORT

UNCLASSIFIED
18. SECURITY CLASSIFICATION OF THIS PAGE

UNCLASSIFIED 